\title{
PATOSSISTEMA MILHO X Colletotrichum graminicola: ESTUDO DE HERANÇA, MAPEAMENTO DE GENES DE RESISTÊNCIA E ESTIMATIVAS DE DANOS NA PRODUÇÃO
}

\author{
RODRIGO RODRIGUES MATIELLO
}

Tese apresentada à Escola Superior de Agricultura "Luiz de Queiroz", Universidade de São Paulo, para obtenção do título de Doutor em Agronomia, Área de Concentração: Genética e Melhoramento de Plantas.

PIR A C I C A B A

Estado de São Paulo - Brasil

Janeiro - 2004 


\title{
PATOSSISTEMA MILHO X Colletotrichum graminicola: ESTUDO DE HERANÇA, MAPEAMENTO DE GENES DE RESISTÊNCIA E ESTIMATIVAS DE DANOS NA PRODUÇÃO
}

\author{
RODRIGO RODRIGUES MATIELLO
}

Engenheiro Agrônomo

Orientador: Prof. Dr. LUIS EDUARDO ARANHA CAMARGO

Tese apresentada à Escola Superior de Agricultura "Luiz de Queiroz", Universidade de São Paulo, para obtenção do título de Doutor em Agronomia, Área de Concentração: Genética e Melhoramento de Plantas.

PIR A C I C A B A

Estado de São Paulo - Brasil

Janeiro - 2004 
Dados Internacionais de Catalogação na Publicação (CIP) DIVISÃO DE BIBLIOTECA E DOCUMENTAÇÃO - ESALQ/USP

Matiello, Rodrigo Rodrigues

Patossistema milho X Colletotrichum graminicola : estudo de herança, mapeamento de genes de resistência e estimativas de danos na produção / Rodrigo Rodrigues Matiello. - - Piracicaba, 2004.

116 p. : il.

Tese (doutorado) - Escola Superior de Agricultura Luiz de Queiroz, 2004.

Bibliografia.

1. Antracnose 2. Mapeamento genético 3. Marcador molecular 4. Milho 
A minha esposa: Mara Cristina

de Almeida Matiello por nosso

amor. Obrigado por sua

existência.

Dedico

A meus pais: João Matiello e Morena

Rodrigues Matiello e meus irmãos:

Márcia, Maristela e Valmor. Pelo

apoio e compreensão.

Ofereço 


\section{AGRADECIMENTOS}

A Deus pela energia positiva ao longo destes anos.

Ao Prof. Dr. Luis Eduardo Aranha Camargo pela orientação efetiva, responsabilidade científica e profissionalismo acadêmico. Obrigado pela oportunidade e crescimento profissional.

Aos professores do Departamento de Genética da ESALQ-USP pelos conhecimentos transmitidos e pelas sugestões neste trabalho.

Aos professores do Departamento de Fitopatologia da ESALQ-USP pela oportunidade de aprendizagem e por disponibilizar seus laboratórios para a realização deste trabalho.

À Prof. Dra. Mara Cristina de Almeida Matiello, pela efetiva contribuição acadêmica-científica em todas as etapas deste trabalho. Além disto, pela paciência, carinho e compreensão nas horas difíceis.

Agradeço a meus pais João Matiello e Morena Rodrigues Matiello e meus irmãos Márcia, Maristela e Valmor pelo apoio, carinho e compreensão neste período.

A minha segunda família Jurandir Paulo de Almeida, Maria Zita Marins Freire de Almeida e Andréia pela acolhida, carinho e dedicação nestes anos.

Aos amigos e colegas de Pós-Graduação Ana Paula, Kátia, Maria Teresa, Ana Carolina, Ivan e Mateus pela ajuda na coleta dos dados e pelo companheirismo durante estes quatro anos. 
Aos colegas do Laboratório de Genética Molecular do Departamento de Fitopatologia Daniela, Célia, Maria Teresa, Mariana, Kátia, Viviane, Ana Paula, Patrícia, Adriana, Alessandra, Paulo, Ana Carolina, Regina, Cláudia, Jorge, Herberte, Flávia, Maeli, Alice, Giovana, Maria Cristina, Osmar, Camila, Marcelo, Alessandra, Raphaelle, Ademir, Thayne, Juliana e Mariana pela verdadeira amizade, convívio e crescimento profissional.

Aos colegas do curso de pós-graduação em Genética e Melhoramento de Plantas pela amizade e atenção.

Aos funcionários do Departamento de Genética Léia, Maidia, Macedônio e Neuza pela ajuda e disponibilidade ao serem solicitados.

Aos funcionários do Departamento de Fitopatologia Maria Heloisa, Fernanda, Rodolfo, Marina, Jefferson, Sr. Pedro, Marisa, Sílvia e Edivaldo pela disponibilidade, ensinamentos e pela amizade.

À bibliotecária Maria da Glória Eloi da Silva pela revisão geral da tese.

A Universidade Estadual de Ponta Grossa em especial aos colegas do Departamento de Fitotecnia e Fitossanidade pela oportunidade de treinamento.

Aos colegas professores David, Maristela, Raulindo, Cláudio e Mariê pelo incentivo, ajuda e amizade.

As secretárias da Pró-Reitoria de Pesquisa e Pós-Graduação da UEPG Márcia, Vera e Soely pela disponibilidade e ajuda neste período.

A Empresa de Sementes DowAgroSciences Ltda. por disponibilizar o material vegetal para este trabalho.

À CAPES-PICDT pela concessão da bolsa de estudo.

À FAPESP pelo auxílio financeiro a esta pesquisa. 


\section{SUMÁRIO}

Página

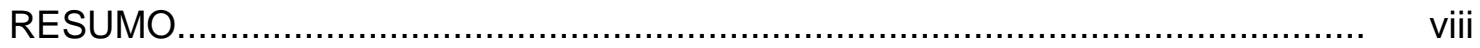

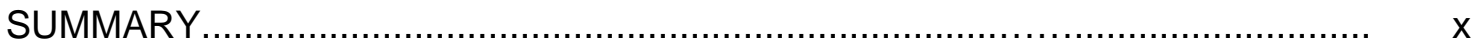

1 INTRODUÇÃ

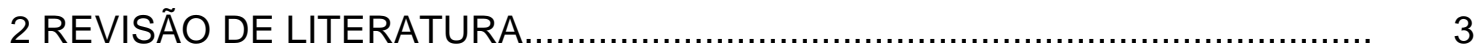

2.1 Podridões de colmo em milho............................................................... 3

2.2 Patossistema milho x C. graminicola ...................................................... 4

2.3 Genética da resistência a $C$. graminicola................................................ 6

2.4 Marcadores moleculares e mapeamento genético......................................... 7

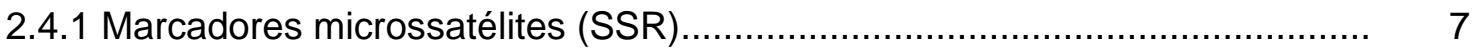

2.4.2 Marcadores AFLPs.................................................................... 8

2.4.3 Mapeamento genético usando marcadores moleculares.......................... 10

3 HERANÇA DA RESISTÊNCIA À ANTRACNOSE DO COLMO

(Colletotrichum graminicola Ces. Wils) EM LINHAGENS

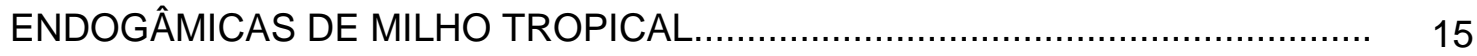

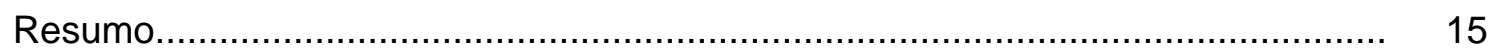

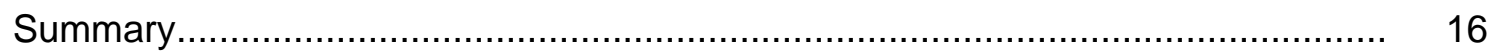

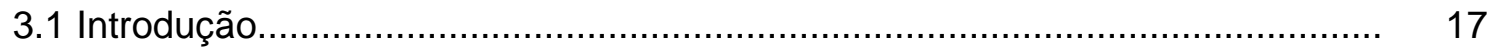

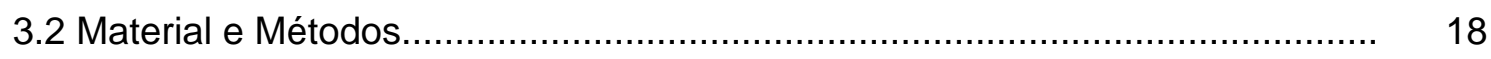

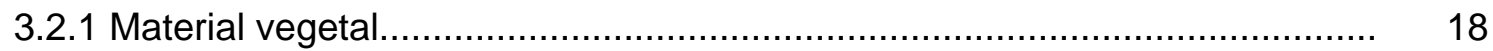

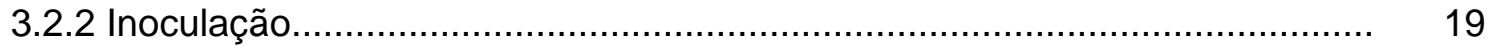

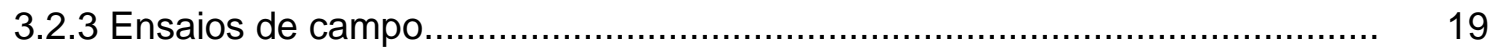

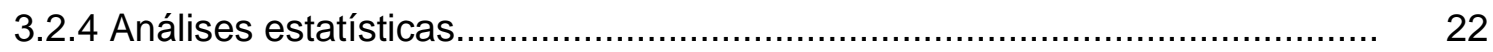

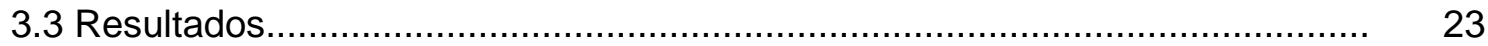

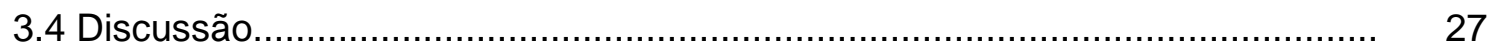

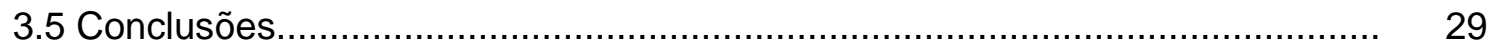


4 MAPEAMENTO GENÉTICO DE GENES DE RESISTÊNCIA À ANTRACNOSE DO COLMO EM MILHO CAUSADA POR Colletotrichum graminicola (Ces.) Wils

Resumo.

Summary.

4.1 Introdução.

4.2 Material e Métodos.

4.2.1 Material vegetal.

4.2.2 Avaliação da resistência de famílias $\mathrm{F}_{2: 3}$ a $C$. graminicola.......................... 36

4.2.3 Genotipagem com marcadores moleculares.................................... 36

4.2.3.1 Extração de DNA ....................................................................... 36

4.2.3.2 Genotipagem com marcadores microssatélites.................................. 38

4.2.3.3 Genotipagem com marcadores AFLPS........................................ 38

4.2.4 Análises estatísticas.

4.2.5 Análise de ligação entre marcadores e construção

de mapa genético...

4.2.6 Mapeamento de QRLs pela análise de regressão linear múltipla

4.3 Resultados e Discussão.

4.3.1 Avaliação de progênies $\mathrm{F}_{2: 3}$ para resistência a $C$. graminicola.

4.3.2 Análise de marcadores microssatélites.

4.3.3 Análise de marcadores AFLPs.

4.3.4 Construção do mapa genético

4.3.5 Associação de marcadores moleculares a QRLs pela análise de regressão linear múltipla.

4.4 Conclusões.

5 ESTIMATIVAS DE DANOS EM MILHO TROPICAL OCASIONADOS PELA ANTRACNOSE DE COLMO.

Resumo.

Summary 71

5.1 Introdução. 72

5.2 Material e Métodos.

5.3 Resultados e Discussão.

5.4 Conclusões.

6 CONCLUSÕES GERAIS.

ANEXOS 


\title{
PATOSSISTEMA MILHO X Colletotrichum graminicola: ESTUDO DE HERANÇA, MAPEAMENTO DE GENES DE RESISTÊNCIA E ESTIMATIVAS DE DANOS NA PRODUÇÃO
}

\author{
Autor: RODRIGO RODRIGUES MATIELLO \\ Orientador: Prof. Dr. LUIS EDUARDO ARANHA CAMARGO
}

\section{RESUMO}

A incidência de Colletotrichum graminicola (Ces.) Wils como agente causal da antracnose do colmo aumentou significativamente nos últimos anos no Brasil devido ao incremento da área cultivada de milho aliado a mudanças nas práticas culturais. Os objetivos do presente trabalho foram determinar a herança da resistência à antracnose do colmo, identificar locos de resistência quantitativa ( $Q R L)$ por meio de marcadores moleculares e estimar os danos potenciais na produção de grãos. A análise de média de gerações foi usada para determinar o modo de herança da resistência em duas famílias derivadas do cruzamento entre duas linhagens resistentes (Das21 e Das64) com uma suscetível (Das86). As inoculações foram realizadas no estádio de florescimento pleno com uma suspensão de $1,8 \times 10^{5}$ conídios $/ \mathrm{mL}$. O 
comprimento de lesão foi medido após abertura dos colmos. Os resultados indicaram modos de herança distintos entre as famílias. Em Das86 x Das21, houve predomínio de efeitos genéticos de dominância e interações epistáticas. Por outro lado, em Das86 x Das64, houve predomínio de efeitos aditivos. As estimativas de heterose diferiram entre as famílias, o que pode ser atribuídos à constituição genética dos genitores. O mapeamento de QRLs foi realizado com base na análise de 118 progênies $F_{2: 3}$, provenientes do cruzamento Das86 x Das21, avaliadas em três ensaios. As avaliações consistiram da medida do comprimento de lesão trinta dias após a inoculação. As análises de ligação entre marcadores e QRLs foram efetuadas por meio da regressão linear múltipla. A proporção da variação fenotípica em resistência devida a associação de QRLs com marcadores para os três ensaios e análise conjunta, variou de $44 \%$ a $63 \%$. Nove marcadores foram identificados associados a QRLs no primeiro ensaio, 9 no segundo, 7 no terceiro e 13 analisando-se conjuntamente os experimentos. De maneira geral, foram identificados sete marcadores ligados a alelos de resistência nestes QRLs a C. graminicola, com coeficientes de regressão variando de $2,1 \%$ até $14,7 \%$. Para estimar os danos na produção dois ensaios foram instalados em esquema fatorial $2 \times 5$. Os tratamentos consistiram da combinação de híbridos, suscetível e resistente, e três épocas de inoculação (20, 40, 60 DAE) além de duas testemunhas. Diferenças significativas na produção e peso de espiga ocorreram apenas para o híbrido suscetível quando inoculado aos 20 DAE. Neste caso, as reduções em produção foram de 16,1 e 20,2\% para cada ensaio. Não foram verificadas diferenças significativas em comprimento de lesão em ambos os híbridos em função da data de inoculação. Conclui-se, portanto, que as perdas advindas da infecção no início do plantio não são devidas a maior severidade de ataque do patógeno. Este é o primeiro relato de mapeamento de vários QRLs a C. graminicola e de estimativas de danos deste patógeno em milho tropical. 


\title{
MAIZE X Colletotrichum graminicola PATHOSYSTEM: STUDY ON INHERITANCE, RESISTANCE GENE MAPPING AND YIELD REDUCTION ESTIMATES
}

\author{
Author: RODRIGO RODRIGUES MATIELLO \\ Adviser: Prof. Dr. LUIS EDUARDO ARANHA CAMARGO
}

SUMMARY

The incidence of Colletotrichum graminicola (Ces.) Wils as the causal agent of stalk rot has increased significantly in recent years in Brazil due to an increase in the area cultivated with maize, in addition to implemented changes in cultural practices. The objectives of this work were to determine the mode of inheritance of resistance to stalk anthracnose, identify quantitative resistance loci (QRL) by means of molecular markers, and estimate potential grain yield reduction. Generation means analysis was used for two families derived from a cross between two resistant (Das21 and Das64) and one susceptible (Das86) line. Inoculations were performed at the flowering stage with a suspension containing $1.8 \times 10^{5}$ conidia $/ \mathrm{mL}$. Lesion length was measured after opening the stalks. The results indicated distinct inheritance modes between families. In Das86 $\times$ Das21, dominance genetic effects and epistatic interactions were predominant. On the other hand, in Das86 $\times$ Das64 there was a predominance 
of additive effects. Heterosis estimates differed between families, which could be attributed to the genetic background of the inbred parents. QRL mapping was performed based on the analysis of $118 \mathrm{~F}_{2: 3}$ progenies from the Das86 $\times$ Das21 cross, evaluated in three trials. Evaluations consisted in measuring lesion lengths thirty days after inoculation. The linkage analysis between markers and QRLs were made by means of multiple linear regressions. The proportion of the phenotypic variation in resistance due to an association of QRLs with markers for the three trials and in the joint analysis ranged from $44 \%$ to $63 \%$. Nine markers associated with QRLs were identified in the first trial, 9 in the second, 7 in the third, and 13 when the experiments were analyzed jointly. In general, seven markers linked to resistance alleles were identified in these QRLs, with coefficients of regression ranging from $2.1 \%$ to $14.7 \%$. Two trials were installed to estimate yield reduction, in a $2 \times 5$ factorial design. Treatments consisted of a combination of hybrids, susceptible and resistant, and three inoculation times $(20,40,60 \mathrm{DAE})$, in addition to two controls. Significant differences in yield and ear weight occurred only for the susceptible hybrid when inoculated at 20 DAE. In this case, yield reductions were 16.1 and $20.2 \%$ for each trial compared to the non-inoculated control. No significant differences were observed for lesion length in any of the two hybrids as a function of inoculation date. It can therefore be concluded that losses caused by infection at the beginning of planting are not due to a greater severity of attack by the pathogen. This is the first report on the mapping of several QRLs to C. graminicola and on yield estimates for this pathogen in tropical maize. 


\section{INTRODUÇÃO}

A cultura do milho (Zea mays L.) apresenta grande importância sócioeconômica, não somente pela grande área que ocupa, mas também por todo complexo industrial que gira em torno de seu cultivo. $\mathrm{O}$ aumento da área cultivada verificado nos últimos anos deve-se ao desenvolvimento de híbridos mais produtivos, com maior adaptação aos ambientes, bem como a recentes mudanças nas práticas culturais, como o aumento do plantio de segunda época (safrinha) e o avanço da cultura para novas regiões do Centro-Oeste (Fernandes \& Oliveira, 1997).

Os resultados alcançados no país com a cultura de milho na safra 02/03 destacam-se no agronegócio brasileiro. A Companhia Nacional de Abastecimento (Conab) estima que a produção de grãos deste cereal deverá alcançar 45,8 milhões de toneladas, ou seja, um volume $30 \%$ superior à safra passada. Estima-se também um aumento de 13,9\% (400 mil hectares) na área com o plantio safrinha. Nesta safra, a produção obtida com o plantio tardio garantiu o abastecimento interno da cultura, atingindo aproximadamente $24 \%$ da produção nacional (Santos et al., 2003).

$\mathrm{O}$ incremento do plantio tardio aliado à adoção do plantio direto acarretou um aumento na incidência de doenças até então de importância secundária para a cultura. Dentre as doenças de importância atual, a antracnose do colmo, causada por Colletotrichum graminicola (Ces.) Wils, apresenta-se como fator limitante à obtenção de altas produtividades a ponto de ser considerada uma das mais importantes doenças da atualidade. O patógeno 
é responsável pela quebra do colmo e conseqüente acamamento da planta e pela interrupção do fluxo de nutrientes do colmo para as espigas. O uso de cultivares resistentes e a rotação de culturas são as estratégias de controle mais seguras, viáveis e de menor impacto ambiental deste patógeno.

Há vários estudos sobre o controle genético da resistência de milho à podridão do colmo (Lim \& White, 1978; Badu-Apraku et al., 1987a; Badu-Apraku et al., 1987b; Pereira et al., 1989; Weldekidan \& Hawk, 1993; Jung et al., 1994; Morello, 2000). Entretanto, dos genes de resistência relatados, apenas um foi geneticamente localizado no cromossomo 4 (Jung et al., 1994). Neste sentido, o mapeamento destes genes se faz necessário, tanto para melhor entender as bases genéticas da resistência de milho a este patógeno, como para desenvolver marcadores moleculares que possam ser usados em programas de melhoramento.

O objetivo geral deste trabalho foi estudar a herança da resistência a Colletotrichum graminicola, agente causador da podridão do colmo em milho bem como seu impacto potencial na produção. Seus objetivos específicos foram: 1) estudar a herança e ação gênica envolvida na resistência de milho à podridão do colmo por meio da análise de médias de gerações, 2) mapear regiões cromossômicas com marcadores moleculares e determinar seus efeitos na resistência à podridão do colmo e 3) estimar os danos na produção de grãos ocasionados pela infecção de C. graminicola. 


\section{REVISÃO DE LITERATURA}

\subsection{Podridões de colmo em milho}

Vários fungos causam podridão do colmo, doença de importância mundial por seus efeitos negativos no rendimento de grãos, morte prematura de plantas e quebra de colmo (Jarvis et al., 1984). Nos Estados Unidos, os agentes causais das podridões compreendem as espécies Gibberella zeae (Schwein) Petch, Colletotrichum graminicola (Ces.) Wils, Stenocarpella maydis (Berk.) Sutton e espécies do gênero Fusarium ( $F$. verticillioides, $F$. proliferatum e $F$. subglutinans) (Gatch \& Munkvold, 2002). No Brasil, a ocorrência da podridão do colmo está relacionada a C. graminicola, Diplodia maydis, D. macrospora, Fusarium graminearum e F. moniliforme (Pereira \& Pereira, 1976; Balmer \& Pereira, 1987; Reis \& Casa, 1996; Denti \& Reis, 2003).

Embora mais de um patógeno possa ocorrer simultaneamente nos colmos com podridão, um grupo de patógenos sempre predomina. De maneira geral, a diversidade de espécies pode ser alterada dentro de uma estação de cultivo em decorrência de mudanças em práticas culturais, ou ainda pela introdução de biótipos mais virulentos na população do patógeno (Wheeler et al., 1974; Kommedahl et al., 1979; Bergstrom \& Nicholson, 1999). Essas alterações na composição das espécies podem ter implicações diretas no tipo e na severidade da podridão do colmo, uma vez que os agentes causais podem variar em patogenicidade. Atualmente, acredita-se que C. graminicola e G. zeae 
sejam as mais destrutivas dentre as espécies causadoras de podridão (Gilbertson et al., 1985).

As podridões de colmo são especialmente favorecidas pela monocultura de milho uma vez que estes patógenos sobrevivem em restos culturais (Byrnes \& Carrol, 1986; Del Rio \& Zúngia, 1991). De fato, observa-se maior incidência desta doença em monoculturas comparado a sistemas de rotação de culturas (Denti \& Reis, 2001).

\subsection{Patossistema milho x C. graminicola}

Anteriormente à década de 70 , a podridão do colmo causada por $C$. graminicola, também denominada de antracnose de colmo, não era considerada de importância na América do Norte (Leonard \& Thompson, 1969; Nicholson \& Warren, 1976). Entretanto, epidemias verificadas no início dos anos 70 em campos de milho doce foram tão intensas que, em 2 anos, essas áreas foram completamente abandonadas (Warren et al., 1973). Estimativas dos efeitos da antracnose foliar e do colmo na redução do rendimento de grãos variaram de 0 a 40\%, sendo altamente dependentes do híbrido utilizado, do ambiente e da época de infecção (Smith, 1976; Perkins \& Hooker, 1979; Keller \& Bergstrom, 1988; Callaway et al., 1992). Nos Estados Unidos, os danos na produção de grãos em decorrência da antracnose de colmo chegaram a 28\% na safra de 1980 (Carson \& Hooker, 1981). No Brasil, o primeiro relato da doença foi feito por Silveira et al. (1965) em campos de produção de milho híbrido na região de Campinas. De maneira geral, os danos estimados na produção de grãos variaram de 12 a 40\% (Silveira et al., 1965; Nazareno, 1989).

Com relação a biologia do patógeno (Colletotrichum graminicola), este forma acérvulos esféricos ou piriformes (8-15 $\mu \mathrm{m})$ com setas sobre o tecido afetado. Seus conídios são falciformes, medindo 23,5 - 29,0 $\mu \mathrm{m} \times$ 3,5 - 5,0 $\mu \mathrm{m}$, respectivamente, para comprimento e largura, quando cultivado em meio de 
cultura (Sutton, 1980; Pontes, 1987). O patógeno sobrevive como saprófita em resíduos culturais na superfície do solo por até dez meses (Naylor \& Leonard, 1977). No entanto, se estes forem enterrados, reduz-se a possibilidade de sua sobrevivência. Em sementes, o patógeno sobrevive até 3 anos (Warren, 1977). Assim, em climas frios, recomenda-se rotações de pelo menos dois anos agrícolas e uso de sementes sadias como formas de controle cultural (Lipps, 1988).

Os conídios podem permanecer viáveis de semanas a meses, dependendo da umidade relativa do ar e contanto que os mesmos estejam recobertos por uma matriz mucilaginosa produzidos pelo próprio fungo (Nicholson \& Moraes, 1980). Sua dispersão ocorre por respingos de chuva ou pelo vento (Bergstrom \& Nicholson, 1999). A presença de água é necessária para a germinação dos conídios, pois solubiliza inibidores de germinação presentes na matriz mucilaginosa. Esta matriz não está somente envolvida na sobrevivência dos conídios, mas também na indução da patogênese (Bergstrom \& Nicholson, 1983). Existem evidências de que essa matriz possui, além de inibidores de germinação, enzimas importantes no estabelecimento das relações patógeno-hospedeiro (Pascholati et al., 1993; Anderson \& Nicholson, 1996).

A antracnose do colmo é mais severa em lavouras que apresentam injúrias ocasionadas por insetos, principalmente a larva de Ostrinia nubilalis, comum em campos de produção da América do Norte. No Brasil, a broca da cana-de-açúcar (Diatraea saccharalis) desempenha o mesmo papel (Fancelli \& Dourado Neto, 2000). De maneira geral, a infecção natural do colmo inicia-se com a deposição de conídios na base da planta provenientes de propágulos infectivos oriundos de lesões esporulantes da folha ou de restos culturais. Os sintomas surgem geralmente na epiderme do colmo, logo após a polinização, na forma de lesões estreitas, longitudinais, com aspecto encharcado, inicialmente de coloração pardo-avermelhadas, que se tornam castanho escuro e pretas (Messiaen et al., 1959; Dale, 1963; Silveira et al., 1965; Shurtleff, 
1980). A podridão de antracnose tem sido mais severa em regiões quentes e úmidas, com extensos períodos nublados. O patógeno infecta o colmo em vários estádios de desenvolvimento da planta, podendo levá-la à morte antes do florescimento. Sob condições favoráveis, a colonização do sistema vascular resulta em murcha. A colonização sistêmica dos colmos no início do estádio reprodutivo pode resultar em significativas reduções no rendimento de grãos (Keller et al., 1986; Fancelli \& Dourado Neto, 2000).

\subsection{Genética da resistência a C. graminicola}

As condições ambientais influenciam a resistência do hospedeiro. A alta intensidade de luz, por exemplo, está relacionada a um aumento da resistência (Hammerschmidt \& Nicholson, 1977). Este fato ocorre independentemente do nível de resistência / suscetibilidade do genótipo. Por outro lado, a redução da intensidade de luz resulta em aumento da suscetibilidade (Schall et al., 1980). Acredita-se que tal fenômeno se deve ao fato da resistência estar associada a biossíntese de compostos fenólicos, os quais são altamente dependentes da luz (Dixon \& Paiva, 1995; Holton \& Cornish, 1995; Nicholson \& Hammerschmidt, 1992). A resistência também pode estar associada ao estádio fenológico da cultura, pois colmos na fase vegetativa são mais suscetíveis à colonização, provavelmente em decorrência da alta concentração de açúcares (Bergstrom \& Nicholson, 1999). Além disso, a resistência pode ser atribuída à rapidez na cicatrização nos pontos de penetração do patógeno (Muimba-Kankolongo \& Bergstrom, 1990; MuimbaKankolongo \& Bergstrom, 1992).

Com relação ao controle genético da resistência, Carson \& Hooker (1981) relataram efeitos genéticos aditivos que responderam por mais de $90 \%$ da variação total. Estimativas de alta herdabilidade, ação gênica aditiva e famílias $F_{3}$ com elevado nível de resistência indicaram que os métodos pedigree e seleção recorrente devem ser efetivos em programas de 
melhoramento. Toman \& White (1993), através da análise de média de gerações, relataram efeitos genéticos tanto aditivos como dominantes e estimaram um número reduzido de genes de resistência. Weldekidan \& Hawk (1993) observaram soma de quadrados para capacidade geral de combinação quatro a cinco vezes maior que para capacidade específica, indicando que efeitos aditivos foram mais importantes que os dominantes. Callaway et al. (1990) encontraram heterose e capacidade de combinação específica e geral significativas, indicando que tanto efeitos aditivos como não aditivos foram importantes.

Resistência do tipo monogênica dominante em relação à antracnose de colmo foi comprovada pela primeira vez por Badu-Apraku et al. (1987a). A avaliação foi baseada numa escala diagramática de entrenós descoloridos. Posteriormente, este tipo de herança também foi descrita por Morello (2000). C. graminicola apresenta a capacidade de infectar e colonizar tanto folhas como colmos. Entretanto, a literatura indica que genes distintos controlam as reações do hospedeiro a estes dois tipos de infecção (White et al., 1979; Zuber et al., 1981; Pereira, 1983; Badu-Apraku et al., 1987b; Morello, 2000).

Com relação a localização de genes de resistência a C. graminicola, Carson \& Hooker (1982), utilizando translocações recíprocas, concluíram que os braços longos dos cromossomos 1, 4 e 8, e os dois braços do cromossomo 6 abrigam genes de resistência. Com o advento das técnicas de marcadores moleculares, vários genes condicionando resistência a diversos patógenos já foram mapeados (MacMullen \& Simcox, 1995). Entretanto, neste patossistema, até o momento, apenas uma região cromossômica contendo genes de resistência foi mapeada no cromossomo 4 com o auxílio de marcadores RFLP (Jung et al., 1994).

\subsection{Marcadores moleculares e mapeamento genético}

\subsubsection{Marcadores microssatélites (SSR)}


Marcadores moleculares microssatélites, também denominados de marcadores SSR ("Simple Sequence Repeats"), foram descritos inicialmente em humanos por Litt \& Luty (1989). Em plantas, microssatélites estão amplamente distribuídos nos cromossomos, com freqüência média de um a cada 50 mil pares de base. Consistem em seqüências curtas de nucleotídeos, geralmente de 2-10 pb, repetidas em tandem e flanqueadas por seqüências únicas não repetidas, sendo o elemento repetido mais comum o di-nucleotídeo AT (Morgante \& Olivieri, 1993). Ocorrem de maneira relativamente dispersa nos cromossomos de milho, são co-dominantes e apresentam um satisfatório grau de polimorfismo (Chin et al., 1996). A grande vantagem deste marcador é que podem ser visualizados em géis de agarose e poliacrilamida após sua amplificação via PCR usando iniciadores ("primers") de seqüências específicas (Ferreira \& Grattapaglia, 1995). Além disso, apresentam localização definida nos 10 grupos de ligação do mapa genético consenso que, por sua vez, apresentam correspondência conhecida com os cromossomos. Atualmente, mais de 2000 primers estão disponíveis (www.agron.missouri.edu).

\subsubsection{Marcadores AFLPs}

Marcadores AFLP ("Amplified Fragment Length Polymorphism" ou polimorfismo de comprimento de fragmentos amplificados) representam técnica relativamente recente que permite obter um grande número de fragmentos amplificados (locos marcadores) a partir de uma única reação de PCR (Vos et al., 1995). Esta tecnologia combina a especificidade, a resolução e o poder de amostragem da digestão com enzimas de restrição com a rapidez e praticidade de detecção de polimorfismos via PCR (Ferreira \& Grattapaglia, 1995). O método AFLP gera um elevado número de marcadores por gel, permitindo uma rápida saturação de mapas genéticos (Castiglioni et al., 1999). Constitui assim poderosa ferramenta para o mapeamento de genes que controlam características de importância agronômica em plantas como a resistência a 
doenças (Van der Voort et al., 1999; Xu et al., 1999). Além disso, o método tem sido utilizado para estudos de taxonomia e diversidade genética em bactérias, fungos, animais e plantas (Müeller \& Wolfenbarger, 1999).

A tecnologia compreende quatro etapas que incluem 1) a digestão do DNA genômico com duas enzimas de restrição; 2) a ligação de adaptadores específicos nas extremidades coesivas criadas pelas enzimas de restrição; 3) a pré-amplificação de fragmentos e 4) uma amplificação seletiva dos fragmentos pré-amplificados. Na seqüência, os fragmentos amplificados são separados em gel de poliacrilamida de alta resolução. Os resultados relatados na literatura permitem afirmar que os AFLPs são os mais eficientes entre os marcadores moleculares devido a capacidade de revelar um grande número de fragmentos numa única reação de PCR, demonstrando um índice de eficiência 10 vezes superior aos demais métodos moleculares (Pejic et al., 1998). Vários mapas de ligação em milho baseados em marcadores AFLPs já foram relatados (Pejic et al.,1998; Ajmone-Marsan et al.,1998; Melchinger et al.,1998; Vuylsteke et al., 1999; Castiglioni et al., 1999). O nível de polimorfismo detectado depende do tipo de população utilizada e das combinações de enzimas de restrição. Vuylsteke et al. (1999) relataram que o polimorfismo gerado em uma população $F_{2}$ foi superior ao de uma população de linhagens recombinantes, com magnitude variando de 35,7 a 48\%, dependendo da combinação das enzimas de restrição. Castiglioni et al. (1999) relataram nível de polimorfismo variando em média de 14,9\% para combinações de enzimas EcoRI e Msel a 19,6\% para Pstl e Msel numa população $\mathrm{F}_{2}$. Essas diferenças no nível de polimorfismo são atribuídas a localização preferencial dos fragmentos gerados pela combinação Eco/Mse nas regiões centroméricas dos cromossomos, ao passo que os fragmentos oriundos da combinação Pst/Mse apresentam distribuição mais aleatória entre e dentro dos cromossomos. Castiglioni et al. (1999) obtiveram um mapa de ligação com uma cobertura de 2057 cM, com marcadores distribuídos a cada 6,6 cM. Em outro trabalho, Vuylsteke et al. (1999) construíram dois mapas saturados com cobertura genômica de 1178,1 cM 
(linhas puras recombinantes) e de $1375,6 \mathrm{cM}\left(\mathrm{F}_{2}\right)$. A diferença observada na cobertura do genoma (comprimento do mapa) pode ser explicada pelo fato de Castiglioni et al. (1999) não levar em consideração a interferência na estimativa das freqüências de recombinação entre as marcas.

\subsubsection{Mapeamento genético usando marcadores moleculares}

O mapeamento genético via marcadores moleculares requer uma seleção prévia de locos polimórficos entre os genitores de uma população segregante e posterior análise de segregação dos mesmos na população. A determinação da ligação entre marcadores moleculares a regiões genômicas responsáveis pela variação fenotípica em resistência, possibilita uma análise individualizada destas regiões, então denominadas QTLs ("quantitative trait loci") de resistência. A estratégia de associar marcadores microssatélites como "âncoras" nos grupos de ligação permite a localização cromossômica de marcadores AFLPs (Vuylsteke et al., 1999; Ajmone-Marsan et al., 2001).

A precisão dos resultados obtidos com o mapeamento genético depende da seleção de genitores discrepantes para o caráter em estudo, da obtenção de uma população segregante e da avaliação precisa do fenótipo na população. Populações segregantes obtidas de cruzamentos controlados entre linhagens endogâmicas maximizam o desequilíbrio de ligação entre locos, permitindo estabelecer ligações genéticas com mais precisão. O máximo de informação genética é obtido quando se utiliza uma população da geração $F_{2}$ devido ao forte desequilíbrio de ligação nesta geração, e marcadores codominantes que permitem discernir locos homozigóticos dos heterozigóticos (Mather,1938). A grande vantagem da utilização de indivíduos $F_{2}$ para a construção de mapa de ligação é que este combina duas vezes mais informação de eventos de recombinação do que indivíduos oriundos de retrocruzamento. Neste sentido, numa única reação de PCR dois alelos informativos poderão ser amostrados, sendo um alelo de cada genitor. 
Atualmente, vários marcadores genéticos estão disponíveis. Dentre eles os baseados em polimorfismos do DNA (RFLPs, RAPDs, SSRs e AFLPs) são os mais utilizados pois possibilitam a construção de mapas de ligação mais precisos (Coelho \& Silva, $2002^{1}$ ).

Um dos delineamentos genéticos mais comumente utilizados no mapeamento genético em milho é a utilização de indivíduos $F_{2}$ oriundos do cruzamento entre duas linhagens homozigóticas contrastantes para o caráter em estudo. Este delineamento tem como inconveniente o fato de que os indivíduos que são utilizados para o mapeamento são únicos. Neste aspecto, recomenda-se que em situações onde a avaliação de um determinado caráter exige vários ambientes, como é o caso de resistência a doença, sejam avaliadas famílias $F_{2,3}$, possibilitando assim uma avaliação fenotípica mais precisa, com repetições e em vários locais.

A construção de um mapa genético envolve a avaliação do padrão de segregação das marcas em indivíduos segregantes, a análise de desequilíbrio de ligação, a determinação da distância entre marcas e o conseqüente ordenamento linear das mesmas em grupos de ligação. Mapas genéticos de alta densidade são extremamente úteis na pesquisa genética básica e aplicada. De maneira geral, eles servem para: 1) localizar genes de interesse, 2) facilitar o melhoramento assistido por marcadores e a clonagem baseada em mapa e 3) possibilitar o entendimento da base biológica de características muito complexas (Vuylsteke et al., 1999).

O princípio básico que fundamenta o mapeamento de QTLs é a existência de desequilíbrio de ligação decorrente da baixa freqüência de recombinação entre locos proximamente ligados. Várias metodologias podem ser utilizadas para o mapeamento de QTLs, como a análise de agrupamentos segregantes (Bulked Segregant Analysis; Michelmore et al., 1991), análise de marcas simples (Single Point Analysis; Edwards et al., 1987), mapeamento por

\footnotetext{
${ }^{1}$ COELHO, A.S.G.; SILVA, H.D. Construção de mapas genéticos e mapeamento de QTL's. Piracicaba, 2002. 65p. (apostila).
} 
intervalo (Interval Mapping; Lander \& Botstein, 1989), mapeamento por intervalo composto (Composite Interval Mapping; Zeng, 1993; Zeng, 1994; Jansen, 1993; Jansen, 1994; Jansen \& Stam, 1994) e, recentemente, o mapeamento por intervalo múltiplo (Multiple Interval Mapping; Kearsey \& Hyne, 1994; Hyne \& Kearsey, 1995; Wu \& Li, 1994; Wu \& Li, 1996).

O método BSA ("Bulked Segregant Analysis") consiste na avaliação de dois grupos de indivíduos obtidos de pontos extremos da curva de distribuição do caráter em estudo. Espera-se que os alelos dos marcadores que estiverem associados aos alelos do QTL estejam distribuídos de forma desigual entre os dois grupos, possibilitando sua detecção (Michelmore et al., 1991). Segundo Lynch \& Walsh (1998), o método BSA não é o mais recomendado para detecção de QTLs de pequeno efeito, pois na composição dos "bulks" apenas as regiões com forte influência no caráter estarão sendo amostradas em detrimento daquelas de pequeno efeito. Neste caso, a análise requer a utilização de populações segregantes com maior número de indivíduos, muitas vezes indisponíveis.

A análise de marcas simples ("Single Point Analysis") é considerada, a exemplo do método BSA, o procedimento mais simples na detecção de QTLs, pois não necessariamente exige a construção de um mapa de ligação (Tanksley, 1993). A metodologia consiste na comparação estatística do valor médio do caráter sob estudo entre as classes genotípicas de um marcador. A significância do teste estatístico indica a existência ou não de ligação do marcador molecular com um QTL. As desvantagens inerentes são a dificuldade de detecção e sub-estimativas da magnitude dos QTLs quando a distância entre marcador e QTL for grande (>35 cM) (Liu, 1998).

O mapeamento por intervalo baseia-se na análise de freqüências de conjuntos de marcadores ligados e o QTL de interesse (Lander \& Botstein, 1989). A utilização de marcadores ligados na análise aumenta o poder de detecção dos QTLs, permite estimar seus efeitos sobre a expressão do caráter e determina sua distância em relação aos marcadores. O maior benefício do 
mapeamento por intervalo em relação a marcas simples ocorre quando a distância entre marcadores situa-se entre 20 e 35 cM. Para distâncias menores (20 cM), não existe diferença entre as metodologias, ao passo que para aquelas maiores que $35 \mathrm{cM}$, nem mesmo este método mostra-se eficiente (Lander, 1993, citado por Coelho, 2000). Outro problema é quando existem outros QTLs no mesmo cromossomo, uma vez que isto pode interferir na determinação das posições dos mesmos (Halley \& Knott, 1992; Martinez \& Curnow, 1992). Em relação a métodos tradicionais de mapeamento, este requer análise de menor número de indivíduos (Zeng, 1994).

A metodologia de mapeamento por intervalo composto foi desenvolvida com o intuito de eliminar a interferência de QTLs adjacentes ao intervalo e com isto aumentar a eficiência na detecção de QTLs. O método agrega, num único modelo, a análise de regressão linear múltipla e o mapeamento por intervalo (Jansen, 1993; Zeng, 1993; Zeng, 1994). Individualmente, a análise de regressão múltipla não é a melhor metodologia, pois o coeficiente de regressão parcial é uma estimativa enviesada do efeito do respectivo QTL (Zeng, 1993). A base do método consiste em testar um determinado intervalo para um QTL sem que ocorra a interferência de outro QTL localizado em regiões adjacentes ao teste (Zeng, 1994).

A análise biométrica de caracteres quantitativos tem revelado a importância das interações epistáticas entre locos e das interações dos QTLs com os ambientes nos quais são avaliados. As abordagens estatísticas utilizadas para o mapeamento de QTLs consideram um modelo genético simplificado, ou seja, ausência de epistasia e interações QTLs $x$ ambiente. Entretanto, Wang et al. (1999) afirmam que a simplificação dos modelos estatísticos pode levar a obtenção de estimativas enviesadas da posição, a subestimativa do efeito do QTL e a redução do poder de detecção dos mesmos no mapa de ligação. Neste sentido, mais estudos deverão ser conduzidos nesta área com o aprimoramento e compartilhamento do conhecimento entre geneticistas biométricos e moleculares para o desenvolvimento de novas 
ferramentas estatístico-moleculares a serem utilizadas pelos programas de melhoramento vegetal. 


\section{HERANÇA DA RESISTÊNCIA À ANTRACNOSE DO COLMO (Colletotrichum graminicola Ces. Wils) EM LINHAGENS ENDOGÂMICAS DE MILHO TROPICAL}

\section{Resumo}

A análise de média de gerações foi usada para estudar o modo de herança da resistência à antracnose de colmo em duas famílias derivadas do cruzamento de três linhagens endogâmicas de milho tropical. Cada família foi constituída de seis gerações $\left(P_{1}, P_{2}, F_{1}, F_{2}, B C P_{1}\right.$ e $\left.B C P_{2}\right)$ as quais foram avaliadas para a resistência em dois ensaios, num delineamento de blocos casualizados em esquema de parcelas subdivididas. As médias das gerações foram analisadas de acordo com o modelo de Mather \& Jinks (1971). As inoculações foram realizadas no estádio de florescimento pleno com uma suspensão de 1,8 × $10^{5}$ conídios $/ \mathrm{mL}$, injetada no colmo com auxílio de uma seringa. O comprimento de lesão foi medido após abertura dos colmos, trinta dias após a inoculação. Os resultados indicaram modos de herança distintos entre as famílias. Em uma família houve predomínio de efeitos genéticos de dominância nas duas épocas de semeadura. Além disto, interações epistáticas aditivo $\mathrm{x}$ dominante e aditivo $\mathrm{x}$ aditivo também foram encontradas. Valores intermediários de herdabilidade no sentido amplo indicaram uma herança complexa, sendo esta provavelmente governada por vários genes de pequeno efeito. Por outro lado, na segunda família, o modelo genético aditivo-dominante foi suficiente para explicar as variações entre as médias das gerações. A ação 
gênica aditiva predominou nos dois ensaios. Neste cruzamento, a herança da resistência parece ser governada por poucos genes de grande efeito. Estimativas de heterose diferiram amplamente entre as famílias, as quais podem ser atribuídas à constituição genética das linhagens genitoras. A presença de variabilidade genética para resistência à antracnose do colmo nas gerações de segregação, de ambas as famílias, indica possibilidade de ganhos genéticos através da seleção.

\section{Inheritance of resistance to anthracnose stalk rot (Colletotrichum graminicola Ces. Wils) in tropical maize inbred lines}

\section{Summary}

Generation means analysis was used to study the mode of inheritance of resistance to anthracnose stalk rot in two families derived from crosses between three tropical maize inbred lines. Each family was comprised of six generations $\left(\mathrm{P}_{1}, \mathrm{P}_{2}, \mathrm{~F}_{1}, \mathrm{~F}_{2}, \mathrm{BCP}_{1}\right.$ and $\left.\mathrm{BCP}_{2}\right)$ that were evaluated for resistance in two trials under a randomized complete block design using subdivided plots. Generation means were analyzed according to the model of Mather \& Jinks (1971). Inoculations were performed at the flowering stage using a suspension of $1.8 \times 10^{5}$ conidia/mL applied into the stalk by a syringe. Lesion length was directly measured by opening the stalk thirty days after inoculation. Results indicated contrasting modes of inheritance between families. In one family dominant gene effects predominated. Besides, additive $x$ dominant and additive $x$ additive interactions also were found. Intermediate values of broadsense heritability indicated a complex inheritance probably conditioned by several genes of small effects. On the other hand, an additive-dominant genetic model sufficed to explain the variation between generation means in the second family, where additive gene effects predominated in both trials. Few genes of 
major effects most likely control disease resistance in this cross. Estimates of heterosis widely differed between families, which can be attributed to the genetic background of the parental lines. The presence of genetic variability for resistance to anthracnose stalk rot in the segregating generations of both families indicated the possibility of genetic gains through selection.

\subsection{Introdução}

Nos últimos anos, a expansão da cultura na região Centro-Oeste do Brasil e o aumento nas áreas de cultivo de milho de segunda época acarretaram um aumento progressivo na severidade de doenças, até então consideradas secundárias para a cultura (Silva, 1997; Fancelli \& Dourado Neto, 2000). Dentre elas, destaca-se à antracnose do colmo, causada por Colletotrichum graminicola (Ces.) Wils. Neste caso, outro fator importante para o incremento desta doença foi a adoção do sistema de semeadura direta, uma vez que $C$. graminicola pode sobreviver em restos culturais por até dez meses (Naylor \& Leonard,1977).

Os sintomas da antracnose no colmo surgem geralmente na epiderme, com lesões estreitas, longitudinais, de aspecto encharcado, inicialmente de coloração pardo-avermelhada, que se torna castanho escuro e preta (Messiaen et al., 1959; Dale, 1963; Silveira et al., 1965; Shurtleff, 1980). Estes sintomas iniciam-se geralmente logo após a polinização. O fungo também infecta folhas mas, no entanto, há indicações que genes distintos condicionam resistência para antracnose foliar e do colmo (Pereira, 1983; Morello, 2000).

Estudos relativos ao modo de herança da resistência genética indicam que esta é condicionada por poucos locos em sua maior parte de ação gênica aditiva (Lim e White, 1978; Carson \& Hooker, 1981; Weldekidan \& Hawk 1993). Além disto, estimativas do número de genes de resistência indicam controle oligogênico (Toman \& White, 1993). Entretanto, Callaway et al. (1990) 
encontraram heterose e capacidade geral e específica de combinação significativas, indicando que tanto efeitos aditivos como dominantes também podem contribuir para resistência. Enquanto a maioria dos estudos envolvendo este patossistema indica uma herança quantitativa da resistência, Badu-Apraku et al. (1987a) relataram um único gene dominante num cruzamento entre linhas tropicais e temperadas de milho.

Uma vez que o uso de cultivares resistentes é a estratégia mais eficiente no controle da doença, o conhecimento do modo de herança assegura ao melhorista definir o melhor método de seleção, incrementando sua eficiência e maximizando os ganhos genéticos durante a seleção. Assim, o presente trabalho teve por objetivo estudar o modo de herança da resistência à antracnose do colmo em gerações descendentes de dois cruzamentos entre linhagens tropicais de milho.

\subsection{Material e Métodos}

\subsubsection{Material vegetal}

Três linhagens endogâmicas (Das21, Das64 e Das86) foram utilizadas para desenvolver duas famílias a partir do cruzamento entre Das86 $\mathrm{x}$ Das21 e Das86 x Das64. A linhagem Das21 é resistente à antracnose de colmo. É originária de uma população sintética de linhas tropicais com predomínio do germoplasma Suwan DMR, desenvolvida na Tailândia através da seleção de genótipos tropicais do Caribe e Tuxpeño. Atualmente, essa população, denominada CMS5, é utilizada e distribuída pelo Centro Nacional de Pesquisa de Milho e Sorgo da Empresa Brasileira de Pesquisa Agropecuária (Silva, 2001). As linhagens Das64 e Das86 foram obtidas de uma população sintética constituída por linhagens oriundas da população Amarillo Dentado e populações flints do Caribe. Ambas as linhagens possuem ciclo precoce e 
grãos semiduros alaranjados. A diferença entre elas é que Das64 apresenta estatura reduzida e resistência à antracnose do colmo, enquanto Das86 apresenta estatura intermediária e alta suscetibilidade (Coêlho et al., 2001).

Os ensaios de campo foram compostos pelas gerações parentais $\left(P_{1}\right.$ e $\left.P_{2}\right), F_{1}, F_{2}$ e os dois retrocruzamentos $\left(B P_{1}\right.$ e $\left.B C P_{2}\right)$ de cada família.

\subsubsection{Inoculação}

O patógeno foi isolado de pedaços de colmos de milho coletados em Iraí de Minas (MG). Os fragmentos foram desinfestados superficialmente (30 segundos álcool 70\%, 2 minutos solução de hipoclorito 1\% e 1 minuto água destilada) e depositados em placas de Petri Pirex ${ }^{\circledR}$, contendo meio de cultura aveia-ágar ( $40 \mathrm{~g}$ de farinha de aveia, $17 \mathrm{~g}$ de ágar, $1000 \mathrm{~mL}$ de água). As placas foram mantidas em câmara de crescimento a $22 \pm 2^{\circ} \mathrm{C}$ sob lâmpadas fluorescentes, em regime de 12h luz / 12h escuro, até a esporulação da colônia (aproximadamente 14 dias).

O inóculo foi preparado através da adição de $20 \mathrm{~mL}$ de água destilada às placas de Petri contendo colônias esporulantes do fungo, seguida de uma raspagem superficial da cultura para liberação dos conídios. A suspensão foi filtrada através de uma camada dupla de gaze. Antes da inoculação, a concentração de conídios foi ajustada para 1,8 x 10 conídios/mL (Morello, 2000).

\subsubsection{Ensaios de campo}

Dois ensaios foram conduzidos em novembro e dezembro de 2001 em Indianópolis (MG), utilizando o delineamento de blocos casualizados. Os tratamentos foram dispostos em esquema de parcelas subdivididas com três repetições, onde o efeito de famílias foi estudado nas parcelas e o efeito das 
gerações nas subparcelas. As gerações parentais e o híbrido foram representados por uma linha de 5,0m contendo aproximadamente 20 plantas em cada repetição; a geração $F_{2}$ por quatro e as gerações de retrocruzamento $\left(\mathrm{BCP}_{1}\right.$ e $\left.\mathrm{BCP}_{2}\right)$ por duas linhas. O espaçamento entre linhas foi de $0,90 \mathrm{~m}$.

As plantas foram inoculadas no estádio de florescimento pleno pela injeção de $1 \mathrm{~mL}$ de uma suspensão de $1,8 \times 10^{5}$ conídios $/ \mathrm{mL}$ no primeiro internódio visível acima da superfície do solo usando uma seringa de uso veterinário de $50 \mathrm{~mL}$ (Figura 1 ). Os sintomas foram avaliados 30 dias após a inoculação pelo seccionamento longitudinal do colmo com auxílio de uma máquina serra-fita elétrica (Figura 2) e medição do comprimento da lesão com fita métrica (cm).

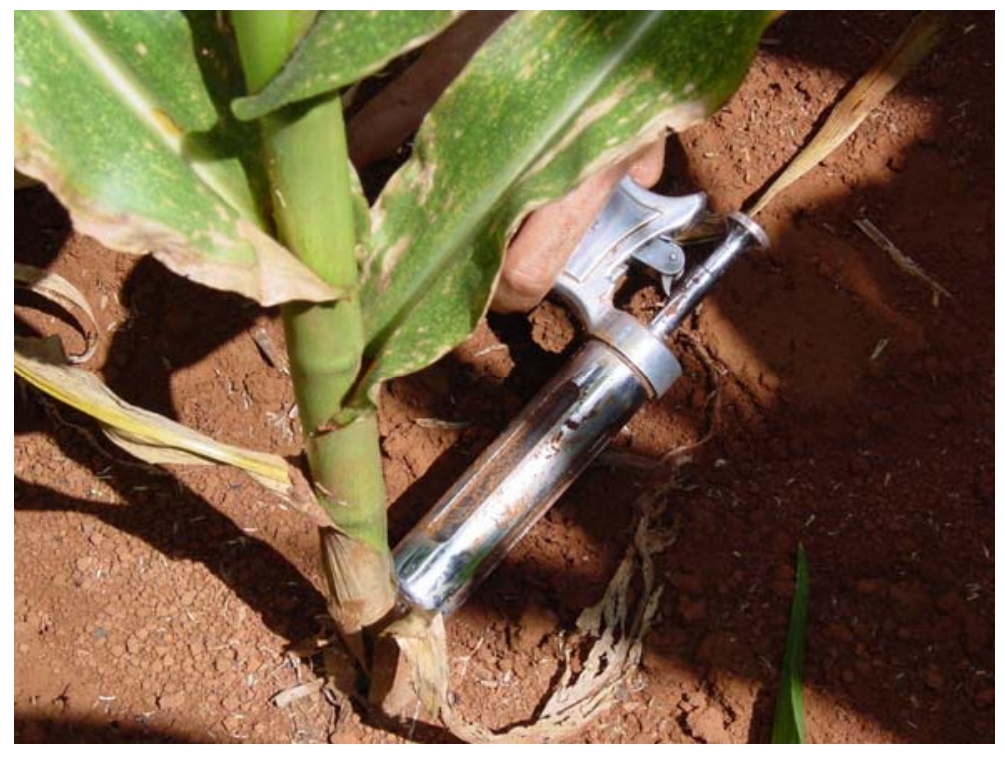

Figura 1 - Inoculação artificial de C. graminicola pela injeção de 1,0mL da suspensão de esporos na concentração $1,8 \times 10^{5}$ com o auxílio de seringa de uso veterinário 


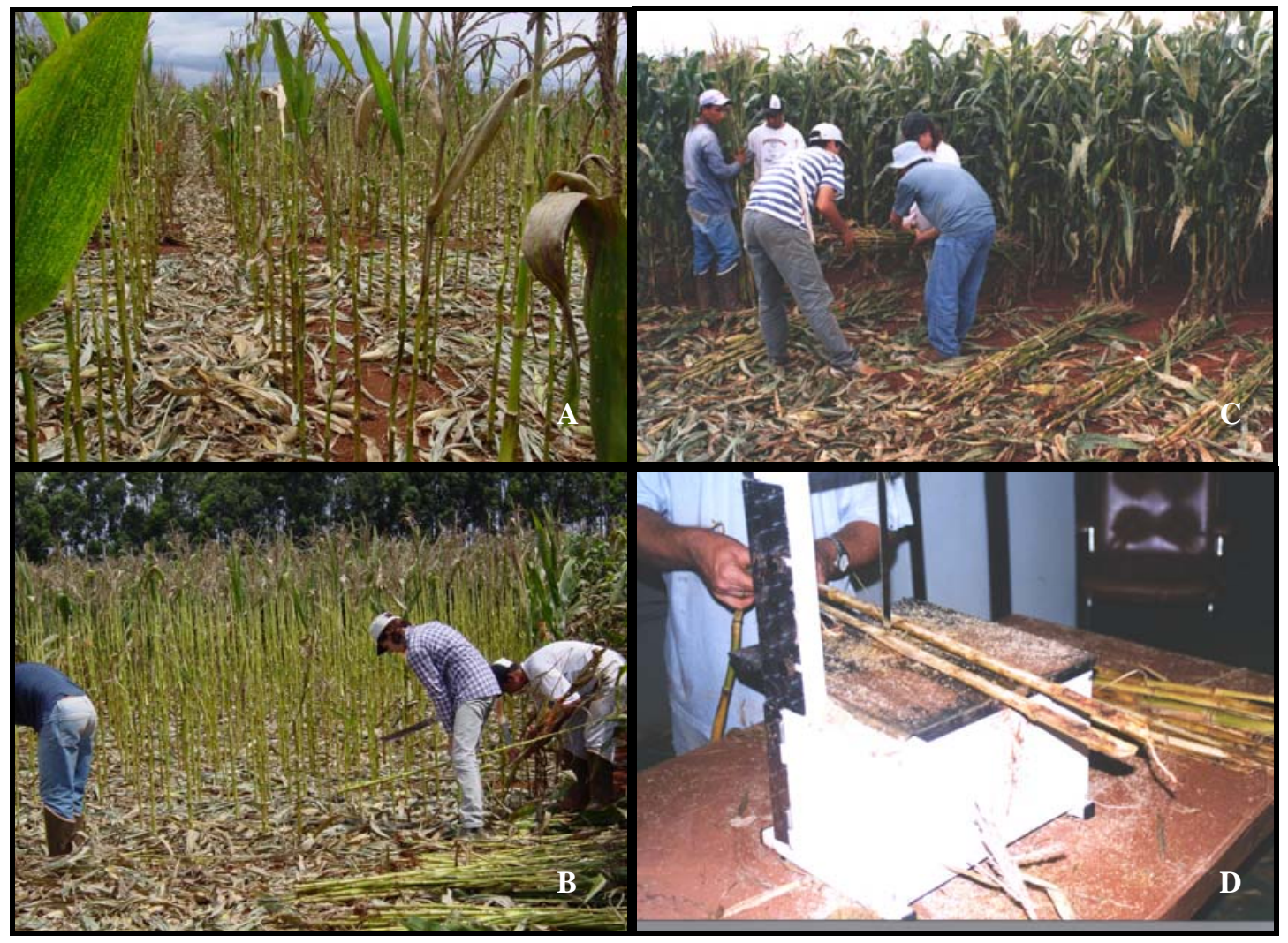

Figura 2 - Visão parcial dos ensaios de campo. A) retirada de folhas e pendão, B) corte dos colmos, C) amarrio dos colmos e D) corte longitudinal com serra-fita elétrica 


\subsubsection{Análises estatísticas}

Análises de variância (ANOVA) foram realizadas para cada ensaio utilizando o programa estatístico SAS (SAS Institute, 1993) com a finalidade de detectar diferenças significativas entre e dentro das famílias. Os efeitos genéticos foram estimados através da análise das médias das gerações segundo o modelo $Y_{k}=m+w_{1} a+w_{2} d+\theta_{k}$, no qual $Y$ é a média da geração $k$, $\mathbf{m}$ é a média geral, a representa o efeito aditivo, $\mathbf{d}$ o efeito genético dominante, $\mathbf{W}_{\mathbf{1}}$ e $\mathbf{w}_{\mathbf{2}}$ as relativas contribuições destes efeitos para cada média da geração e $\theta_{\mathrm{k}}$ os desvios do modelo para cada família (Mather \& Jinks, 1971). As estimativas dos parâmetros $\hat{\mu}$, $\hat{a}$ e $\hat{d}$ do modelo foram obtidas pela equação $\beta=\left(X^{\prime} X\right)^{-1}\left(X^{\prime} Y\right)$ pela resolução do sistema $(y=X \beta+\varepsilon)$, onde $Y$ é o vetor das médias observadas das gerações para cada família, $X$ a matriz dos coeficientes e $\beta$ o vetor dos parâmetros (Mather \& Jinks, 1971). Inicialmente, os parâmetros genéticos foram estimados usando o modelo genético reduzido composto de efeitos aditivos, dominantes e desvios do modelo. Na presença de desvios significativos, utilizou-se um modelo completo, onde foram incluídas as interações epistáticas aditivo $\mathrm{x}$ aditivo e aditivo $\mathrm{x}$ dominante. $\mathrm{A}$ análise de variância pelo método dos quadrados mínimos foi realizada segundo Miranda Filho (1991).

As estimativas de heterose foram calculadas pela fórmula: $\mathrm{H}=\left(\mathrm{F}_{1-}\right.$ $M P$ ), onde MP é a média do comprimento de lesão das linhagens genitoras e $F_{1}$ o comprimento de lesão da geração híbrida. As estimativas de herdabilidade no sentido amplo foram calculadas pela fórmula: $h a^{2}=\left(\sigma_{F 2}^{2}-\sigma_{e}^{2}\right) / \sigma_{F 2}^{2}$, onde $\sigma_{F 2}^{2}$ é a variância fenotípica dos indivíduos da geração $F_{2}$ e $\sigma_{e}^{2}$ a variância ambiental entre indivíduos das gerações geneticamente homogêneas $\left(P_{1}, P_{2}\right.$ e $F_{1}$ ), estimada através do agrupamento da soma de quadrados e dos graus de liberdade das linhagens genitoras e da geração $F_{1}$ (Hallauer \& Miranda Filho, 1988). 


\subsection{Resultados}

A análise conjunta dos dois ensaios indicou interação significativa entre ensaios x gerações(famílias) para o comprimento médio de lesão (dados não apresentados). Assim, optou-se por apresentar e discutir os resultados baseados nas análises de variância individuais de cada ensaio. Diferenças significativas entre e dentro de famílias foram verificadas para o comprimento médio de lesão em ambos os ensaios (Tabela 1). A linhagem parental Das86 foi a mais suscetível, ao passo que Das64 comportou-se como a mais resistente nos dois ensaios (Tabela 2).

Tabela 1. Resumo das análises de variância do comprimento médio de lesão de C. graminicola no primeiro e segundo ensaio

\begin{tabular}{lccc}
\hline & \multicolumn{3}{c}{ Quadrado Médio } \\
\cline { 2 - 4 } Fonte & G.L. & Ensaio 1 & Ensaio 2 \\
\hline Repetição & 2 & 3,8 & 0,8 \\
Família & 1 & $2953,9 * *$ & 2466,3 ** \\
Erro a & 2 & 11,5 & 20,7 \\
Geração (Fam.) & 10 & $781,5^{* *}$ & 582,8 ** \\
Erro b & 20 & 16,9 & 7,8 \\
\hline CV (\%) & & 9,88 & 7,08 \\
\hline
\end{tabular}

** significativo a $\mathrm{P}<0,01$ 
Tabela 2. Comprimento médio de lesão $(\mathrm{cm})$ de antracnose do colmo de seis gerações de duas famílias e estimativas de heterose e herdabilidade no sentido amplo em dois ensaios

\begin{tabular}{lcccc}
\hline & \multicolumn{2}{c}{ Das86 $\left(\mathrm{P}_{1}\right) \times$ Das21 $\left(\mathrm{P}_{2}\right)$} & \multicolumn{2}{c}{ Das86 $\left(\mathrm{P}_{1}\right) \times$ Das64 $\left(\mathrm{P}_{2}\right)$} \\
\cline { 2 - 5 } Gerações / Ensaio & Ensaio 1 & Ensaio 2 & Ensaio 1 & Ensaio 2 \\
\hline $\mathrm{P}_{1}$ & 35,4 & 46,0 & 39,9 & 38,2 \\
$\mathrm{P}_{2}$ & 23,9 & 30,1 & 16,4 & 18,5 \\
$\mathrm{~F}_{1}$ & 77,4 & 79,3 & 37,8 & 38,3 \\
$\mathrm{~F}_{2}$ & 57,2 & 40,9 & 33,5 & 32,7 \\
$\mathrm{BCP}_{1}$ & 69,6 & 51,0 & 40,3 & 35,3 \\
$\mathrm{BCP}_{2}$ & 40,2 & 30,6 & 27,1 & 24,5 \\
Heterose & 47,70 & 41,27 & 9,59 & 9,91 \\
Herdabilidade $\left(\mathrm{ha}^{2}\right)$ & 85,68 & 44,55 & 29,21 & 51,47 \\
\hline
\end{tabular}

O híbrido Das86 x Das21 foi mais suscetível do que o genitor suscetível Das86. A distribuição do comprimento de lesão na geração $F_{2}$ desta família foi para a maior suscetibilidade (dados não apresentados). Entretanto, indivíduos transgressivos para resistência foram encontrados, uma vez que $29,6 \%$ e 16,2\% dos indivíduos foram mais resistentes do que o genitor resistente Das21, respectivamente para cada ensaio. Por outro lado, o híbrido Das86 x Das64 foi tão suscetível quanto o genitor suscetível Das86 (Tabela 2). Indivíduos transgressivos para resistência também foram observados nesta família, uma vez que $15 \%$ e $21,7 \%$ dos indivíduos foram mais resistentes do que o genitor Das64, respectivamente para cada ensaio. Ao contrário da família Das86 x Das21, a distribuição do comprimento de lesão entre os indivíduos da geração $F_{2}$ aproximou-se mais da resistência, porém também foi viesada em direção a suscetibilidade (dados não apresentados). O nível de suscetibilidade dos híbridos em ambos cruzamentos sugere a presença de alelos dominantes 
para suscetibilidade (Tabela 2). As médias das gerações de retrocruzamento $\left(\mathrm{BCP}_{1}\right.$ e $\left.\mathrm{BCP}_{2}\right)$ de ambas as famílias demonstraram comportamento clássico, ou seja, quando o cruzamento envolveu o genitor suscetível (Das86) o comprimento médio de lesão da geração $\mathrm{BCP}_{1}$ foi superior. Por outro lado, quando o cruzamento envolveu o genitor resistente (Das21 ou Das64) a geração $\mathrm{BCP}_{2}$, nas duas famílias, apresentou menor comprimento de lesão (Tabela 2).

Os parâmetros genéticos foram estimados através do modelo reduzido (aditivo-dominante) para a família Das86 x Das64 e do modelo completo para a família Das86 $\times$ Das21, neste caso devido a presença de desvios significativos do modelo (Tabela 3 ). Os resultados indicaram modos distintos de herança da resistência entre estas duas famílias. Em Das86 x Das21, foram detectados efeitos significativos de dominância e da interação epistática aditivo $\mathrm{x}$ dominante no primeiro ensaio. Entretanto, no segundo ensaio, os efeitos aditivo, dominante e as duas interações epistáticas (aditivo $x$ aditivo e aditivo $x$ dominante) foram significativas (Tabela 3). Não obstante, 0 efeito predominante em ambos os experimentos foi de dominância, o qual respondeu por $41,7 \%$ e $57,9 \%$ da variância genética total. No caso das interações epistáticas, a interação aditivo $x$ dominante explicou $43,4 \%$ da variância genética para o primeiro ensaio, enquanto no segundo, a interação aditivo $x$ aditivo explicou $23,4 \%$. Os demais efeitos genéticos estimados no modelo completo foram de pequena magnitude (Tabelas 3 e 4). 
Tabela 3. Análise de variância e decomposição da variação entre gerações para comprimento médio de lesão da antracnose do colmo de duas famílias avaliadas em dois ensaios

\begin{tabular}{|c|c|c|c|c|c|}
\hline \multirow[b]{3}{*}{ Fonte } & \multirow[b]{3}{*}{ G.L. } & \multicolumn{4}{|c|}{ Quadrado Médio } \\
\hline & & \multicolumn{2}{|c|}{ Das86 x Das21 } & \multicolumn{2}{|c|}{ Das86 x Das64 } \\
\hline & & Ensaio 1 & Ensaio 2 & Ensaio 1 & Ensaio 2 \\
\hline Gerações & 6 & & & & \\
\hline Parâmetros & 5 & 3509,2 ** & 2886,8 ** & 86,81 ** & 64,60 ** \\
\hline Aditivo & 1 & 66,7 & 127,5 ** & $364,45 * *$ & 250,97 ** \\
\hline Dominante & 1 & 214,5 ** & 876,1 ** & 68,17 & 57,70 * \\
\hline Desvios $^{a}$ & 3 & - & - & 0,47 & 4,78 \\
\hline$A \times A$ & 1 & 9,67 & 353,8 ** & & \\
\hline$A \times D$ & 1 & 222,9 ** & $61,7^{*}$ & & \\
\hline Desvios & 1 & 0,21 & $94,6 * \star$ & & \\
\hline Erro (b) ${ }^{b}$ & 20 & 5,62 & 2,61 & 5,62 & 2,61 \\
\hline
\end{tabular}

${ }^{*},{ }^{\star *}$, significante a $\mathrm{P}<0,05$ e $\mathrm{P}<0,01$, respectivamente

${ }^{a}$ Desvios do modelo genético aditivo-dominante da família Das86 X Das64

${ }^{\text {b }}$ Erro da análise de variância individual 
Tabela 4. Percentagem da variação em comprimento médio de lesão da antracnose do colmo explicado pelos efeitos aditivo, dominante e interações epistáticas e desvios dos modelos para cada família nos dois ensaios

\begin{tabular}{lcccc}
\hline & \multicolumn{2}{c}{ Das86 x Das21 } & \multicolumn{2}{c}{ Das86 x Das64 } \\
\cline { 2 - 5 } Efeitos & Ensaio 1 & Ensaio 2 & Ensaio 1 & Ensaio 2 \\
\hline Aditivo & 12,98 & 8,42 & 84,2 & 80,1 \\
Dominante & 41,73 & 57,88 & 15,7 & 18,4 \\
A x A & 1,88 & 23,37 & -1 & - \\
A x D & 43,37 & 4,08 & - & - \\
Desvios & 0,04 & 6,25 & 0,1 & 1,5 \\
\hline
\end{tabular}

${ }^{1}$ interações epistáticas não estimadas

Por outro lado, na família Das86 x Das64 os efeitos genéticos aditivos foram mais proeminentes, explicando mais de $80 \%$ da variância genética total em ambos os ensaios. Além disso, efeitos reduzidos de dominância foram detectados no segundo ensaio. Nesta família, o modelo genético reduzido aditivo-dominante foi suficiente para explicar as variações encontradas entre as médias das gerações (Tabelas 3 e 4).

As estimativas de herdabilidade no sentido amplo apresentaram valores intermediários e variaram de acordo com a família e época de semeadura (Tabela 2). As estimativas de heterose foram positivas (acréscimo doença) e altamente discrepantes entre as famílias, sendo superior em Das86 x Das21 (Tabela 2).

\subsection{Discussão}

As condições experimentais de ambos os ensaios foram satisfatórias para o desenvolvimento da doença, a julgar pelos elevados valores de 
comprimento de lesão observados no híbrido suscetível Das86 x Das21. Para a avaliação da severidade desta doença, a maioria dos trabalhos utiliza uma escala de notas relativas ao número de entrenós descoloridos (Badu-Apraku et al, 1987a; Weldekidan \& Hawk, 1993; Morello, 2000) ou à área de lesão interna do colmo (Pereira et al, 1989). Neste trabalho, entretanto, o comprimento de lesão foi utilizado por ser um método direto e não subjetivo de determinação da severidade. Este método foi eficiente para discriminar indivíduos resistentes e suscetíveis dentro das gerações.

A análise de média de gerações indicou modos de herança contrastantes entre Das86 x Das21 e Das86 x Das64, os quais podem ser explicados por diferenças no background genético das linhagens resistentes (Lanza et al., 1999; Silva, 2001; Coêlho et al., 2001). O predomínio da ação gênica aditiva na família Das86 x Das64, em ambos ensaios, é um indicativo de que a seleção baseada nos indivíduos resistentes resultará em progresso genético nesta família. Estes resultados estão de acordo com Carson \& Hooker (1981) que relataram elevado efeito aditivo que explicou $90 \%$ da variação observada entre as médias das gerações. Na família Das86 x Das21, contudo, a maior parte da variância genética foi explicada pelo efeito de dominância e por interações epistáticas. Mesmo após o ajuste dos dados para o modelo completo, os desvios permaneceram significativos, indicando que a resistência é condicionada por interações epistáticas de maior ordem provavelmente envolvendo mais do que dois locos. Estas interações no entanto não foram estimadas pela necessidade de incluir mais gerações no modelo. Estes resultados estão de acordo com Callaway et al. (1980) e Badu-Apraku et al. (1987b), os quais relataram efeito de dominância e interações epistáticas neste patossistema. A elevada suscetibilidade observada no híbrido Das86 x Das21 pode advir da combinação de alelos dominantes conferindo suscetibilidade nas duas linhagens parentais nos diferentes locos.

Neste estudo, o ferimento ocasionado pela inoculação artificial dos colmos é necessário para assegurar uma distribuição uniforme do inóculo na 
unidade experimental. Este método entretanto, pode expor as plantas a infecção por patógenos secundários. Por outro lado, o desenvolvimento da antracnose do colmo é fortemente influenciada pelas condições ambientais que ocorrem durante a estação de crescimento (Keller et al., 1986). A combinação destas fontes de variação pode ajudar a explicar as discrepantes estimativas de herdabilidade entre os ensaios, o que reflete a dificuldade de trabalhar com este tipo de doença. Neste caso, uma avaliação imprecisa poderia interferir na estimativa de parâmetros genéticos (variância genética e ambiental) das famílias, resultando em estimativas de herdabilidade reduzidas. Os resultados indicaram que a resistência à antracnose do colmo é complexa e dependente da constituição genética das linhagens parentais. Entretanto, é possível obter ganhos genéticos através da seleção e da recombinação de indivíduos transgressivos observados nas gerações de segregação em ambas as famílias.

\subsection{Conclusões}

1. A análise de média de gerações evidenciou modo de herança distinto entre as duas famílias analisadas para resistência à antracnose do colmo. Em Das86 x Das21 predominaram efeitos de dominância e interações epistáticas, enquanto em Das86 x Das64 predominaram efeitos aditivos.

2. As estimativas de herdabilidade no sentido amplo foram discrepantes tanto entre as famílias como entre ensaios. Este fato reflete diferenças na constituição genética das linhagens resistentes bem como o efeito das condições ambientais na manifestação da resistência.

3. Tanto o comportamento transgressivo para maior suscetibilidade verificado entre indivíduos da geração $F_{2}$ como a alta suscetibilidade de indivíduos da geração $F_{1}$ de ambas as famílias, possivelmente se deve a 
combinação de alelos de suscetibilidade presentes no genitor resistente com aqueles do genitor suscetível.

4. As diferenças na magnitude das estimativas da heterose entre Das86 x Das21 e Das86 x Das64 são o reflexo da maior suscetibilidade da primeira família à antracnose do colmo. De fato, como observado, a heterose foi no sentido da maior suscetibilidade.

5. Progresso genético com a seleção artificial é possível desde que esta se baseie nos indivíduos transgressivos da geração $F_{2}$ de ambas as famílias analisadas. 


\section{MAPEAMENTO GENÉtICO DE GENES DE RESISTÊNCIA À ANTRACNOSE DO COLMO EM MILHO CAUSADA POR Colletotrichum graminicola (Ces.) Wils}

\section{Resumo}

Os objetivos deste trabalho foram mapear regiões genômicas associadas a resistência quantitativa (QRL ou quantitative resistance loci) à antracnose do colmo em milho e determinar os efeitos de cada QRL sobre a resistência/suscetibilidade a $C$. graminicola. Uma população $F_{2}$, oriunda do cruzamento entre duas linhagens endogâmicas, foi autofecundada para gerar famílias $F_{2: 3}$, as quais foram avaliadas para resistência em três ensaios a campo. O delineamento experimental adotado foi o látice triplo $11 \times 11$, sendo cada parcela constituída por uma fileira de $5 \mathrm{~m}$ com aproximadamente 25 plantas, totalizando 75 plantas/família em cada ensaio. Os tratamentos consistiram de 118 progênies $F_{2: 3}$ mais linhagens genitoras e híbrido. As plantas foram inoculadas artificialmente no estádio de florescimento pleno injetando-se $1 \mathrm{~mL}$ de suspensão de esporos (1,8 × $10^{5}$ conídios $\left./ \mathrm{mL}\right)$ acima do primeiro internódio do colmo visível. A avaliação dos sintomas ocorreu 30 dias após a inoculação, medindo-se o comprimento de lesão $(\mathrm{cm})$ interna dos colmos. A análise de ligação entre marcadores microssatélites e AFLPs e QRLs foi realizada através da regressão linear múltipla. Os métodos de inoculação e avaliação da doença permitiram discriminar níveis de resistência/suscetibilidade entre as progênies $F_{2: 3}$ bem como entre as linhagens genitoras. O predomínio 
de famílias $\mathrm{F}_{2: 3}$ com sintomas severos sugere efeito acentuado de dominância para suscetibilidade à antracnose do colmo neste cruzamento. As estimativas da herdabilidade variaram de 37 a $89 \%$, de acordo com o experimento, o que ilustra o acentuado efeito das condições ambientais na manifestação da doença. A proporção da variação fenotípica em resistência devida a associação de QRLs com marcadores para os três ensaios e análise conjunta variou de $44 \%$ a $63 \%$. Dos quatro modelos analisados, 9 marcadores foram identificados associados a QRLs no primeiro ensaio, 9 no segundo, 7 no terceiro e 13 na análise conjunta dos experimentos. Foram localizados alelos de resistência no genitor suscetível bem como alelos de suscetibilidade no genitor resistente. A elevada suscetibilidade das famílias $F_{2: 3}$ parece advir da combinação de alelos de suscetibilidade oriundos do genitor resistente com aqueles do genitor suscetível ou vice-versa, no caso das famílias mais resistentes. De maneira geral, foram identificados sete marcadores ligados a alelos de resistência nestes QRLS nos cromossomos 1, 4, 5, 6, 7, 8 e 9, com coeficientes de regressão parciais variando de $2,1 \%$ a $14,7 \%$. Este é o primeiro relato onde vários QRLs à antracnose do colmo foram mapeados através de marcadores moleculares.

\section{Genetic mapping of resistance genes to stalk anthracnose in maize caused by Colletotrichum graminicola (Ces.) Wils}

\section{Summary}

The objectives of this study were to map genomic regions associated with quantitative resistance loci (QRL) to stalk anthracnose in maize and to determine the effects of each QRL on resistance/susceptibility to C. graminicola. A $F_{2}$ population, originating from a cross between two inbred lines, was selffertilized to generate $F_{2: 3}$ families, which were evaluated for resistance in three 
field trials. The experimental design was a $11 \times 11$ triple lattice, and each plot consisted of a $5 \mathrm{~m}$ row with approximately 25 plants, totaling 75 plants/family in each trial. Treatments consisted of $118 \mathrm{~F}_{2: 3}$ progenies plus the parental lines and the hybrid. Plants were artificially inoculated at the flowering stage by injecting $1 \mathrm{~mL}$ of a spore suspension $\left(1.8 \times 10^{5}\right.$ conidia/mL) above the first internode of the visible stalk. The evaluation of symptoms took place 30 days after inoculation, by measuring the internal lesion lengths $(\mathrm{cm})$ in the stalks. Linkage analysis between microsatellite markers and AFLPs and QRLs was performed by means of multiple linear regressions. The inoculation and disease evaluation methods allowed to discriminate resistance/susceptibility levels between the $F_{2: 3}$ progenies, as well as between the parental lines. The high frequency of $F_{2: 3}$ families with severe symptoms suggests a marked dominance effect for susceptibility to stalk anthracnose. Heritability estimates ranged from 37 to $89 \%$, depending on the experiment, which illustrates the pronounced effect of the environment on the manifestation of the disease. The proportion of phenotypic variation in resistance due to an association of QRLs with markers in the three trials and in the joint analysis ranged from $44 \%$ to $63 \%$. Nine markers were identified associated with QRLs in the first trial, 9 in the second, 7 in the third, and 13 in the joint analysis of the experiments. Resistance alleles in the susceptible parent, as well as susceptibility alleles in the resistant parent were identified. The high susceptibility of the $F_{2: 3}$ families seems to come from a combination of susceptibility alleles originating in the resistant parent with those from the susceptible parent, or vice versa in the case of the more resistant families. In general, seven markers linked to resistance alleles were identified in these QRLs in chromosomes 1, 4, 5, 6, 7, 8, and 9, with partial coefficients of regression ranging from $2.1 \%$ to $14.7 \%$. The QRL located in chromosome four (4.10) could be the same as the one mapped by Jung et al. (1994). This is the first report where several QRLs to stalk anthracnose were mapped by means of AFLP molecular markers. 


\subsection{Introdução}

Avanços na biologia molecular efetuados nas últimas décadas resultaram no desenvolvimento de ferramentas moleculares voltadas para a análise genética de caracteres de importância agronômica em plantas. Dentre estas, destacam-se os marcadores moleculares baseados em polimorfismos de DNA, em especial os oriundos da amplificação via reação de polimerização em cadeia (PCR), como os polimorfismos de DNA amplificados ao acaso (RAPD) e os microssatélites (Williams et al., 1990). Recentemente, foram desenvolvidas novas abordagens que aliam a especificidade das enzimas de restrição com a praticidade da PCR, gerando os marcadores AFLPs ou polimorfismos de comprimento de fragmentos amplificados (Vos et al., 1995). Estas metodologias permitiram, num curto espaço de tempo, obter mapas de ligação saturados bem como mapear regiões cromossômicas contendo locos responsáveis por características quantitativas, ou QTLs, em inúmeras espécies vegetais, como cevada (Graner et al., 1994), brássicas (Slocum et al., 1990), soja (Keim et al., 1992) e milho (Coe et al., 1987; Castiglioni et al., 1999; Vuylsteke et al., 1999).

O mapeamento de QTLs de resistência quantitativa a doenças, também denominados de QRLs ("quantitative resistance loci"), tem contribuído sobremaneira para o melhor entendimento das bases genéticas da resistência quantitativa de plantas a patógenos, uma vez que a associação de marcadores a QRLs permite individualizar os efeitos fenotípicos de cada gene de resistência (Lander \& Botstein, 1989). Na última década, inúmeros genes de resistência a vários patógenos foram mapeados em milho. Os resultados indicam que esses genes estão de certa forma agrupados ao longo dos cromossomos (McMullen \& Simcox, 1995). Estes agrupamentos incluem não somente genes de resistência a determinado patógeno, como também genes de resistência a organismos não relacionados.

Existem apenas dois trabalhos que relatam a localização genômica de genes de resistência a podridões de colmo em milho. O primeiro refere-se a 
podridão do colmo causada por Gibberella zeae, no qual 6 QRLs foram mapeados nos cromossomos 1, 2, 3, 4, 5 e 10 (Pè et al., 1993). O segundo identificou um gene de resistência a Colletotrichum graminicola no cromossomo 4.08. O trabalho consistiu da avaliação de duas populações da geração $F_{2}$, através de uma escala relativa ao número de internódios descoloridos. A variação em resistência atribuída a associação marcador/QRL explicou até $73 \%$ da resistência (Jung et al., 1994). Entretanto, Carson \& Hooker (1982), utilizando translocações recíprocas, concluíram que os braços longos dos cromossomos 1,4 e 8 , e os dois braços do cromossomo 6 também devem abrigar genes de resistência a este patógeno. Neste sentido, estudos mais exaustivos de mapeamento molecular devem identificar mais QRLS a C. graminicola.

Este trabalho teve por objetivos mapear posições genômicas responsáveis pela resistência a C. graminicola e determinar os efeitos de cada QRL mapeado, visando o melhor entendimento das bases genéticas da resistência de milho a este patógeno.

\subsection{Material e Métodos}

\subsubsection{Material vegetal}

As linhagens Das21 (resistente) e Das86 (suscetível) descritas no capítulo 1 (item 3.2.1) foram cruzadas entre si a fim de gerar uma população $F_{2}$. Indivíduos da população $F_{2}$, por sua vez, foram genotipados com marcadores moleculares e autofecundados para gerar famílias $F_{2: 3}$, que foram avaliadas para resistência em ensaios a campo, conforme descrito a seguir. 


\subsubsection{Avaliação da resistência de famílias $F_{2: 3}$ a C. graminicola}

As famílias $\mathrm{F}_{2: 3}$ foram avaliadas para resistência a C. graminicola em três ensaios, semeados em 15/03, 04/11 e 04/12/2001, na Estação Experimental da Empresa DowAgroSciences Ltda. (Indianópolis, MG).

Os tratamentos constituíram 118 progênies $F_{2: 3}$, além dos genitores e da geração $F_{1}$, os quais serviram como controle. O delineamento experimental foi o de látice triplo $11 \times 11$, sendo que cada parcela foi constituída por uma linha de 5 metros com 0,90 m entre linhas com aproximadamente 25 plantas, totalizando 75 plantas/família em cada ensaio.

O cultivo do patógeno e preparo do inóculo foram realizados conforme descrito no capítulo 1 (item 3.2.2). As inoculações foram realizadas aproximadamente 60 dias após a emergência, período equivalente ao estádio de florescimento pleno da cultura (Morello, 2000). As plantas foram inoculadas injetando-se $1 \mathrm{~mL}$ de uma suspensão de $1,8 \times 10^{5}$ conídios $/ \mathrm{mL}$ com auxílio de uma seringa de uso veterinário $(50 \mathrm{~mL})$ acima do primeiro internódio do colmo visível (Figura 1). A avaliação dos sintomas ocorreu 30 dias após a inoculação. As folhas, espigas e pendões foram removidas e o colmo seccionado longitudinalmente com auxílio de uma máquina serra-fita elétrica (Figura 2). $\mathrm{O}$ comprimento da lesão $(\mathrm{cm})$ foi medido com fita métrica.

As médias ajustadas do comprimento de lesão para cada família em cada ensaio foram utilizadas para a análise de ligação entre genes de resistência e marcadores moleculares microssatélites e AFLPs.

\subsubsection{Genotipagem com marcadores moleculares}

\subsubsection{Extração de DNA}

A extração do DNA foi realizada de plantas $F_{2}$ que deram origem às famílias $F_{2: 3}$. A metodologia usada foi a de Hoisington et al. (1994), modificado 
para extração em tubos "eppendorf" de $1,5 \mathrm{~mL}$. O tecido vegetal previamente congelado em nitrogênio líquido foi macerado em cadinho de porcelana. A cada $150 \mathrm{mg}$ de tecido macerado adicionou-se $600 \mu \mathrm{L}$ de tampão de extração $1 \mathrm{X}$ CTAB $(70 \mu \mathrm{M}$ de $\mathrm{NaCl} ; 50 \mu \mathrm{M}$ EDTA pH 8,$0 ; 100 \mu \mathrm{M}$ Tris-HCl pH 7,5; $1 \% \mathrm{p} / \mathrm{v}$ CTAB, $140 \mu \mathrm{M} \beta$ mercapto-etanol). As amostras foram homogeneizadas através de suaves inversões dos tubos e incubadas em banho-maria a $65^{\circ} \mathrm{C}$ por uma hora. Após este período, as amostras foram acrescentadas de $600 \mu \mathrm{L}$ de clorofórmio/álcool-isoamílico (CIA) na proporção de 24:1 (v:v), homogeneizadas por suaves inversões do tubo por aproximadamente 5 minutos e centrifugadas em microcentrífuga à 12400rpm, por 10 minutos. Após a centrifugação, o sobrenadante foi transferido para novos tubos contendo $500 \mu \mathrm{L}$ de $\mathrm{CIA}$, os quais foram novamente invertidos e centrifugados na mesma rotação e tempo descritos anteriormente. O sobrenadante foi cuidadosamente retirado e transferido para novo tubo ao qual foi adicionado igual volume de álcool etílico absoluto resfriado a $-20^{\circ} \mathrm{C}$. Após inversão dos tubos, o DNA foi precipitado e centrifugado à $12400 \mathrm{rpm}$ por 15 minutos. Os peletes foram lavados com álcool etílico $75 \%$ por 2 minutos, álcool etílico $90 \%$ por 2 minutos e álcool etílico absoluto por 2 minutos. Após secagem do DNA a temperatura ambiente, o mesmo foi ressuspendido em $50 \mu \mathrm{L}$ de TE pH 8,0 (10mM de Tris- $\mathrm{HCl}$ e $1 \mathrm{mM}$ de EDTA) e tratado com $1 \mu \mathrm{L}$ de RNAse $(1 \mathrm{mg} / \mathrm{mL})$ por $2 \mathrm{~h}$ a $37^{\circ} \mathrm{C}$.

Alíquotas de $1 \mu \mathrm{L}$ das amostras de DNA foram quantificadas em gel de agarose 1\% (Gibco BRL), corados com brometo de etídio $(10 \mathrm{mg} / \mathrm{mL}$ ) e fotodocumentados com aparelho ImageMaster ${ }^{\circledR}$ VDS (Pharmacia Biotech). A concentração das alíquotas foi estimada visualmente comparando suas intensidades de fluorescência com aquelas de alíquotas de DNA fago $\lambda$ diluído nas concentrações de 50, 100, 200 e 250ng/ $\mu \mathrm{L}$. Após as estimativas das concentrações de DNA de cada amostra, as mesmas foram diluídas para uma concentração aproximada de $10 \mathrm{ng} / \mu \mathrm{L}$, no caso de marcadores microssatélites, e $65 \mathrm{ng} / \mu \mathrm{L}$ no caso de marcadores AFLPs. 


\subsubsection{Genotipagem com marcadores microssatélites}

Inicialmente, 165 locos microssatélites, distribuídos pelos 10 cromossomos de milho, foram testados nas linhagens genitoras e no híbrido a fim de selecionar locos polimórficos entre as linhagens genitoras. Estes locos foram escolhidos pela qualidade dos produtos amplificados segundo resultados de Ogliari (1999), Morello (2000), Brunelli et al. (2002) e Lopes (2003). Dos locos polimórficos, aproximadamente de 2 a 4 foram selecionados por cromossomo a fim de genotipar os indivíduos $\mathrm{F}_{2}$.

As reações de amplificação foram realizadas em termociclador $\mathrm{MJ}$ Research $^{\circledR}$ PTC-200 (MJ Research, Alameda, CA, EUA) baseadas nos protocolos de Senior et al. (1996) e Ogliari et al. (2000). Após a amplificação, as amostras receberam $5 \mu \mathrm{L}$ de tampão de carregamento $(500 \mu \mathrm{L}$ de EDTA 0,5M $\mathrm{pH} 8,0,500 \mu \mathrm{L}$ de glicerol $99 \%$ e $2,16 \mathrm{mg}$ de bromofenol) e os fragmentos amplificados foram resolvidos por eletroforese em gel de agarose 3,5\% (Gibco BRL) em tampão TBE 1X por aproximadamente 3 horas a 80V. Os géis foram visualizados sobre luz ultravioleta em transiluminador UV e fotodocumentados com aparelho ImageMaster ${ }^{\circledR}$ VDS (Pharmacia Biotech).

\subsubsection{Genotipagem com marcadores AFLPs}

Inicialmente, foram testadas 100 combinações de primers EcoRI + Msel para selecionar aquelas que resultaram em melhor amplificação de alelos marcadores e também maior número de locos polimórficos entre as linhagens genitoras. Destas, 17 combinações foram escolhidas para genotipar a população $F_{2}$.

A metodologia de amplificação de AFLPs consistiu de quatro etapas: 1) digestão do DNA genômico com as enzimas de restrição, 2) ligação dos adaptadores das enzimas de restrição aos fragmentos gerados pela digestão, 3) pré-amplificação dos fragmentos com primers contendo um nucleotídeo seletivo na posição 3' e 4) amplificação seletiva com primers contendo três 
nucleotídeos seletivos na posição 3'. A descrição detalhada da metodologia seguiu a descrita por Vos et al. (1995) com as adaptações de Lopes (2003).

Os géis de AFLP foram preparados com $120 \mathrm{~mL}$ de solução de matriz (acrilamida/bisacrilamida 6\%, uréia 7,5M e tampão 1X TBE), 120 $\mu \mathrm{L}$ de TEMED e $800 \mu \mathrm{L}$ de persulfato de amônio $10 \%$. O gel foi submetido a uma pré-corrida por 1 hora a 80W de potência. Antes da corrida, as amostras foram acrescentadas de $8,0 \mu \mathrm{L}$ de tampão formamida $2 \mathrm{X}$ (formamida 98\%, EDTA 10mM, pH 8,0, azul de bromofenol 0,002\% (p/v) e xileno cianol 0,002\% p/v) e desnaturadas a $95^{\circ} \mathrm{C}$ por 5 minutos. Para a corrida eletroforética utilizou-se 0 sistema "Sequi-Gen GT" (Biorad) em tampão TBE 1X numa potência constante de $80 \mathrm{~W}$ por 3 horas e 30 minutos.

A metodologia para a coloração dos géis com nitrato de prata foi baseada no protocolo de Creste et al. (2001). Após a completa secagem do gel na placa de vidro, procedeu-se a análise dos fragmentos amplificados sobre transiluminador de luz branca. A genotipagem foi baseada na presença (escore 1) ou ausência (escore 0 ) de determinado fragmento marcador para cada indivíduo analisado. Os tamanhos dos fragmentos amplificados foram obtidos através da regressão entre a distância $(\mathrm{cm})$ dos fragmentos do marcador $50 \mathrm{pb}$ (Promega) e a distância $(\mathrm{cm})$ do fragmento de DNA em análise. Locos marcadores foram denominados segundo Castiglioni et al. (1999). Por exemplo, o loco E4462470 corresponde ao fragmento amplificado pela combinação de primers das enzimas Eco44 + Mse62 com peso molecular de aproximadamente 470pb.

\subsubsection{Análises estatísticas}

Os comprimentos médios das lesões no colmo das famílias $F_{2: 3}$ foram submetidos a análise de variância para cada época de semeadura, considerando o modelo aleatório de Cochran \& Cox (1966): 


$$
Y_{i j k}=\mu+t_{i}+r_{j}+b_{k(j)}+e_{i j k}
$$

onde:

$Y_{\mathrm{ijk}}$ : é o valor observado do tratamento $\mathrm{i}(\mathrm{i}=1,2, \ldots, 121)$, no bloco incompleto $\mathrm{k}$ $(k=1,2, \ldots, 11)$, na repetição j $(j=1,2,3)$;

$\mu$ : é uma constante inerente a todas as observações;

$\mathrm{t}_{\mathrm{i}}$ : é o efeito do tratamento i;

$\mathrm{r}_{\mathrm{j}}$ : é o efeito da repetição j;

$b_{k(j)}$ : é o efeito do bloco incompleto $k$ dentro da repetição j;

$\mathrm{e}_{\mathrm{ijk}}$ : é o erro aleatório associado à observação $Y_{\mathrm{ijk}}$

De posse dos resultados das análises individuais de variância, verificou-se a pressuposição de homogeneidade de variâncias pelo método prático de Gomes (1990), o qual baseia-se na divisão do maior quadrado médio do resíduo pelo menor quadrado médio do resíduo das análises individuais. Se o valor resultante for inferior a 7, infere-se homogeneidade de variâncias, o que possibilita a análise conjunta dos experimentos. Neste caso, o modelo estatístico da análise conjunta foi:

$$
Y_{i j k l}=\mu+r_{j(l)}+b_{k(j)}+t_{i}+c_{l}+(t c)_{j l}+e_{i j k l}
$$

onde:

$Y_{\mathrm{ijkl}}$ : é o valor do tratamento $\mathrm{i}(\mathrm{i}=1,2, \ldots, 121)$, na repetição $\mathrm{j}(\mathrm{j}=1,2,3)$, no bloco incompleto $k(k=1,2, \ldots, 11)$, na época I $(l=1,2,3)$;

$\mu$ : é uma constante inerente a todas as observações;

$r_{j(l)}$ : é o efeito da repetição j dentro da época I;

$b_{k(1)}$ : é o efeito do bloco incompleto $k$, dentro da repetição j dentro da época l;

$\mathrm{t}_{\mathrm{i}}$ : é o efeito do tratamento $\mathrm{i}$;

$\mathrm{c}_{\mathrm{l}}$ : é o efeito da época l;

(tc)j: é o efeito da interação tratamento i com a época l;

$\mathrm{e}_{\mathrm{ijk} \mathrm{k}}$ : é o erro aleatório associado à observação $Y_{\mathrm{ijkl}}$ 
As análises de variância individuais e conjunta foram realizadas com o auxílio do programa SAS (SAS Institute, 1993). As médias ajustadas das famílias $F_{2: 3}$ para cada ensaio, bem como aquelas obtidas pela análise conjunta foram submetidas ao teste de comparação múltipla de médias de Scott-Knott através do programa GENES (Cruz, 1997). As estimativas de herdabilidade no sentido amplo foram calculadas segundo Hallauer \& Miranda Filho (1988).

No caso dos ensaios individuais:

$$
h^{2}{ }_{a}=\left(\sigma_{G}^{2}\right) /\left(\sigma_{F}^{2}\right)
$$

onde

$\sigma^{2}{ }_{G}$ é a variância genética estimada por:

$$
\sigma^{2}{ }_{G}=\left(Q M_{\text {Progênie }}-\mathrm{QM}_{\text {Resíduo }}\right) / r(k / k+1)
$$

$\sigma^{2}{ }_{F}$ é a variância fenotípica estimada por:

$$
\sigma^{2}=\left[Q M_{\text {Resíduo }} / r(k / k+1)\right]+\sigma_{G}^{2}
$$

k é o número de sub-blocos

No caso da análise conjunta utilizou-se a fórmula:

$$
h^{2}{ }_{a}=\left[\sigma_{G}^{2} /\left(\sigma^{2}{ }_{G}+\sigma^{2}{ }_{G E} / l_{e}+\sigma^{2} / r e\right)\right]
$$

onde

$\sigma_{G E}^{2}$ é a variância genótipo x ambiente, "e" o número de ensaios e "r" o número de repetições.

Testes de distorção de segregação Mendeliana foram realizados para todos os locos microssatélites e AFLPs genotipados na população de mapeamento. Para os marcadores microssatélites, testou-se a hipótese de segregação mendeliana esperada para um marcador co-dominante em uma geração $F_{2}$ (1:2:1). No caso dos marcadores AFLPs, a hipótese esperada de 
segregação para os marcadores foi de 3 (presença) : 1 (ausência). Devido ao grande número de testes independentes, o nível de significância global foi ajustado usando-se a correção de Bonferroni. Quando são realizados $\mathrm{n}$ testes independentes, a probabilidade de erro tipo I do experimento é dado por:

$$
\alpha=1-\left(1-\alpha_{T}\right)^{n}
$$

Assim, em cada teste deve-se tomar, para um dado $\alpha$ :

$$
\alpha_{T}=1-(1-\alpha)^{1 / n} \cong \alpha / \mathrm{n} \text { (Correção de Bonferroni) }
$$

Neste estudo, utilizou-se um $\alpha=5 \%$ de probabilidade com $n=319$ marcadores (AFLPs + Microssatélites), portanto, realizou-se o teste de quiquadrado com $\alpha_{T}=0,016 \%$.

\subsubsection{Análise de ligação entre marcadores e construção de mapa genético}

Locos microssatélites e AFLPs que apresentaram segregação mendeliana foram utilizados para a construção de um mapa de ligação com auxílio do programa MAPMAKER versão 3.0 (Lander et al., 1987). A construção dos grupos de ligação baseou-se no comando "group" utilizando-se um "lod score" (LOD) de 4,0 (método da máxima verossimilhança), freqüência máxima de recombinação $\theta=0,40$ e função de mapeamento de Haldane. Após a obtenção dos grupos de ligação, os marcadores dentro de cada grupo foram ordenados pelo comando "order" com um LOD maior que 3,0. Para garantir a correta ordenação dentro do grupo, utilizou-se o comando "ripple", confirmando assim a ordem dos marcadores.

\subsubsection{Mapeamento de QRLs pela análise de regressão linear múltipla}

Inicialmente, todos os locos microssatélites e AFLPs (sem distorção) genotipados na população foram submetidos a uma análise de regressão linear simples (Edwards et al.,1987). As médias ajustadas do comprimento de lesão 
de cada família $F_{2: 3}$ para os três ensaios de campo, bem como as da análise de variância conjunta foram consideradas como variáveis dependentes e os genótipos em locos marcadores como variáveis independentes. Este processo permitiu selecionar apenas as marcas significativamente $(P<0,05)$ associadas a resistência nas análises de cada ensaio bem como na análise conjunta dos dados.

A análise de regressão linear múltipla foi realizada apenas para o conjunto de locos selecionados pela análise de regressão linear simples nos respectivos ensaios (Edwards et al.,1987). Em cada ensaio, foram construídos modelos com os marcadores moleculares que permaneceram na análise de regressão múltipla pelo processo "stepwise" de seleção de variáveis regressoras (Draper \& Smith, 1981). Neste procedimento, utilizou-se um nível de significância de 5\% para a entrada e saída das marcas no modelo.

\subsection{Resultados e Discussão}

\subsubsection{Avaliação de progênies $F_{2: 3}$ para resistência a $C$. graminicola}

O mapeamento de genes de resistência relatado neste trabalho foi feito com base na avaliação de 118 progênies $F_{2: 3}$, linhagens genitoras e geração $F_{1}$ em três ensaios de campo. Estas dimensões experimentais são inéditas na literatura para este patossistema. Além disto, a metodologia de avaliação foi baseada na medição direta do comprimento de lesão de cada planta e não estimada indiretamente por meio de escala de notas como usualmente é feito. Os métodos de inoculação e avaliação empregados foram eficientes para discriminar as progênies $F_{2: 3}$ e as gerações parentais quanto ao grau de resistência/suscetibilidade.

As análises de variância de cada experimento revelaram diferenças significativas $(P<0,01)$ entre tratamentos (progênies, linhagens genitoras e $F_{1}$ ) 
em ambos os ensaios. Os contrastes ortogonais entre progênies $\left(F_{2: 3}\right)$, testemunhas (Das21, Das86 e $F_{1}$ ) e progênies $x$ testemunhas também foram significativos $(P<0,01)$, exceto para o último caso no primeiro e segundo ensaio (Tabela 5). Os coeficientes de variação experimental podem ser considerados adequados, tratando-se de ensaio de inoculação artificial sob condição de campo (Paterniani et al., 2000). As estimativas de herdabilidade no sentido amplo variaram de 0,37 a 0,89 (Tabela 5). Estes resultados estão de acordo com as estimativas obtidas no estudo de herança no capítulo 1. Estimativas de mesma magnitude também foram relatadas em estudos de outros patossistemas de milho (Freymark et al., 1994; Holland et al., 1998; Lübberstedt et al., 1998; Kerns et al., 1999; Duble et al., 2000; George et al., 2003).

A análise de variância conjunta revelou interação significativa entre época e tratamentos $(P<0,01)$, indicando que a resistência/suscetibilidade a $C$. graminicola nesta população $F_{2: 3}$ foi influenciada pelas condições ambientais inerentes a cada ensaio, sugerindo que diferentes genes podem estar sendo expressos nos ambientes analisados. A exemplo das análises individuais, os contrastes entre progênies, testemunhas $\left(P_{1}, P_{2}\right.$ e $\left.F_{1}\right)$ e progênies $x$ testemunhas também foram significativos $(P<0,01)$. $O$ contraste significativo entre progênies confirma que houve segregação para resistência/ suscetibilidade a C. graminicola nos ensaios (Tabela 6). 
Tabela 5. Resumo das análises de variância do comprimento médio de lesão $(\mathrm{cm})$ de C. graminicola avaliado em progênies $F_{2: 3}$, linhagens parentais e híbrido em três ensaios. Indianópolis (MG)

\begin{tabular}{lcccc}
\hline & & \multicolumn{3}{c}{ Quadrado Médio } \\
\cline { 3 - 5 } Fonte Variação & G.L. & Ensaio 1 & Ensaio 2 & Ensaio 3 \\
\hline Repetição & 2 & $1877,6 * *$ & 198,2 & 1566,6 ** \\
Bloco(Rep.) & 30 & 68,4 & 137,5 & 40,6 \\
$\quad$ Trat. Ajus. & 120 & $124,8 * *$ & $1054,9 * *$ & 138,7 ** \\
$\quad$ Prog. Ajus. & 117 & $115,1 * *$ & $1037,1 * *$ & 103,6 ** \\
$\quad$ Test. Ajus. & 2 & $603,6 * *$ & $2624,4 * *$ & $1481,3 * *$ \\
$\quad$ Prog. X Test. & 1 & 195,8 & 39,6 & $1233,0 * *$ \\
Resíduo Intrabloco & 210 & 72,04 & 109,45 & 43,27 \\
\hline Média Trat. & & 33,47 & 34,68 & 34,51 \\
Média Prog. & & 33,67 & 34,58 & 34,18 \\
Média Test. & & 37,45 & 38,80 & 47,38 \\
Valor mínimo & & 1,30 & 1,43 & 15,73 \\
Valor máximo & & 65,94 & 103,06 & 77,35 \\
Cve (\%) & & 25,36 & 30,16 & 19,06 \\
$\mathrm{~h}^{2}$ a & & 0,37 & 0,89 & 0,58 \\
\hline
\end{tabular}

** significativo a $\mathrm{P}<0,01$ 
Tabela 6. Resumo da análise de variância conjunta de três experimentos para o comprimento médio de lesão $(\mathrm{cm})$ de $C$. graminicola avaliado em progênies $F_{2: 3}$, linhagens parentais e híbrido. Indianópolis (MG)

\begin{tabular}{lcc}
\hline Fonte Variação & G.L. & Quadrado Médio \\
\hline Época & 2 & 156,4 \\
Rep(Época) & 6 & 1214,2 ** \\
Bloco(Época x Rep.) & 90 & 82,2 \\
Época x Tratamento & 240 & 289,0 ** \\
Tratamento & 120 & 727,4 ** \\
$\quad$ Progênie & 117 & 662,2 ** \\
$\quad$ Testemunha & 2 & 4346,6 ** \\
$\quad$ Prog. x Test. & 1 & $1047,9 * *$ \\
Resíduo Intrabloco & 630 & 74,92 \\
\hline Média Tratamento & & 34,22 \\
Média Progênie & & 34,04 \\
Média Testemunha & & 41,21 \\
Valor mínimo & & 1,30 \\
Valor máximo & & 103,06 \\
Cve (\%) & & 25,29 \\
$\mathrm{~h}^{2}$ a & & 0,63 \\
\hline
\end{tabular}

** significativo a $\mathrm{P}<0,01$

A distribuição de freqüência dos comprimentos médios de lesão das famílias $F_{2: 3}$ indicou que indivíduos $F_{1}$ foram mais suscetíveis que os das demais gerações, sugerindo acentuado efeito de dominância para suscetibilidade neste cruzamento (Figura 3). De fato, a análise de média de gerações relatada no primeiro capítulo confirma o predomínio de efeitos de dominância e interações epistáticas (aditivo $x$ aditivo e aditivo $x$ dominante) para suscetibilidade neste cruzamento. Nos três ensaios, a linhagem parental Das21 
foi mais resistente que Das86, com comprimento médio de lesão variando de $9 \mathrm{~cm}$ a $27,1 \mathrm{~cm}$. Em Das86, as médias variaram de $30,5 \mathrm{~cm}$ a $41,7 \mathrm{~cm}$ (Tabela 7; Anexo). Os resultados do comprimento de lesão obtidos no primeiro ensaio não permitiram uma clara discriminação entre as progênies $F_{2: 3}$. Este fato pode estar relacionado a dois fatores: 1) a semeadura foi realizada fora do período normal de cultivo, com elevada temperatura e déficit hídrico, condições não ideais para a colonização deste patógeno (Hammerschimidt \& Nicholson, 1977; Schall et al., 1980) e 2) pode ter havido diferenças entre parcelas no que toca a fertilidade do solo, uma vez que a área experimental foi cultivada pela primeira vez.

Apesar da suscetibilidade observada para a maioria das progênies $F_{2: 3}$, foram encontradas famílias resistentes superando o genitor resistente nos três ensaios. Este comportamento transgressivo para resistência ou para suscetibilidade pode ser devido a combinação de alelos de resistência presentes nas linhagens genitoras, conforme hipótese já levantada quando da análise do modo de herança da resistência neste cruzamento descrito no capítulo 1. 

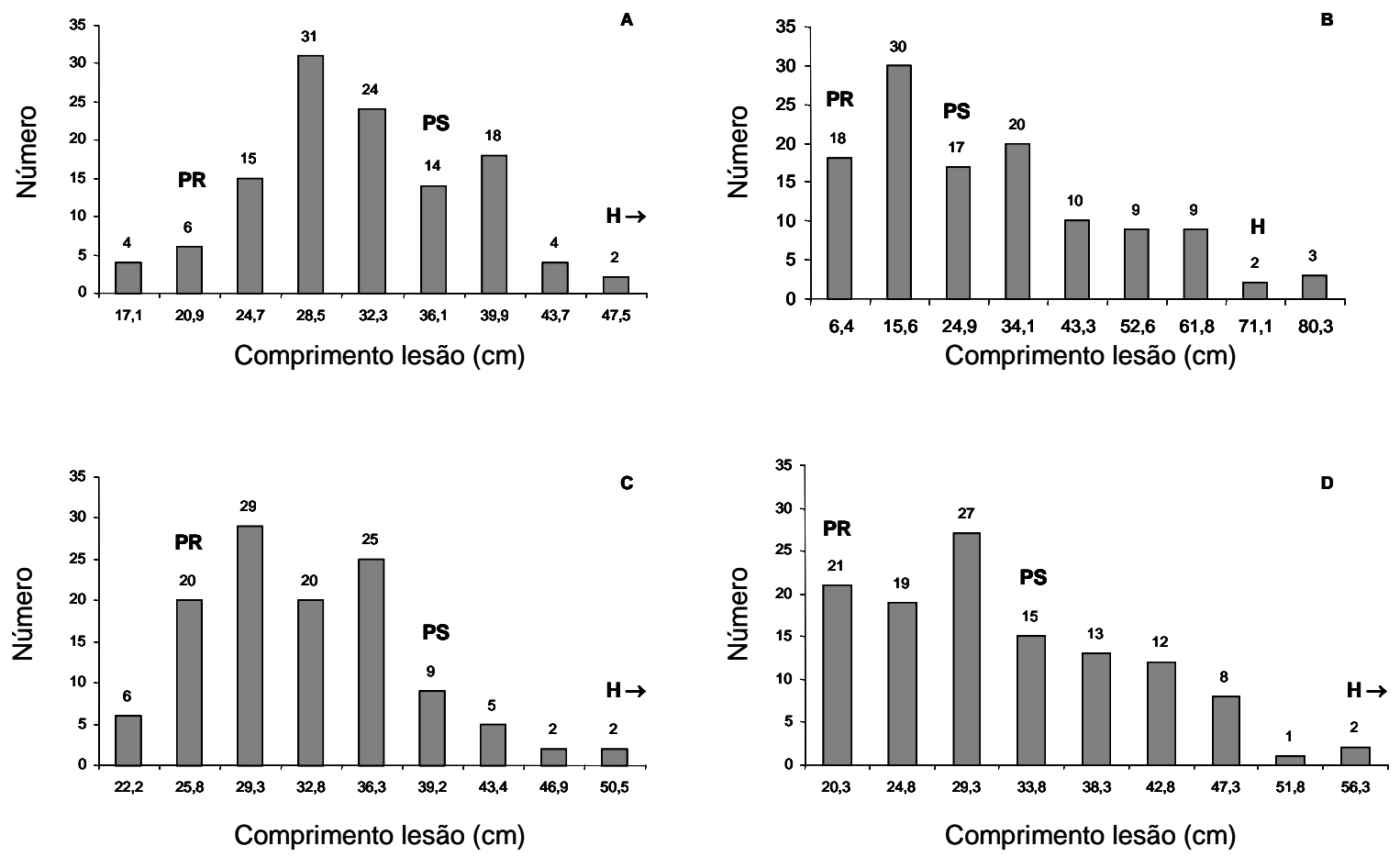

Figura 3 - Distribuição das médias ajustadas do comprimento de lesão entre as progênies $F_{2: 3}$ do cruzamento Das21 x Das86. A) distribuição de freqüência do primeiro ensaio, B) segundo ensaio, C) terceiro ensaio e D) análise conjunta. $P R=$ parental resistente, $P S=$ parental suscetível e $\mathrm{H}=$ geração $\mathrm{F}_{1}$ 


\subsubsection{Análise de marcadores microssatélites}

Inicialmente, 165 locos microssatélites foram analisados nas linhagens genitoras e geração $F_{1}$ com 0 intuito de selecionar aqueles polimórficos e com adequado padrão de amplificação via PCR (Tabela 8; Anexo). Estes locos foram escolhidos por amostrar todos os cromossomos do milho. Em média, foram testados aproximadamente 19 locos/cromossomo, exceto para os cromossomos 3, 8 e 10 (Tabela 9; Anexo).

Entre os locos analisados, 84 não foram informativos, ou seja, não revelaram polimorfismos (alelos distintos) entre as linhagens genitoras, 16 não foram amplificados devido a problemas na PCR e 65 foram polimórficos (Tabela 9; Anexo e Figura 4). Entre as linhagens de milho analisadas em trabalhos realizados no Laboratório de Genética Molecular da Seção de Fitopatologia da ESALQ/USP, Das21 e Das86 foram as mais polimórficas (Ogliari, 1999; Morello, 2000; Brunelli, 2000; Lopes, 2003). Estes resultados possivelmente se devem ao fato das mesmas pertencerem a grupos heteróticos distintos, Suwan DMR e Amarillo Dentado, respectivamente (Lanza et al., 1999). Dos locos polimórficos, 26 foram analisados em todos os indivíduos da população de mapeamento e utilizados na construção do mapa genético. 


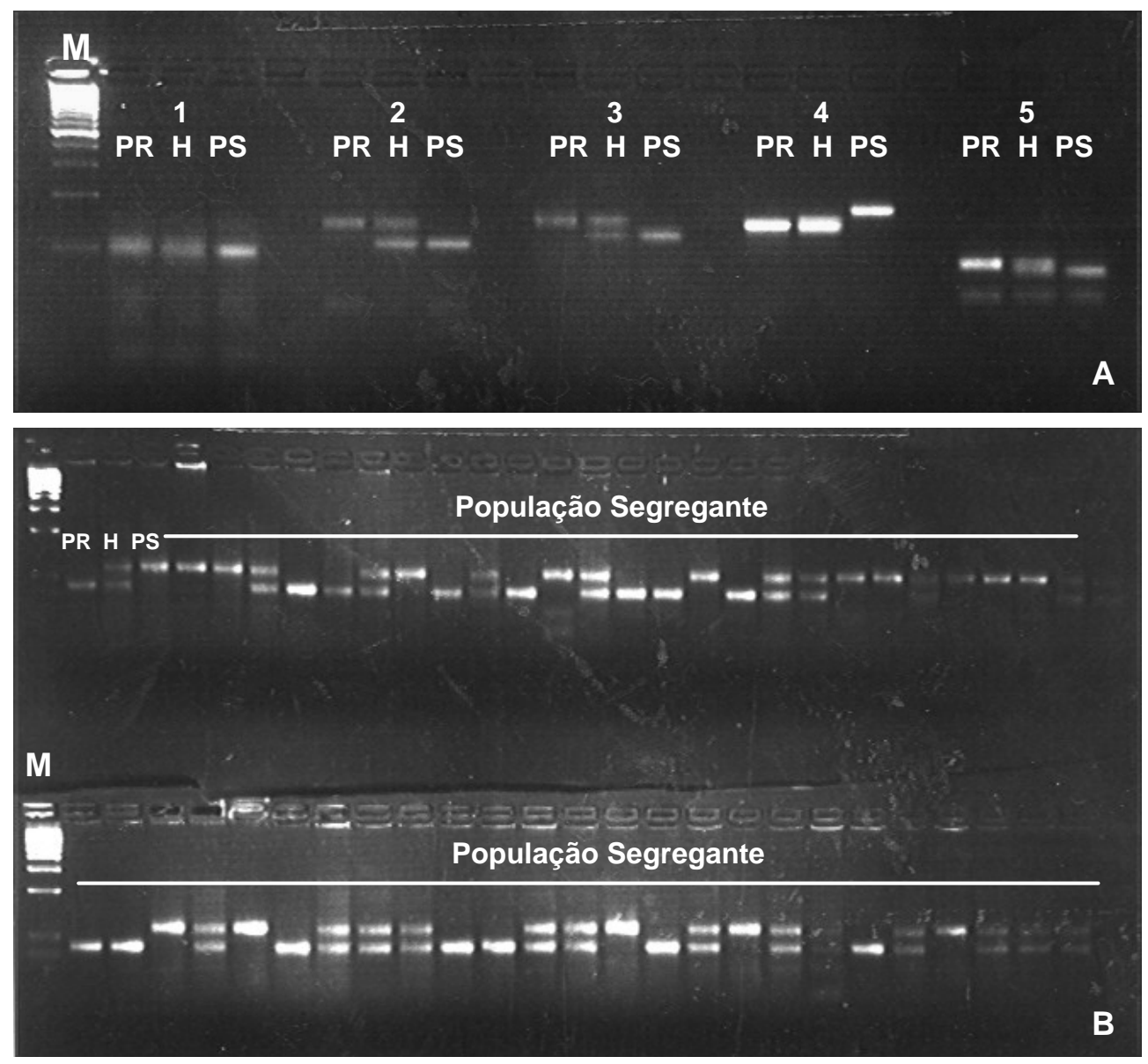

Figura $4-$ Gel de agarose 3,5\%. A) Screening de locos microssatélites, 1bnlg657- monomórfico, 2- bnlg434- polimórfico, 3- bnlg339polimórfico, 4- bnlg161- polimórfico, 5- phi061- polimórfico. B) Genotipagem de indivíduos da população segregante $F_{2}$ com 0 primer SSR bnlg131. $\mathrm{M}=$ marcador molecular $50 \mathrm{pb}, \mathrm{PR}=$ parental resistente, $\mathrm{H}=$ geração $\mathrm{F}_{1}, \mathrm{PS}=$ parental suscetível 


\subsubsection{Análise de marcadores AFLPs}

Para a análise de marcadores AFLPs avaliou-se 100 combinações de primers das enzimas EcoRI + Msel nas linhagens genitoras e híbrido (Tabela 10; Anexo). As combinações testadas geraram 5458 fragmentos marcadores, sendo que destes 1353 foram polimórficos entre as linhagens genitoras, o que equivale a um polimorfismo médio de $24,8 \%$ por combinação de primers. Entretanto, esse nível de polimorfismo variou em função da combinação utilizada. A combinação E39/M56 (E-AGA/M-CGC), por exemplo, apresentou o menor nível, com apenas 6,9\%, ao passo que E44/M61 (E-ACA/M-CTG) apresentou nível de 36,9\% (Tabela 10; Anexo). Destas combinações, foram escolhidas 17 que apresentaram maior nível de polimorfismo aliado à qualidade dos fragmentos amplificados pela PCR. Estas combinações resultaram na amplificação de 843 fragmentos, sendo que destes 284 foram polimórficos $(33,7 \%)$ (Tabela 10; Anexo). Este polimorfismo foi muito superior ao encontrado por Castiglioni et al. (1999), os quais relataram nível médio de polimorfismo de 18,5\% a partir de 11 combinações de primers EcoRI + Msel numa população oriunda do cruzamento de linhagens temperadas pertencentes a grupos heteróticos distintos. Este baixo polimorfismo pode ser atribuído a ausência de seleção prévia de combinações de primers de alto nível de polimorfismo entre os genitores da população. Ao contrário de Castiglioni et al. (1999), mas de forma similar a este trabalho, Vuylsteke et al. (1999), estudando os mesmos grupos heteróticos temperados em duas populações $\left(F_{2}\right.$ e linhagens puras recombinantes), obtiveram níveis de polimorfismo variando de $35,7 \%$ a $36,3 \%$, respectivamente, em 41 combinações de primers EcoRI + Msel. Aparentemente, com base nos resultados obtidos neste trabalho e àqueles de Vuylsteke et al. (1999), parece existir uma semelhança no nível de polimorfismo observado entre grupos heteróticos tropicais (Amarillo Dentado e Swan DMR) e grupos heteróticos temperados (Stiff Stalk Synthetic e Lancaster Sure Crop) para os marcadores AFLPs. 
Uma comparação interessante a respeito do nível de polimorfismo entre marcadores microssatélites e AFLPs é que, num primeiro momento, os microssatélites foram mais polimórficos que os AFLPs $(39,4 \%$ e $24,8 \%$, respectivamente). Entretanto, o número de locos marcadores obtidos com a técnica AFLP foi muito superior, gerando em média 13,5 locos polimórficos/combinação de primers (Tabela 11; Figura 5). Isto ilustra a capacidade desta tecnologia em gerar grande número de fragmentos polimórficos quando comparado a outros marcadores moleculares, o que corrobora os resultados de Pejic et al. (1998) que relataram que marcadores AFLPs geram em média 10 vezes mais alelos informativos/reação do que outros marcadores moleculares (SSRS, RAPDs e RFLPS). Uma grande vantagem do elevado número de locos informativos/reação de PCR é que uma rápida saturação das regiões cromossômicas pode ser obtida a um baixo custo (Vos et al., 1995; Ajmone-Marsan et al.,1998; Melchinger et al.,1998; Castiglioni et al., 1999; Vuylsteke et al., 1999).

Tabela 11. Nível de polimorfismo genético entre as linhagens genitoras Das21 e Das86 para marcadores moleculares microssatélites e AFLPS

\begin{tabular}{lcccc}
\hline & \multicolumn{2}{c}{ Microssatélites } & \multicolumn{2}{c}{ AFLPs } \\
\cline { 2 - 5 } & Número & $\%$ & Número & $\%$ \\
\hline Polimórfico & 65 & 39,4 & 1353 & 24,8 \\
Monomórfico & 84 & 50,9 & 4100 & 75,1 \\
Não Amplificou & 16 & 9,7 & 5 & 0,01 \\
$\mathrm{~N}^{0}$ locos/marcador & 01 & - & 13,5 & - \\
\hline Total & $165 *$ & 100 & $(100) 5458$ ** & 100 \\
\hline
\end{tabular}

* número de primers SSR testados entre os genitores Das21 e Das86

** número de fragmentos obtidos com a combinação EcoRI + Msel 


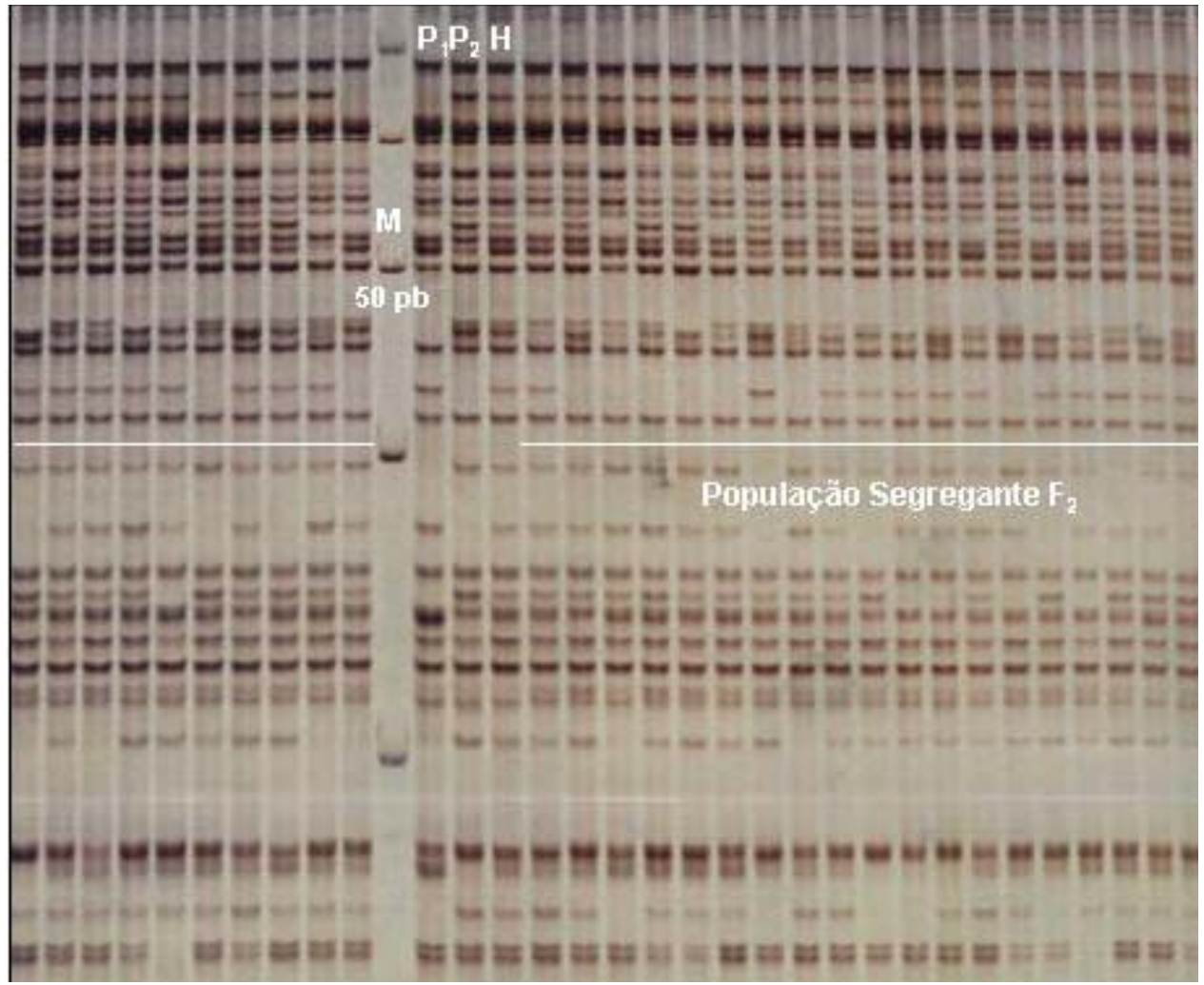

Figura 5 - Gel de AFLP mostrando a presença e ausência do fragmento para o genitor resistente $\left(P_{1}\right)$, genitor suscetível $\left(P_{2}\right)$ e híbrido $(H)$ bem como sua segregação em parte dos indivíduos da geração $F_{2}$

\subsubsection{Construção do mapa genético}

A maioria $(88,7 \%)$ dos locos marcadores apresentaram segregação mendeliana, similar ao observado por Castiglioni et al. (1999). Dos 310 locos marcadores polimórficos, 275 foram utilizados para a construção do mapa de ligação, uma vez que apenas 32 fragmentos AFLPs e 3 locos SSR apresentaram distorção de segregação mendeliana (dados não apresentados). Das 275 marcas utilizadas, 252 foram agrupadas em 18 grupos de ligação utilizando como critério de agrupamento "lod score" (LOD) de 4,0 e freqüência máxima de recombinação $\theta=0,40$. Dentre os 18 grupos, apenas 10 
apresentaram configuração cromossômica baseado no número de marcas associadas, presença de marcadores microssatélites e comprimento do grupo (Figura 6). Os 8 grupos restantes, com média de 2 a 3 marcas, possivelmente consistem de pontas de grupos de ligação que não foram associados aos demais, provavelmente pela baixa saturação do mapa de ligação. De fato, locos AFLPs oriundos da combinação de primers EcoRl + Msel amostram preferencialmente regiões centroméricas dos cromossomos (Castiglioni et al., 1999; Vuylsteke et al., 1999). A estratégia de utilizar marcadores microssatélites como "âncoras" genéticas nos grupos de ligação possibilitou que os mesmos fossem associados aos cromossomos de milho, permitindo também a localização cromossômica dos locos AFLPs (Figura 6).

Das marcas agrupadas, 157 (74\%) foram ordenadas nos 10 cromossomos, utilizando como critério de ordenação LOD >3,0. O número de marcas ordenadas variou de 10 no cromossomo 1 até 24 no cromossomo 4 , com média de 16 marcas/cromossomo (Tabela 12). O comprimento total do mapa de ligação foi de $1482 \mathrm{cM}$. Já o comprimento dos grupos variou de $81 \mathrm{cM}$ a 256 cM. No trabalho de Vuylsteke et al. (1999), duas populações oriundas do cruzamento de linhagens temperadas de milho utilizando 220 indivíduos $\left(F_{2}\right)$ e 208 indivíduos (RILs) foram genotipadas com 1402 e 1723 locos marcadores, respectivamente. Os autores obtiveram mapas de ligação com comprimento total de $1375,6 \mathrm{cM}$ e $1178,1 \mathrm{cM}$; desta forma, estes mapas, ainda que com um número maior de locos marcadores, foram inferiores em comprimento (cM) ao obtido neste trabalho. No entanto, os níveis de saturação dos mapas foram superiores, a julgar pela distância média entre marcadores. Já Castiglioni et al. (1999) obtiveram um mapa de ligação com uma cobertura de 2057 cM, com marcadores distribuídos a cada 6,6 cM. Este resultado pode ser atribuído ao tamanho da população genotipada (229 famílias), permitindo maior amostragem dos gametas e, conseqüentemente, aumentando a probabilidade na detecção de eventos de recombinação. Neste trabalho, a distância média entre marcas 
foi de 9,4 cM, o que propiciou um razoável nível de saturação do genoma, exceto para o cromossomo 6, onde o intervalo foi de 14,5 cM (Tabela 12).

Aparentemente, parece existir uma especificidade dos marcadores gerados por certas combinações de primers em relação à localização dos fragmentos nos grupos de ligação (cromossomos). Por exemplo, das 17 combinações analisadas, 8 delas produziram fragmentos agrupados em mais de 6 cromossomos, corroborando os resultados apresentados por Castiglioni et al. (1999). Por outro lado, a combinação AGG/CAA gerou 8 marcadores polimórficos mas destes, apenas um único fragmento foi mapeado (Tabela 13; Anexo). Neste sentido, trabalhos futuros devem levar em consideração não só o número mas também a distribuição dos marcadores gerados pelas diferentes combinações de primers a fim de obter mapas com boa cobertura genética. 
C 1

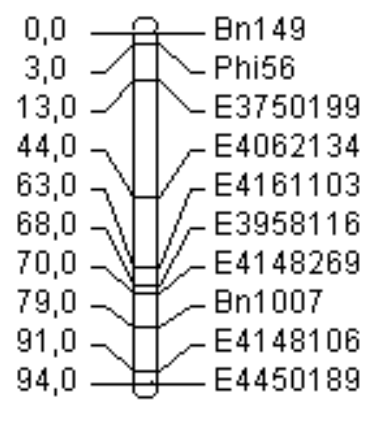

C 5

$0,0-?$ E406264

26,0
38,0 $r_{r^{\mathrm{E} 3648196}}^{\mathrm{En557}}$

$41,07 / r^{\mathrm{E} 4450494}$

$43,0, \sqrt{-E 4062299}$

$44,0-1=-E 4450132$

46,0 - $-E 446280$

$\left.\begin{array}{l}48,0- \\ 52,0\end{array}\right] \longrightarrow$ E3959250

72,0 - E4062230

$80,0-10375090$

$108,0-r^{\mathrm{E} 3648130}$

$111,0-{ }_{-10 n} 278$

$115,0-1 /{ }^{\mathrm{E} 3959272}$

116,0 - $-E 3750147$

$118,0-Z 3260217$

$125,0-\mathrm{D} 2260957$

$139,0 \smile$ E4450106

C 9

$0,0-2$ Phi65

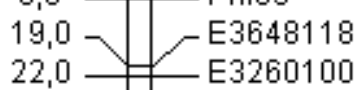

$39,0-\sqrt{\mathrm{E} 4462731}$

54,0 E3359132

$57,0-1-E 3261229$

$59,0-7$ - E4062114

$67,0-\triangle-E 3260176$

67,0 $\mathrm{B}$ - E4062121

77,0 / $/$ E395972

$81,0] /$ Phi27 $^{2}$

89,0 - E3359251

$101,0-/ \$ Mact02b

119,0 E4059484

$161,0>$ E444879

$161,0 \bigcirc-\mathrm{E} 4448131$
C 2

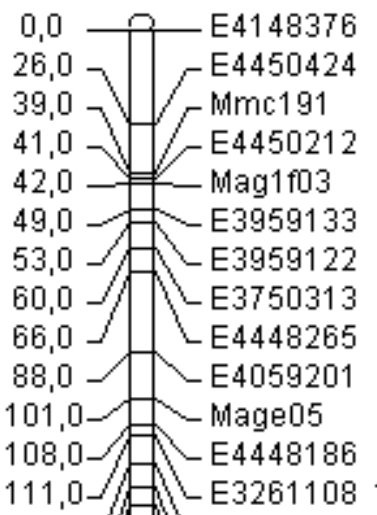

$119,0-$ J E4062271

$125,0 /$ B E406280

130,0-/ LE445099

145,0- LE395989

$153,0 / /$ Ln125

$172,0-$ E3261563

$202,0 \longrightarrow E 4161 b$

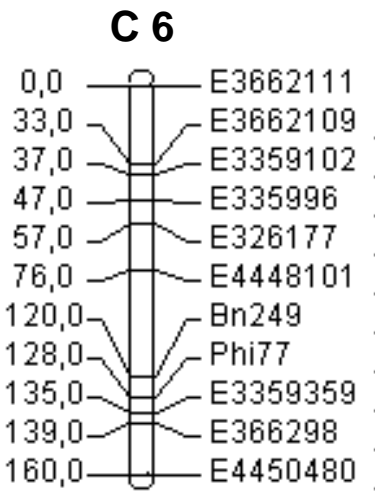

C 10

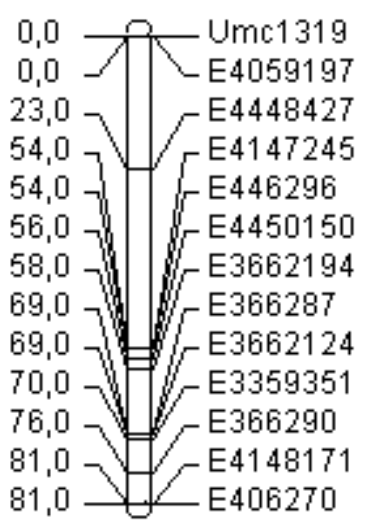

C 3

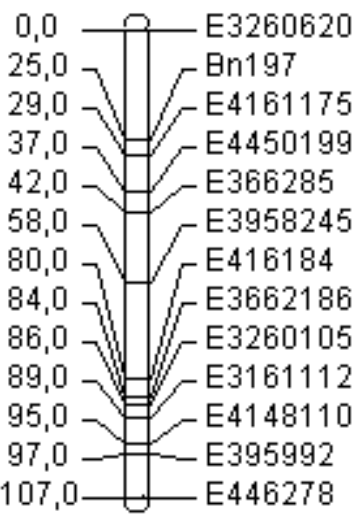

C 7

0,0
36,07
47,04462103 $\left.\begin{array}{l}36,0 \\ 47,0 \\ 52,0\end{array}\right],\left[\begin{array}{l}\mathrm{E} 4462102 \\ \mathrm{E}^{\mathrm{E} 339} \\ \mathrm{E} 4148238\end{array}\right.$ 78,0 刜 $/$ E3260831 $85,0 \neg 1$ - E3662630 88,0 ㄱ․ E $E 3662115$ $89,0 \sim 0$ - E3750150 100,0 , Phi34 101,0 W E4148177 $102,0-M)-E 3648134$ 104,0 $=$ E335979 $115,0, r^{E 446286}$ $119,0-\mathrm{l} / \mathrm{C}_{\mathrm{E} 446287}$ $126,0, \sqrt{r^{E 4448335}}$ $133,0-\mathrm{A}=\mathrm{-E} 3161329$ $135,0-1 /$ E326183 $138,0-E 3261126$ $139,0-7-E 3161162$ $149,0-7$ E3750139 $160,0 \_$E416183
C 4

0,0 - E4059131 $31,0 \frown r^{\mathrm{Bn} 1589}$ $48,0 \sqrt{r^{\mathrm{E} 4161450}}$ $54,07 / r^{E 4062438}$ $56,0, \sqrt{-\mathrm{E} 4062162}$ $59,0-E 3750243$ $60,0-2-E 4450120$ $63,0-\longrightarrow$ E4462470 67,0 LE4059151 $82,0 \bigcirc \mathrm{L} 4161463$ $104,0-\mathrm{E} 3161210$ 124,0_-__ E3959179 $138,0-1-E 4148134$ $145,0 \longrightarrow-$ Bn2291 $146,0-$ E4148135 $163,0-7-M t t g b 02$ $200,0 \quad{ }^{E 326093}$ $208,0>r^{\mathrm{E} 4462276}$ $211,0-1-$ E3261196 $216,0-1=$ E4450101 $220,0-2-E 4059390$ $223,0-\mathrm{E} 4450123$ $249,0-\mathrm{E} 3359113$ $256,0 \bigcirc-E 4448107$

\section{8}

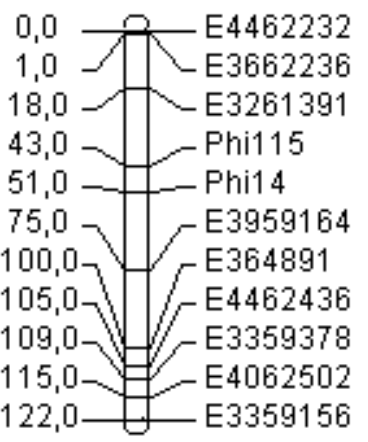

Figura 6 - Mapa genético gerado por marcadores SSR e AFLPS. A direita estão os locos marcadores e a esquerda, as distâncias em cM segundo função de mapeamento de Haldane 
Tabela 12. Resultados da análise de ligação dos marcadores SSR e AFLPs na construção do mapa genético da população $F_{2}$ (Das86 $\times$ Das21). Número de marcas agrupadas, ordenadas, comprimento dos grupos de ligação (cM) e distância média entre marcas (DM)

\begin{tabular}{ccccc}
\hline Cromossomo & Agrupadas & Ordenadas & Comprimento & DM \\
\hline 1 & 14 & 10 & 94,0 & 9,4 \\
2 & 26 & 20 & 202,0 & 10,1 \\
3 & 19 & 13 & 107,0 & 8,2 \\
4 & 34 & 24 & 256,0 & 10,7 \\
5 & 27 & 18 & 139,0 & 7,7 \\
6 & 12 & 11 & 160,0 & 14,5 \\
7 & 25 & 21 & 160,0 & 7,6 \\
8 & 12 & 11 & 122,0 & 11,1 \\
9 & 19 & 16 & 161,0 & 10,1 \\
10 & 24 & 13 & 81,0 & 6,2 \\
Não Agrup. & 23 & - & - & - \\
\hline Total & 212 & $157(74,1 \%)$ & 1482,0 & 9,4 \\
\hline
\end{tabular}

\subsubsection{Associação de marcadores moleculares a QRLs pela análise de regressão linear múltipla}

Inicialmente, devido ao grande número de marcadores analisados neste estudo, realizou-se uma análise de regressão linear simples entre marcador e as médias ajustadas de severidade da doença (comprimento de lesão) das famílias $\mathrm{F}_{2: 3}$ de cada ensaio, com o intuito de pré-selecionar marcas associadas a QRLs de resistência e então utilizá-las para a construção de modelos de regressão linear múltipla. 
$\mathrm{Na}$ genotipagem da população $F_{2}$, locos microssatélites foram codificados utilizando-se -1 para representar indivíduos homozigotos para o alelo marcador do genitor suscetível (Das86), 0 para indivíduos heterozigotos e 1 para homozigotos para o alelo do genitor resistente (Das21). Desta forma, a origem parental do alelo de resistência no QRL foi determinada pelo sinal do coeficiente de regressão: se negativo (decréscimo no comprimento de lesão), infere-se que o alelo de resistência descende do genitor resistente e, se positivo (acréscimo no comprimento de lesão), descende do genitor suscetível. Por outro lado, marcadores AFLPs foram codificados com 1 para presença e 0 para ausência do fragmento amplificado no indivíduo. Se o coeficiente de regressão apresentar sinal negativo, indica que a presença do marcador AFLP está associado com a redução do comprimento de lesão (marcador em associação com o alelo de resistência no QRL), se positivo, aumento da doença (marcador em repulsão com o alelo de resistência no QRL). Nestes casos, a origem parental do alelo marcador AFLP foi realizada através da leitura dos géis.

No primeiro ensaio foram identificados 9 marcadores associados a QRLs a C. graminicola (Tabela 14). Destes, três oriundos do genitor resistente apresentaram forte associação a alelos de resistência no QRL, com efeitos fenotípicos variando de $2,1 \%$ a $10,81 \%$. Os demais marcadores foram associados a alelos de suscetibilidade no QRL, oriundos tanto do genitor resistente (Das21) quanto do genitor suscetível (Das86). 
Tabela 14. Resumo da análise de regressão múltipla entre marcadores AFLPs e microssatélites para o comprimento de lesão de C. graminicola, utilizando o procedimento "Stepwise" no ensaio 1

\begin{tabular}{lccccccc}
\hline Marcadores & $\begin{array}{c}\text { Estimativa } \\
\text { Parâmetros }\end{array}$ & $\begin{array}{c}\text { Erro } \\
\text { Padrão }\end{array}$ & $F^{*}$ & $\begin{array}{c}\mathrm{R}^{2} \\
\text { Parcial }\end{array}$ & $\begin{array}{c}\mathrm{C}^{1} \\
\text { Origem } \\
\text { AFLP }\end{array}$ & $\begin{array}{c}\text { Origem } \\
\text { alelo R }\end{array}$ \\
\hline E4462227 & $-2,9104$ & 0,8184 & 12,65 & 0,1081 & NA & PR & PR \\
E4161A & 2,6273 & 0,8617 & 9,30 & 0,0754 & NA & PS & PR \\
E4462186 & $-2,9605$ & 0,8863 & 11,16 & 0,0671 & NA & PR & PR \\
E4147503 & 3,3051 & 0,8918 & 13,73 & 0,0483 & NA & PR & PS \\
E3662186 & 3,5790 & 1,2499 & 8,20 & 0,0386 & 3 & PR & PS \\
E4059315 & 3,3293 & 1,0374 & 10,30 & 0,0335 & 7 & PS & PR \\
E3359195 & 2,4841 & 0,8262 & 9,04 & 0,0325 & 2 & PR & PS \\
E3662112 & 2,9957 & 1,0703 & 7,83 & 0,0218 & NA & PS & PR \\
Phi77 & $-1,7096$ & 0,5858 & 8,52 & 0,0210 & 6 & - & PR \\
& & $R^{2}$ do modelo =0,4463 & & \\
\end{tabular}

* significativo a $\mathrm{P}<0,05 . \mathrm{C}^{1}=$ cromossomo. NA marcador não agrupado

No segundo ensaio, quatro marcadores AFLPs apresentaram forte associação a alelos de resistência no QRL sendo dois (E4462470 e E3359161) oriundos do genitor resistente e dois (E4161103 e E3959272) do genitor suscetível. Por outro lado, alelos responsáveis pela suscetibilidade também foram localizados no genitor resistente Das21, nos cromossomos 4 e 1, respectivamente (Tabela 15). 
Tabela 15. Resumo da análise de regressão múltipla entre marcadores AFLPs e microssatélites para o comprimento de lesão de C. graminicola, utilizando o procedimento "Stepwise" no ensaio 2

\begin{tabular}{lccccccc}
\hline Marcadores & $\begin{array}{c}\text { Estimativa } \\
\text { Parâmetros }\end{array}$ & $\begin{array}{c}\text { Erro } \\
\text { Padrão }\end{array}$ & $F^{*}$ & $\begin{array}{c}\mathrm{R}^{2} \\
\text { Parcial }\end{array}$ & $\begin{array}{c}\mathrm{C}^{1} \\
\text { Origem } \\
\text { AFLP }\end{array}$ & $\begin{array}{c}\text { Origem } \\
\text { alelo R }\end{array}$ \\
\hline E4462470 & $-21,8560$ & 4,2944 & 25,90 & 0,1475 & 4 & PR & PR \\
E4161103 & $-16,8779$ & 3,4359 & 24,13 & 0,1207 & 1 & PS & PS \\
E3959272 & $-12,2902$ & 2,9021 & 17,93 & 0,0569 & 5 & PS & PS \\
E3662630 & 9,8819 & 2,8072 & 12,39 & 0,0550 & 7 & PS & PR \\
E3359161 & $-10,2368$ & 3,0130 & 11,54 & 0,0407 & NA & PR & PR \\
E4161463 & 11,5655 & 4,2243 & 7,50 & 0,0412 & 4 & PR & PS \\
E4148105 & 7,9309 & 2,9671 & 7,14 & 0,0326 & 1 & PR & PS \\
E4148171 & 6,4599 & 2,6381 & 6,00 & 0,0247 & 10 & PS & PR \\
E3359132 & 10,6468 & 3,0499 & 12,19 & 0,0185 & 9 & PS & PR \\
& & $R^{2}$ do modelo =0,5378 & & \\
\end{tabular}

* significativo a $P<0,05 . C^{1}=$ cromossomo. NA marcador não agrupado

As análises de regressão dos resultados do último ensaio revelaram sete marcadores associados a genes de resistência. Destes, 4 marcadores AFLPs apresentaram associação com alelos de resistência. Os marcadores E4062121 e E446286, localizados nos cromossomos 9 e 7, respectivamente, estão associados a alelos de resistência oriundos do genitor resistente, ao passo que os marcadores E3958127 e E4462436 estão associados a alelos de resistência oriundos do genitor suscetível (Tabela 16). 
Tabela 16. Resumo da análise de regressão múltipla entre marcadores AFLPs e microssatélites para o comprimento de lesão de C. graminicola, utilizando o procedimento "Stepwise" no ensaio 3

\begin{tabular}{|c|c|c|c|c|c|c|c|}
\hline Marcadores & $\begin{array}{l}\text { Estimativa } \\
\text { Parâmetros }\end{array}$ & $\begin{array}{c}\text { Erro } \\
\text { Padrão }\end{array}$ & $F^{*}$ & $\begin{array}{c}\mathrm{R}^{2} \\
\text { Parcial }\end{array}$ & $C^{1}$ & $\begin{array}{l}\text { Origem } \\
\text { AFLP }\end{array}$ & $\begin{array}{l}\text { Origem } \\
\text { alelo } \mathrm{R}\end{array}$ \\
\hline E4062121 & $-3,6783$ & 1,1834 & 9,66 & 0,0900 & 9 & PR & PR \\
\hline E446286 & $-3,5737$ & 1,1437 & 9,76 & 0,0600 & 7 & PR & PR \\
\hline E3958127 & $-3,3326$ & 1,0889 & 9,37 & 0,0536 & NA & PS & PS \\
\hline E3958456 & 4,1297 & 1,3860 & 8,88 & 0,0459 & NA & PS & PR \\
\hline E3260957 & 3,8067 & 1,2577 & 9,16 & 0,0528 & 5 & PR & PS \\
\hline E4462436 & $-2,4197$ & 1,1290 & 4,59 & 0,0359 & 8 & PS & PS \\
\hline Bnlg249 & 1,4224 & 0,7096 & 4,02 & 0,0274 & 6 & - & PR \\
\hline \multicolumn{8}{|c|}{$\mathrm{R}^{2}$ do modelo $=0,3656$} \\
\hline
\end{tabular}

* significativo a $\mathrm{P}<0,05 . \mathrm{C}^{1}=$ cromossomo. NA marcador não agrupado

A análise combinada dos ensaios revelou 13 marcadores ligados a QRLs. Destes, 5 (E4462470, E4161103, E3662630, E3959272 e E4148105) também foram detectados na análise do segundo ensaio e 5 estão ligados a alelos de resistência. Os demais marcadores AFLPs foram associados a alelos de suscetibilidade provenientes tanto do genitor resistente como do suscetível (Tabela 17). 
Tabela 17. Resumo da análise de regressão múltipla entre marcadores AFLPs e microssatélites para o comprimento de lesão de C. graminicola, utilizando o procedimento "Stepwise" na análise conjunta

\begin{tabular}{lccccccc}
\hline Marcadores & $\begin{array}{c}\text { Estimativa } \\
\text { Parâmetros }\end{array}$ & $\begin{array}{c}\text { Erro } \\
\text { Padrão }\end{array}$ & $\mathrm{F}^{*}$ & $\begin{array}{c}\mathrm{R}^{2} \\
\text { Parcial }\end{array}$ & $\mathrm{C}^{1}$ & $\begin{array}{c}\text { Origem } \\
\text { AFLP }\end{array}$ & $\begin{array}{c}\text { Origem } \\
\text { alelo R }\end{array}$ \\
\hline E4462470 & $-3,4526$ & 1,1831 & 8,52 & 0,1432 & 4 & PR & PR \\
Phi65 & $-2,3799$ & 0,7185 & 10,97 & 0,0905 & 9 & - & PR \\
E4161103 & $-7,7516$ & 1,4351 & 29,18 & 0,0782 & 1 & PS & PS \\
E3662630 & 4,8709 & 1,2342 & 15,58 & 0,0695 & 7 & PS & PR \\
E3959272 & $-3,6931$ & 1,2376 & 8,91 & 0,0689 & 5 & PS & PS \\
E4462173 & $-3,9962$ & 1,2410 & 10,37 & 0,0361 & NA & PS & PS \\
E4148105 & 2,7665 & 1,2897 & 4,60 & 0,0280 & 1 & PR & PS \\
E3662194 & 3,6121 & 1,2538 & 8,30 & 0,0223 & 10 & PS & PR \\
E366285 & 3,4175 & 1,3667 & 6,25 & 0,0204 & 3 & PR & PS \\
E445099 & 2,6809 & 1,1434 & 5,50 & 0,0178 & 2 & PR & PS \\
E3662112 & 4,1041 & 1,4324 & 8,21 & 0,0239 & NA & PS & PR \\
E3750238 & 3,2647 & 1,2150 & 7,22 & 0,0188 & 4 & PS & PR \\
E3260105 & 3,6969 & 1,5426 & 5,74 & 0,0167 & 3 & PR & PS \\
& & $R^{2}$ do modelo $=0,6343$ & & & \\
\hline
\end{tabular}

* significativo a $\mathrm{P}<0,05 . \mathrm{C}^{1}=$ cromossomo. NA marcador não agrupado

A proporção da variação fenotípica explicada pela associação entre marcadores e genes de resistência foi obtida pelo coeficiente de determinação $\mathrm{R}^{2}$ e a proporção da variação fenotípica explicada pelos marcadores moleculares individualmente pelo $\mathrm{R}^{2}$ parcial. Os modelos obtidos pela análise de regressão múltipla explicaram de 44\% (primeiro ensaio) a 63\% (análise conjunta) da variação em resistência/suscetibilidade à antracnose do colmo, valores próximos aos obtidos em outros estudos de resistência quantitativa a patógenos em milho, incluindo Cercospora zeae-maydis (Bubeck et al., 1993; 
Saghai Marooff et al., 1996), Exserohilum turcicum (Freymark et al., 1994), Gibberella zeae (Pè et al., 1993), Peronosclerospora maydis (George et al., 2003), Puccinia sorghi (Lübberstedt et al., 1998; Kerns et al., 1999), Puccinia polysora (Holland et al., 1998) e Vírus do mosaico da cana (Yuan et al., 2003).

Dentre as análises individuais, o modelo de regressão múltipla para o segundo ensaio explicou a maior magnitude da variação para resistência a $C$. graminicola. Este fato pode ser atribuído às condições ambientais mais propícias ao desenvolvimento da doença, o que possibilitou uma melhor discriminação entre famílias resistentes e suscetíveis. De maneira geral, foram encontradas associações significativas entre marcadores e genes de resistência/suscetibilidade a C. graminicola nos 10 cromossomos de milho, mas a significância de tais associações foram dependentes do ensaio analisado (Tabela 18). Tomando-se por base os resultados das análises individuais e conjunta, foram identificados sete marcadores ligados a alelos de resistência a C. graminicola em regiões cromossômicas distintas, as quais apresentaram coeficientes de regressão parcial variando de 2,1\% (cromossomo 6.01) até 14,7\% (cromossomo 4.10). Entretanto, mais 5 marcadores AFLPs não ligados também foram significativos (Tabela 18). Dos 11 marcadores AFLPs responsáveis pela redução no comprimento de lesão, seis foram oriundos do genitor resistente e cinco do suscetível. Da mesma forma, dos 10 marcadores AFLPs responsáveis pelo aumento da doença, seis deles são oriundos do genitor resistente e quatro do suscetível (Tabela 18). 
Tabela 18. Cromossomo/bin, loco marcador e efeito estimado dos alelos associados com resistência à antracnose de colmo (C. graminicola) baseados na análise de regressão linear múltipla

\begin{tabular}{|c|c|c|c|c|c|}
\hline \multirow[b]{2}{*}{ Cromossomo/bin } & \multirow[b]{2}{*}{ Marcador } & \multicolumn{4}{|c|}{ Efeito $\left(\mathrm{R}^{2}\right.$ parcial) } \\
\hline & & Ensaio 1 & Ensaio 2 & Ensaio 3 & Conjunta \\
\hline 1.02 & E4161103 & & $-12,1$ ** & & $-7,8$ ** \\
\hline $1 \mathrm{NO}$ & E4148105 & & 3,26 ** & & 2,80 ** \\
\hline $2 \mathrm{NO}$ & E3359195 & $3,25^{\star \star}$ & & & \\
\hline 3.08 & E3662186 & 3,86 ** & & & \\
\hline 4,07 & E4161463 & & 4,12 ** & & \\
\hline 4.10 & E4462470 & & $-14,7^{\star *}$ & & $-14,3^{\star \star}$ \\
\hline 5.05 & E3959272 & & $-5,7 * *$ & & $-6,9 * *$ \\
\hline 5.05 & E3260957 & & & 5,28 ** & \\
\hline 6.01 & Phi77 & $-2,1$ ** & & & \\
\hline 6.01 & Bnlg249 & & & 2,74 ** & \\
\hline $7 \mathrm{NO}$ & E4059315 & 3,35 ** & & & \\
\hline 7.02 & E446286 & & & $-6,00 * *$ & \\
\hline 7.02 & E3662630 & & $5,5 * *$ & & 6,95 ** \\
\hline 8.04 & E4462436 & & & $-3,6$ ** & \\
\hline 9.03 & E4062121 & & & $-9,00 * *$ & \\
\hline 9.03 & Phi65 & & & & $-9,00 * *$ \\
\hline 10.07 & E4148171 & & 2,47 ** & & \\
\hline NA & E4462227 & $-10,80 * *$ & & & \\
\hline NA & E4462186 & $-6,70 * *$ & & & \\
\hline NA & E3359161 & & $-4,10 * *$ & & \\
\hline NA & E3958127 & & & $-5,40 * *$ & \\
\hline NA & E4462173 & & & & $-3,60 * *$ \\
\hline NA & E4161A & 7,54 ** & & & \\
\hline NA & E4147503 & 4,83 ** & & & \\
\hline
\end{tabular}

** significativo a $\mathrm{P}<0,01$

sinal - alelo associado a redução do comprimento de lesão

NO loco marcador agrupado mas não ordenado no cromossomo

NA loco marcador não agrupado em cromossomo 
O mapeamento de alelos de suscetibilidade no genitor resistente, em todos os ensaios, reforça a hipótese de que a alta suscetibilidade encontrada na maioria das famílias $F_{2: 3}$ e na geração $F_{1}$, resulta da combinação de alelos de suscetibilidade da linhagem resistente Das21 com os da linhagem suscetível Das86, corroborando com os resultados observados no capítulo 1. Este fato, pode ser comprovado pela análise da constituição genotípica de cinco famílias $\mathrm{F}_{2: 3}$ extremas em resistência e suscetibilidade nos locos marcadores AFLPs associados a resistência/suscetibilidade (Tabela 19). A freqüência de alelos de resistência nas cinco famílias mais suscetíveis foi de 0,33 contra 0,80 na cinco famílias mais resistentes. Vale destacar que a família 143 apresentou alelos favoráveis em todos os QRLs, consistindo portanto em interessante fonte de resistência a ser usada em programas de melhoramento (Tabela 19).

Uma provável explicação da distribuição igualitária dos alelos de resistência/suscetibilidade entre os genitores pode ser devido ao agrupamento destes alelos em "clusters" gênicos. A manutenção de alelos de suscetibilidade à antracnose do colmo nos genitores, pode estar relacionada ao fato destes alelos possivelmente pertencerem a rotas metabólicas importantes para a manutenção da planta ou, ainda, por estarem associados a regiões genômicas responsáveis por outras características fenotípicas de interesse agronômico.

$\mathrm{O}$ único gene de resistência à antracnose do colmo mapeado até o momento foi o relatado por Jung et al. (1994), que explicou 73\% da variação fenotípica para resistência e está localizado no cromossomo 4 (bin 08). No presente estudo, um QRL de efeito maior (14,7\% da variação fenotípica no segundo ensaio e $14,3 \%$ da análise conjunta) também foi localizado no mesmo cromossomo, porém no bin 10. Dessa maneira é provável que estes QRLs sejam os mesmos e sendo assim as diferenças observadas no efeito fenotípico do QRL e na sua posição no cromossomo podem ser explicadas pelo maior número de indivíduos genotipados na população de mapeamento do referido trabalho. No entanto, a hipótese de se tratarem de QRLs distintos não pode ser 
descartada, uma vez que as populações utilizadas descendem de linhagens de constituição genética distinta.

Tabela 19. Constituição genotípica de uma amostra de cinco famílias $F_{2: 3}$ extremas para resistência/suscetibilidade a $C$. graminicola (análise conjunta), para os alelos AFLPs associados com a redução ou incremento do comprimento de lesão para o genitor resistente e suscetível

\begin{tabular}{cccccccc}
\hline & & \multicolumn{2}{c}{ PR (-) } & \multicolumn{2}{c}{ PS (-) } & PR (+) & PS (+) \\
\cline { 3 - 8 } Famílias & Comp & E4462227 & E4062121 & E3959272 & E3958127 & E3260957 & E4161A \\
\hline Suscetível & & & & & & & \\
224 & 60,8 & $\mathrm{R}$ & $\mathrm{R}$ & $\mathrm{S}$ & $\mathrm{S}$ & $\mathrm{S}$ & $\mathrm{S}$ \\
209 & 50,4 & $\mathrm{~S}$ & $\mathrm{R}$ & $\mathrm{R}$ & $\mathrm{R}$ & $\mathrm{S}$ & $\mathrm{S}$ \\
65 & 53,8 & $\mathrm{~S}$ & $\mathrm{~S}$ & $\mathrm{R}$ & $\mathrm{S}$ & $\mathrm{S}$ & $\mathrm{S}$ \\
178 & 51,7 & $\mathrm{R}$ & $\mathrm{S}$ & $\mathrm{R}$ & $\mathrm{R}$ & $\mathrm{S}$ & $\mathrm{S}$ \\
199 & 50,9 & $\mathrm{~S}$ & $\mathrm{~S}$ & $\mathrm{~S}$ & $\mathrm{R}$ & $\mathrm{S}$ & $\mathrm{S}$ \\
Resistente & & & & & & & \\
28 & 21,3 & $\mathrm{R}$ & $\mathrm{R}$ & $\mathrm{R}$ & $\mathrm{R}$ & $\mathrm{S}$ & $\mathrm{S}$ \\
64 & 21,1 & $\mathrm{R}$ & $\mathrm{R}$ & $\mathrm{R}$ & $\mathrm{R}$ & $\mathrm{S}$ & $\mathrm{R}$ \\
143 & 21,0 & $\mathrm{R}$ & $\mathrm{R}$ & $\mathrm{R}$ & $\mathrm{R}$ & $\mathrm{R}$ & $\mathrm{R}$ \\
141 & 21,0 & $\mathrm{R}$ & $\mathrm{R}$ & $\mathrm{R}$ & $\mathrm{R}$ & $\mathrm{S}$ & $\mathrm{S}$ \\
49 & 20,4 & $\mathrm{R}$ & $\mathrm{R}$ & $\mathrm{R}$ & $\mathrm{R}$ & $\mathrm{S}$ & $\mathrm{R}$ \\
\hline
\end{tabular}

- e +, indicam redução e incremento no comprimento de lesão

$\mathrm{R}$ e $\mathrm{S}$, indicam alelo de resistência e alelo de suscetibilidade 
Carson \& Hooker (1982) obtiveram indícios da presença de genes de resistência a podridão do colmo nos braços longos dos cromossomos 1, 4, 8 e nos dois braços do cromossomo 6. De fato, no presente estudo, as regiões cromossômicas 1.02, 4.10, 6.01 e 8.04 mostraram associações significativas com genes de resistência. Além destas regiões, QRLs foram mapeados nos cromossomos 7.02 e 9.03. Pè et al. (1993) relataram QRLs para podridão de colmo causada por Gibberella zeae nos cromossomos 1.07, 3.06, 4.01, 5.04 e 10.05, com efeitos fenotípicos variando de 4,1\% a 9,2\% da variação em resistência. Ming et al. (1995), por sua vez, relataram QRLs a Erwinia stewartii nos cromossomos 1, 2, 4, 5, 6, 7, 8 e 9. Da mesma forma, no presente trabalho, QRLs a C. graminicola foram identificados nestes mesmos grupos de ligação, sugerindo que os genes de resistência a estes patógenos podem ser os mesmos. Esta hipótese é reforçada pelo fato de que os três patógenos (Gibberella zeae, Erwinia stewartii e Colletotrichum graminicola) apresentarem os mesmos mecanismos de penetração e colonização dos colmos.

A análise de mapeamento de QRLs a C. graminicola possibilitou a identificação de vários marcadores associados a alelos de resistência entre os três experimentos. Entretanto, os QRLs localizados foram específicos ao ambiente em estudo, sugerindo elevado efeito da interação $Q R L \times$ ambiente para este patossistema (Tabela 19). A ausência de QRLs estáveis ao longo dos ambientes é um indicativo que as populações devem ser avaliadas em vários ambientes afim de obter progresso com a seleção. Além disto, esforços deveriam ser feitos com o intuito de selecionar genótipos com adaptação específica aos ambientes de maior incidência do patógeno como em áreas de semeadura direta e condições climáticas favoráveis para a manifestação da doença. A falta de critérios na seleção de genótipos resistentes a este patógeno, aliada ao elevado crescimento em área cultivada poderão ocasionar surtos epidêmicos.

Finalmente, a localização de QRLs em milho para C. graminicola por meio de marcadores pode facilitar o processo de seleção, conferindo maior 
eficiência aos programas de melhoramento na seleção de grande número de linhagens normalmente disponíveis nas estações experimentais e, conseqüentemente, incrementar os ganhos genéticos na seleção artificial em função da redução dos efeitos ambientais inerentes a este patossistema (Jung et al., 1994).

\subsection{Conclusões}

1. Os métodos de inoculação e avaliação da doença permitiram discriminar níveis de resistência/suscetibilidade à antracnose do colmo entre as famílias $\mathrm{F}_{2: 3}$ do cruzamento Das86 x Das21.

2. Os indivíduos da geração $F_{1}$ foram altamente suscetíveis em todos os experimentos, confirmando efeito acentuado de dominância para suscetibilidade neste cruzamento conforme sugerido na análise de médias de gerações.

3. A estratégia de utilizar locos microssatélites como "âncoras" nos grupos de ligação permitiu que os marcadores AFLPs, sem referência cromossômica prévia, pudessem ser mapeados nos respectivos cromossomos do milho.

4. Dos quatro modelos analisados, 9 marcadores foram identificados associados a QRLs no primeiro ensaio, 9 no segundo, 7 no terceiro e 13 na análise combinada dos experimentos. Foram identificados sete marcadores ligados a alelos de resistência nestes QRLs com coeficientes de regressão parciais variando de $2,1 \%$ a $14,7 \%$. 
5. A proporção da variação fenotípica em resistência devida a associação de QRLs com marcadores para os três ensaios e análise conjunta, variou de $44 \%$ a $63 \%$.

6. As associações entre marcadores e QRLs foram dependentes do experimento analisado, indicando uma forte interação $Q R L x$ ambiente neste patossistema.

7. Foram localizados alelos de resistência no genitor suscetível bem como alelos de suscetibilidade no genitor resistente. A elevada suscetibilidade das famílias $F_{2: 3}$ parece advir da combinação de alelos de suscetibilidade oriundos do genitor resistente com aqueles do genitor suscetível ou vice-versa no caso das famílias mais resistentes.

8. Neste patossistema a seleção assistida por marcadores moleculares facilitará a identificação de progênies resistentes pelos programas de melhoramento por minimizar a influência das condições ambientais na expressão da resistência. 


\section{ESTIMATIVAS DE DANOS EM MILHO TROPICAL OCASIONADOS PELA ANTRACNOSE DE COLMO}

\section{Resumo}

A incidência de Colletotrichum graminicola como agente causal de podridão de colmo aumentou significativamente nos últimos anos no Brasil devido ao incremento da área cultivada de milho aliado a mudanças nas práticas culturais, como a semeadura direta e plantio tardio. Os objetivos deste trabalho foram estimar os danos na produção de grãos ocasionados por este fungo em função do estádio de desenvolvimento da cultura quando da inoculação. Dois ensaios foram conduzidos sob delineamento experimental de blocos casualizados com tratamentos dispostos em esquema fatorial 2 (híbridos) x 5 (épocas de inoculação e testemunhas) com três repetições. Os tratamentos consistiram da combinação dos fatores híbridos, suscetível e resistente, e três épocas de inoculação (20, 40, 60 dias após a emergência) além de duas testemunhas com e sem inoculação com água. As plantas foram inoculadas com solução de esporos na concentração $1,8 \times 10^{5}$ conídios $/ \mathrm{mL}$. Aos 120 dias após a emergência, avaliou-se o comprimento de lesão (cm), a produção da parcela ajustada (t/ha) e componentes da produção (comprimento, diâmetro e peso de espiga). Além destas características, foi avaliado o número de plantas ao final do ciclo reprodutivo/parcela. Os híbridos diferiram significativamente entre si com relação a todas as características avaliadas. No entanto, diferenças significativas na produção e peso de espiga ocorreram apenas para o híbrido suscetível quando inoculado aos 20 dias após a 
emergência. Neste caso, as reduções em produção foram de 16,1 e 20,2\% para cada ensaio. Não foram verificadas diferenças significativas em comprimento de lesão em ambos os híbridos em função da data de inoculação. Conclui-se, portanto, que as perdas advindas da infecção no início do plantio não são devidas a maior severidade de ataque do patógeno. A redução na produção do híbrido suscetível H8621, inoculado ao 20DAE com C. graminicola, também pode ser atribuída a maior mortandade de plantas neste tratamento.

\section{Yield losses caused by anthracnose stalk rot in tropical maize}

\section{Summary}

The incidence of Colletotrichum graminicola as the causal agent of stalk rot has increased significantly in recent years in Brazil due to an increase in the area cultivated with maize, in addition to changes in cultural practices, such as direct (no-tillage) and late planting. The objectives of this work were to estimate grain yield reduction caused by this fungus as a function of the crop's growth stage at the time of inoculation. Two trials were conducted under a randomized blocks experimental design with treatments arranged as a $2 \times 5$ factorial scheme with three replicates. Treatments consisted of the combination of hybrids, susceptible and resistant, and three inoculation dates $(20,40,60$ days after emergence), plus two controls, with and without water inoculation. Plants were inoculated with a spore suspension at the concentration of $1.8 \times 10^{5}$ conidia/mL. At 120 days after emergence evaluations were made for lesion length, adjusted yield (ton/ha), and yield components (ear length, diameter and weight). The hybrids differed significantly from each other with regard to lesion length. However, significant differences in yield/plot and ear weight occurred only for the susceptible hybrid when inoculated at 20 days after emergence. In 
this case, the yield reductions were 16.1 and $20.2 \%$ for each trial. No significant differences were observed for lesion length in any of the two hybrids as a function of inoculation date. It can therefore be concluded that losses caused by infection at the beginning of planting are not due to a greater severity of attack by the pathogen.

\subsection{Introdução}

Vários fitopatógenos podem ocasionar podridão do colmo em milho tais como Gibberella zeae, Colletotrichum graminicola, Stenocarpella maydis, Bipolaris zeicola e alguns membros do gênero Fusarium (Gatch \& Munkvold, 2002). Destas espécies, C. graminicola (Ces.) Wils destaca-se como uma das mais importantes (Gilbertson et al., 1985; Denti \& Reis, 2003).

Sintomas de podridão do colmo causada por C. graminicola, doença também denominada de antracnose do colmo, surgem na epiderme do colmo logo após a polinização, na forma de lesões estreitas, encharcadas, inicialmente de cor parda a avermelhada que tornam-se marrons escuras. A doença apresenta-se mais severa em regiões quentes e úmidas, com extensos períodos nublados. A semeadura direta sobre a palhada de milho, prática agrícola cada vez mais adotada no Brasil, favorece sua ocorrência, uma vez que o patógeno sobrevive em restos culturais (Naylor \& Leonard, 1977). Danos na produção de grãos ocasionados pela podridão do colmo estão relacionados à destruição interna dos tecidos do colmo que podem causar a morte prematura de plântulas ou ainda sua quebra. Neste caso, ocorre perda na qualidade do grão devido à infecção da espiga por fungos em decorrência de seu contato com o solo (Shurtleff, 1980; Jarvis et al., 1984).

Em alguns países como a França, Índia e Filipinas, esta doença é um fator limitante à cultura (Shurtleff, 1980). Nos Estados Unidos, a podridão do colmo despertou interesse somente após severas epidemias ocorridas na safra 
de 1980 que resultaram em perdas de até 28\% (Carson \& Hooker, 1981), embora trabalhos anteriores já tivessem chamado a atenção para o aumento da incidência e para o potencial destrutivo da doença (Williams \& Willis, 1963; Leonard \& Thompson, 1969; Poneleit et al., 1972).

Estudos relativos a estimativas de danos ocasionados por $C$. graminicola baseiam-se em ocorrência natural da doença e talvez por isto sejam escassos e discrepantes. De fato, White et al. (1979) relataram que as estimativas de reduções no rendimento de grãos foram altamente dependentes do ambiente e do genótipo estudado. Perkins \& Hooker (1979), por exemplo, observaram desde acréscimos de $11 \%$ até decréscimos de $17 \%$ na produção de grãos em função do material vegetal. Keller et al. (1986) observaram reduções de 8 a 35\% no rendimento de um híbrido suscetível. Finalmente, Dale (1963) e Callaway et al. (1992) não encontraram associação significativa entre redução no rendimento de grãos e infecção por C. graminicola. No Brasil, o primeiro relato de ocorrência do patógeno registrou redução de 30\% na produção (Silveira et al., 1965). No estado do Paraná, estes variaram de 12 a $40 \%$, dependendo do ano, local e híbrido utilizado (Nazareno, 1989). Denti \& Reis (2003) relataram nível de incidência médio de 40,9\% e 45,9\% em lavouras amostradas no Planalto Médio Gaúcho e nos Campos Gerais do Paraná de fungos associados ao complexo causador das podridões da base do colmo em duas safras agrícolas. Os danos quantificados variaram em média de $678 \mathrm{~kg} / \mathrm{ha}$ a $1.151 \mathrm{~kg} / \mathrm{ha}$. Entretanto, não foram observadas correlações significativas entre incidência e danos na produção. Das espécies fúngicas amostradas, C. graminicola prevaleceu na primeira safra e Fusarium graminearum na segunda.

A dificuldade em obter informações precisas acerca dos danos ocasionados por podridões de colmos se deve à necessidade de padronizar métodos de inoculação e de avaliação de sintomas. Neste caso, a avaliação é dificultada sobremaneira pelo fato dos sintomas serem internos ao colmo. $O$ objetivo deste trabalho foi estimar os danos potenciais na produção de grãos a 
partir de inoculações artificiais de C. graminicola em diferentes estádios fenológicos em híbridos tropicais de milho.

\subsection{Material e Métodos}

O material vegetal compreendeu dois híbridos (H8664 e H8621) oriundos de germoplasma tropical. O híbrido H8664, resistente a C. graminicola, foi obtido do cruzamento de linhagens originadas de uma população constituída por germoplasma Amarillo Dentado e Flints do Caribe. O híbrido H8621, suscetível, foi obtido do cruzamento de linhagens derivadas desta população com linhagens oriundas de Suwan DMR.

O patógeno foi cultivado em placas de Petri contendo meio de cultura aveia-ágar (40g farinha aveia, $17 \mathrm{~g}$ de ágar e $1000 \mathrm{~mL}$ água) incubados em câmara de crescimento com temperatura e fotoperíodo controlados até a obtenção de colônias esporulantes (aproximadamente 14 dias). O inóculo foi preparado através da adição de $20 \mathrm{~mL}$ de água destilada às placas de Petri seguida de raspagem superficial da cultura com escapelo para liberação dos conídios. A suspensão de esporos foi filtrada através de uma camada dupla de gaze e sua concentração ajustada para 1,8 × 10 conídios $/ \mathrm{mL}$ (Morello, 2000). A cada litro de inóculo foram adicionados 1 gota de Tween 80\%.

Os híbridos foram inoculados com suspensão de esporos em diferentes estádios de desenvolvimento (20, 40 e 60 dias após a emergência; DAE). Estas datas correspondem aproximadamente aos estádios: de 8 folhas, 12 folhas e florescimento pleno. A inoculação foi realizada com $1 \mathrm{~mL}$ da suspensão de esporos no centro do primeiro internódio acima da superfície do solo, com auxílio de uma seringa de uso veterinário. Parcelas sem inoculação e inoculadas com $1 \mathrm{~mL}$ de água estéril aos 20 DAE foram utilizadas como tratamentos testemunha. 
O delineamento experimental consistiu de blocos casualizados com tratamentos dispostos em esquema fatorial 2 (híbridos) x 5 (3 épocas de inoculação e 2 testemunhas) com três repetições. A unidade experimental consistiu de duas linhas de 5,0 m de comprimento com aproximadamente 50 plantas/parcela. O espaçamento entre linhas foi de $0,9 \mathrm{~cm}$. Os ensaios foram implantados em novembro e dezembro de 2002.

Aos 120 dias após a emergência mediu-se a produção da parcela ajustada para tha (13\% de umidade) e o comprimento de lesão $(\mathrm{cm})$ de 5 plantas/parcela. Os componentes da produção (comprimento, diâmetro e peso de espiga) também foram determinados em uma amostra de 5 espigas/tratamento. Além destes, foi avaliado o número de plantas/parcela ao final do ciclo reprodutivo da cultura.

As estimativas de dano para a produção de grãos foram obtidas pela fórmula: Dano (\%) $=\left[\left(X_{\text {Test. Absoluta }}-X_{\text {Trat. Inoc. }}\right) / X_{\text {Test. Absoluta }}\right] * 100$, onde $X_{\text {Test. }}$ Absoluta corresponde à produção média da testemunha absoluta sem inoculação

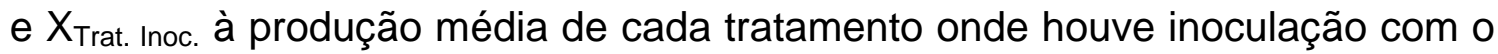
patógeno. Os dados foram submetidos a análise de variância utilizando o programa SAS (SAS Institute, 1993) e as médias dos tratamentos foram comparadas pelo Teste de Tukey a 5\% de probabilidade.

\subsection{Resultados e Discussão}

As análises de variância de cada experimento detectaram diferenças estatísticas entre híbridos para o comprimento de lesão (Tabela 20 e 21), indicando que estes variam em grau de resistência ao patógeno. Os comprimentos de lesão do híbrido H8621 nos tratamentos onde foram realizadas inoculações com $C$. graminicola foram muito superiores aos do híbrido H8664, confirmando a sua elevada suscetibilidade (Tabela 22). Em média, o comprimento de lesão do híbrido suscetível foi aproximadamente 3 
vezes maior que o do híbrido resistente. A resistência observada em H8664 é interessante do ponto de vista de melhoramento, uma vez que o híbrido manteve a produção mesmo quando inoculado com alta concentração de conídios (1,8 x 105 conídios/planta) (Tabela 23).

Tabela 20. Resumo da análise de variância para as variáveis comprimento de lesão $(\mathrm{cm})$, produção $(\mathrm{t} / \mathrm{ha})$, comprimento $(\mathrm{cm})$, diâmetro $(\mathrm{cm})$, peso de espiga (g) e número de plantas/parcela (NP) ao final do ciclo reprodutivo para o primeiro ensaio

\begin{tabular}{lccccccc}
\hline Fonte & G.L. & Lesão & Produção & Comp. & Diâmetro & Peso & NP \\
\hline Bloco & 2 & 8,18 & 0,63 & $3,0 * *$ & 0,01 & 20,9 & 0,23 \\
Híbrido (H) & 1 & 5532 ** & $72,54 * *$ & $27,5 * *$ & $3,1 * *$ & 28768 ** & 2,13 \\
Tratamento (T) & 4 & $3151 * *$ & $1,33 * *$ & 0,95 & 0,02 & 161,1 & 43,67 ** \\
H x T & 4 & $892 * *$ & $0,97 *$ & 0,49 & 0,03 & 184,1 & 32,63 ** \\
Resíduo & 29 & 5,57 & 0,33 & 0,36 & 0,02 & 163,4 & 1,05 \\
Decomposição H x T & & & & & & \\
H8621 & 4 & $3683 * *$ & $2,27 * *$ & - & - & - & $74,73 * *$ \\
H8664 & 4 & $360 * *$ & 0,02 & - & - & - & 1,57 \\
\hline
\end{tabular}

*, **, significativo a $\mathrm{P}<0,05$ e $\mathrm{P}<0,01$, respectivamente 
Tabela 21. Resumo da análise de variância para as variáveis comprimento de lesão $(\mathrm{cm})$, produção $(\mathrm{t} / \mathrm{ha})$, comprimento $(\mathrm{cm})$, diâmetro $(\mathrm{cm})$, peso de espiga (g) e número de plantas/parcela (NP) ao final do ciclo reprodutivo para o segundo ensaio

\begin{tabular}{lccccccc}
\hline Fonte & G.L. & Lesão & Produção & Comp. & Diâmetro & Peso & NP \\
\hline Bloco & 2 & 1,09 & 0,26 & 0,03 & 0,004 & 39,4 & 2,13 \\
Híbrido (H) & 1 & $4585^{* *}$ & $16,99 * *$ & $3,80 * *$ & $4,2 * *$ & 16708 ** & 16,13 ** \\
Tratamento (T) & 4 & $2333^{* *}$ & $2,12 * *$ & 0,50 & 0,02 & $464,5 * *$ & 16,22 ** \\
H x T & 4 & $736 * *$ & $1,48 * *$ & 0,30 & 0,04 & $340,8 * *$ & $19,55 * *$ \\
Resíduo & 29 & 4,17 & 0,17 & 0,20 & 0,01 & 61,5 & 1,02 \\
Decomposição H H T & & & & & & \\
H8621 & 4 & $2842 * *$ & $3,31 * *$ & - & - & $645,9 * *$ & $34,43 * *$ \\
H8664 & 4 & $227 * *$ & 0,28 & - & - & 159,4 & 1,33 \\
\hline$*$
\end{tabular}

*, **, significativo a $\mathrm{P}<0,05$ e $\mathrm{P}<0,01$, respectivamente

Tabela 22. Comprimento de lesão $(\mathrm{cm})$ de $C$. graminicola nos híbridos inoculados aos 20, 40 e 60 dias após a emergência em dois ensaios

\begin{tabular}{lcccc}
\hline & \multicolumn{2}{c}{ Ensaio 1} & \multicolumn{2}{c}{ Ensaio 2 } \\
\cline { 2 - 5 } Tratamentos & $\mathrm{H} 8621$ & $\mathrm{H} 8664$ & $\mathrm{H} 8621$ & $\mathrm{H} 8664$ \\
\hline 20 & $67,1 \mathrm{a}$ & $23,9 \mathrm{a}$ & $58,9 \mathrm{a}$ & $17,2 \mathrm{a}$ \\
40 & $68,3 \mathrm{a}$ & $19,7 \mathrm{a}$ & $56,5 \mathrm{a}$ & $16,9 \mathrm{a}$ \\
60 & $65,8 \mathrm{a}$ & $22,9 \mathrm{a}$ & $59,7 \mathrm{a}$ & $18,3 \mathrm{a}$ \\
Test. $\mathrm{H}_{2} \mathrm{O}$ & $6,5 \mathrm{~b}$ & $5,4 \mathrm{~b}$ & $4,6 \mathrm{~b}$ & $3,6 \mathrm{~b}$ \\
Test. Absoluta & $0 \mathrm{c}$ & $0 \mathrm{c}$ & $0 \mathrm{c}$ & $0 \mathrm{c}$ \\
\hline
\end{tabular}

Médias seguidas de mesma letra na coluna não diferem entre si pelo Teste de Tukey a 5\% 
Tabela 23. Comportamento médio da variável produção de grãos (t/ha) e peso de espiga (g) dos híbridos submetidos a inoculação aos 20, 40 e 60 dias após a emergência nos respectivos ensaios

\begin{tabular}{lcccc|cc}
\hline & \multicolumn{4}{c|}{ Produção (t/ha) } & \multicolumn{2}{c}{ Peso Espiga (g) } \\
\cline { 2 - 7 } Tratamentos & \multicolumn{2}{c}{ Ensaio 1 } & \multicolumn{2}{c}{ Ensaio 2 } & \multicolumn{2}{c}{ Ensaio 2 } \\
& H8621 & H8664 & H8621 & H8664 & H8621 & H8664 \\
\hline Test. Absoluta & $11,2 \mathrm{a}$ & $7,8^{\mathrm{ns}}$ & $10,4 \mathrm{a}$ & $8,7^{\mathrm{ns}}$ & $268 \mathrm{a}$ & $200{ }^{\mathrm{ns}}$ \\
20 & $9,4 \mathrm{~b}$ & 7,7 & $8,3 \mathrm{~b}$ & 8,3 & $228 \mathrm{~b}$ & 199 \\
40 & $11,7 \mathrm{a}$ & 7,9 & $10,9 \mathrm{a}$ & 8,1 & $258 \mathrm{a}$ & 204 \\
60 & $10,2 \mathrm{a}$ & 7,8 & $10,4 \mathrm{a}$ & 8,6 & $254 \mathrm{a}$ & 217 \\
Test. $\mathrm{H}_{2} \mathrm{O}$ & $11,2 \mathrm{a}$ & 7,9 & $10,1 \mathrm{a}$ & 8,0 & $253 \mathrm{a}$ & 204 \\
\hline
\end{tabular}

Médias seguidas de mesma letra na coluna não diferem entre si pelo Teste de Tukey a 5\% ${ }^{\text {ns }}$ não significativo

Houve interação significativa entre híbridos e tratamentos para as variáveis comprimento de lesão e produção em ambos os ensaios e também para peso de espiga no segundo ensaio (Tabela 20 e 21). A decomposição destas interações em função do híbrido indicou que a interação para a variável comprimento de lesão foi significativa para ambos os híbridos. Este fato pode ser atribuído às diferenças verificadas entre os tratamentos em que foram realizados inoculações com o patógeno e os tratamentos testemunha (Tabela 21). Por outro lado, a decomposição da interação para os caracteres produção (ambos ensaios) e peso de espiga (segundo ensaio) evidenciou diferenças significativas entre tratamentos apenas para o híbrido suscetível H8621.

A produção de grãos foi significativamente afetada apenas para o híbrido suscetível H8621 quando este foi inoculado aos 20 dias após a emergência (Tabela 23), indicando que somente infecções no início do ciclo levam a danos significativos. Neste caso, a redução na produção ajustada (t/ha) foi de $16,1 \%$ e $20,2 \%$ para os dois ensaios comparado à testemunha não 
inoculada (Figura 7). Na média dos ensaios estes resultados são similares àqueles relatados por Keller et al. (1986), que verificaram reduções de 35\% e $8,1 \%$ em plantas infectadas por C. graminicola no estádio inicial de desenvolvimento do híbrido Cornell281, nas respectivas épocas de semeadura. O dano estimado para o primeiro ensaio foi muito superior ao encontrado no segundo (8,1\%), fato este atribuído as melhores condições ambientais para o desenvolvimento do patógeno na primeira época de semeadura. No entanto, os autores também relataram perdas de $16 \%$ em plantas infectadas durante 0 estádio de florescimento, fato não observado no presente estudo. Esta discrepância pode ser devida a diferenças na constituição genética da suscetibilidade entre híbridos, pois Cornell281 é conhecido por sua elevada suscetibilidade nos EUA, e também às condições experimentais no qual os experimentos foram analisados.

Neste trabalho, outro aspecto importante é que, para ambos híbridos, o comprimento da lesão foi o mesmo independente da época de inoculação do fungo (Tabela 22). Estes resultados concordam com os relatados para podridão do colmo causada por Fusarium moniliforme (Borges et al., 2001). Assim, os danos ocasionados pela inoculação no início do ciclo no híbrido suscetível não se devem a diferenças em severidade da doença entre as épocas de inoculação. Neste caso, a redução na produção pode resultar da interferência no processo de acúmulo de fotoassimilados no colmo que serão posteriormente translocados para a espiga e para o enchimento de grãos (Magalhães et al., 1995). Como o peso de espigas foi o único componente de produção afetado pela inoculação aos 20 DAE (Tabela 23), supõe-se que tal fato seja resultado direto da diminuição dos fotoassimilados nos colmos. Esta conclusão, no entanto, é apenas tentativa, uma vez que tal efeito foi detectado apenas no segundo ensaio.

Finalmente, um outro fator que também pode afetar a produção em decorrência de infecção no estádio inicial da cultura é a morte de plantas. Parcelas do híbrido suscetível inoculadas aos 20 DAE foram as que 
apresentaram menor número médio de plantas (30 e 33 em cada ensaio) ao final do ciclo em relação à testemunha absoluta (41 e 40 plantas, respectivamente). Parte desta redução do estande das parcelas inoculadas se deveu a mortandade de plantas na parcela como foi observado no campo (Figura 8). No caso do híbrido resistente, não foram verificadas reduções no estande da parcela entre os tratamentos (Tabela 24).

No presente trabalho, os valores podem estar um pouco superestimados, uma vez que o ferimento oriundo da inoculação poderia propiciar a entrada de outros patógenos de colmo e ou prejudicar o desenvolvimento normal da cultura. Além disto, numa condição de infecção natural, a quantidade de propágulos infectivos que entram em contato com a planta e o número de plantas atacadas na lavoura seriam ligeiramente inferiores.

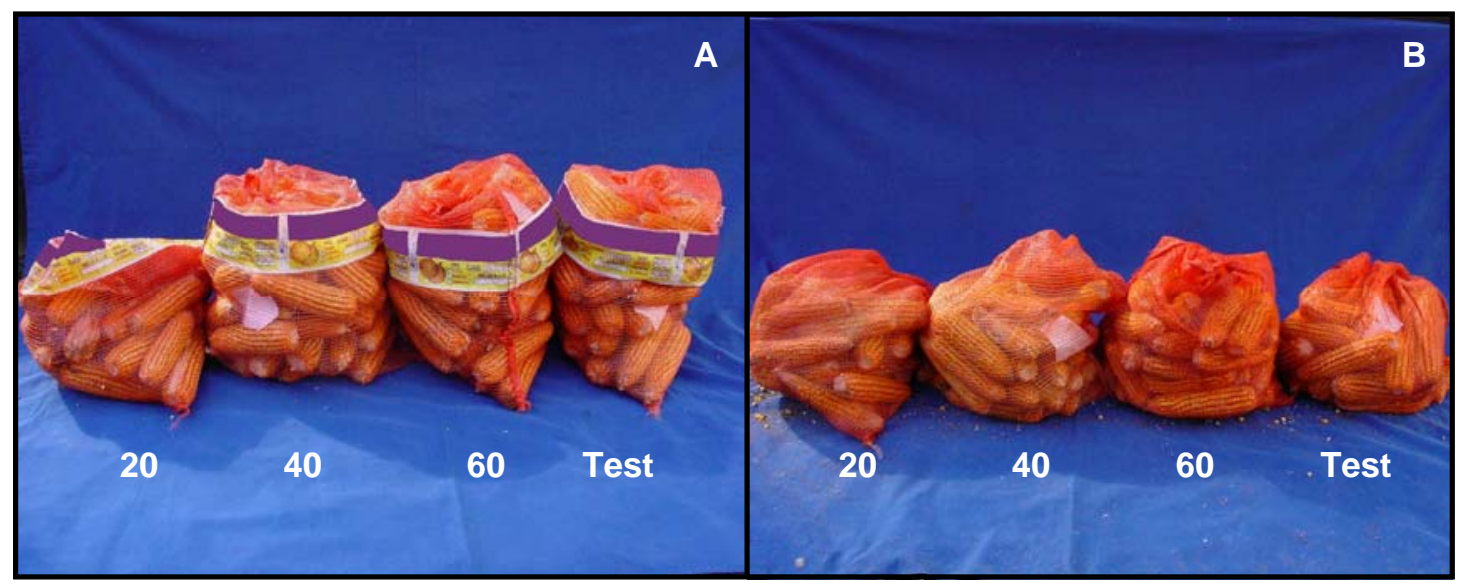

Figura 7 - Produção de grãos de milho em parcelas inoculadas com suspensão de C. graminicola aos 20, 40 e 60 dias após a emergência e sem inoculação (Test). A) Híbrido suscetível - H8621 e B) Híbrido resistente $-\mathrm{H} 8664$ 


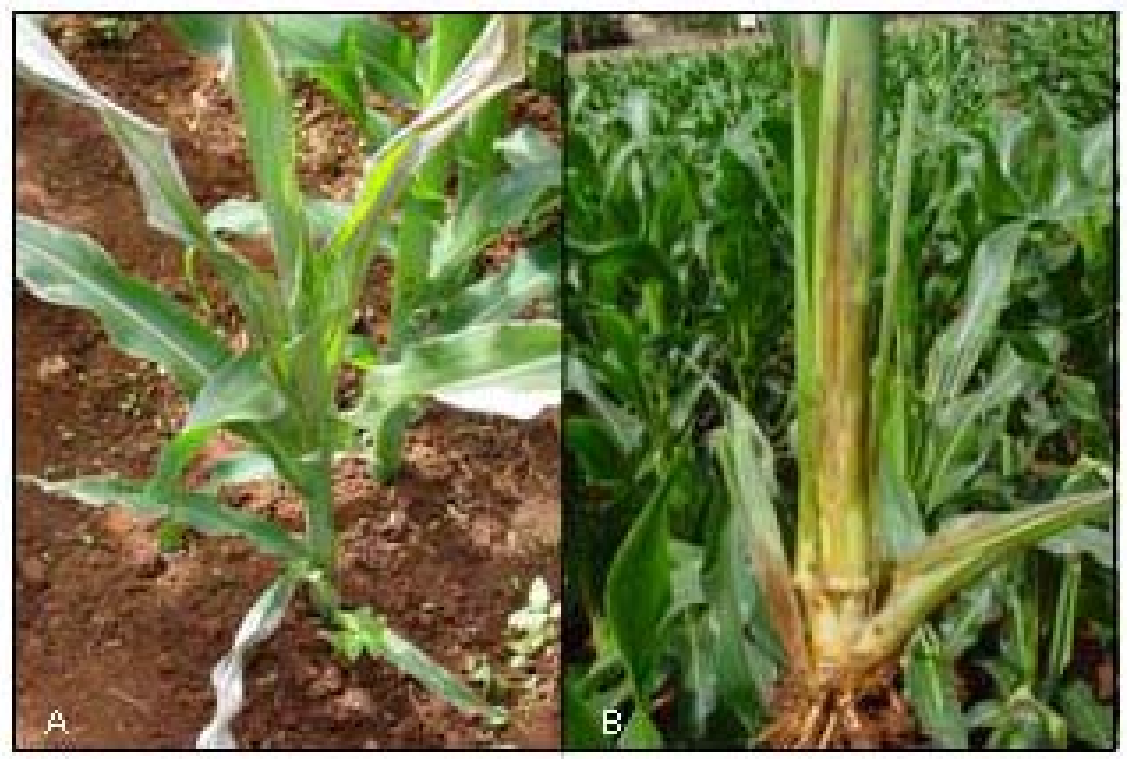

Figura 8 - Aspecto visual da morte de plantas inoculadas aos 20DAE com $C$. gramnicola no híbrido suscetível H8621. A) morte prematura de plantas e B) sintoma típico da antracnose do colmo

Tabela 24. Número de plantas/parcela ao final do ciclo reprodutivo para os dois híbridos submetidos a inoculação aos 20, 40 e 60 dias após a emergência com C. graminicola

\begin{tabular}{lcccc}
\hline & \multicolumn{2}{c}{ Ensaio 1 } & \multicolumn{2}{c}{ Ensaio 2 } \\
\cline { 2 - 5 } Tratamento & $\mathrm{H} 8621$ & $\mathrm{H} 8664$ & $\mathrm{H} 8621$ & $\mathrm{H} 8664$ \\
\hline Test. Absoluta & $41 \mathrm{a}$ & $37^{\mathrm{ns}}$ & $40 \mathrm{a}$ & $36^{\mathrm{ns}}$ \\
20 & $30 \mathrm{~b}$ & 37 & $33 \mathrm{~b}$ & 37 \\
40 & $41 \mathrm{a}$ & 37 & $41 \mathrm{a}$ & 38 \\
60 & $42 \mathrm{a}$ & 39 & $41 \mathrm{a}$ & 36 \\
Test. $\mathrm{H}_{2} \mathrm{O}$ & $36 \mathrm{~b}$ & 37 & $37 \mathrm{~b}$ & 38 \\
\hline
\end{tabular}

Médias seguidas da mesma letra na coluna não diferem entre si pelo Teste de Tukey a 5\% ${ }^{\text {ns }}$ não significativo 


\subsection{Conclusões}

1. Reduções significativas na produção de grãos (t/ha) e peso de espiga (g) foram observados apenas para o híbrido suscetível (H8621) quando as plantas foram inoculadas aos 20 dias após a emergência.

2. O comprimento médio de lesão em cada híbrido não diferiu em função da época de inoculação do patógeno.

3. Os danos na produção de grãos para o híbrido suscetível quando inoculado aos 20 dias após a emergência podem ser atribuídos a menor taxa de acumulação de fotoassimilados nos colmos bem como a redução do número de plantas viáveis nas parcelas.

4. Este é o primeiro relato de estimativas de danos na produção de grãos de híbridos de milho oriundos de germoplasma tropical. Estes resultados devem ser considerados na seleção de plantas de milho resistentes a este patógeno. 


\section{CONCLUSÕES GERAIS}

1. Os métodos de inoculação de C. graminicola e de avaliação dos sintomas de podridão do colmo foram eficientes em detectar diferenças no nível de resistência entre plantas.

2. O modo de herança da resistência genética de milho à antracnose do colmo em germoplasma tropical é variável e dependente da constituição genética das linhagens genitoras resistentes analisadas.

3. Os resultados da análise de média de gerações foram confirmados pelos resultados de mapeamento molecular de genes de resistência na família Das86 x Das21.

4. As reduções na produção de grãos de milho ocasionadas pela inoculação de C. graminicola em genótipos suscetíveis são relevantes. 
ANEXOS 
Tabela 7. Médias ajustadas do comprimento de lesão $(\mathrm{cm})$ de C. graminicola submetidas ao teste de agrupamento de Scott-Knott para as três épocas de semeadura e médias da análise conjunta

\begin{tabular}{|c|c|c|c|c|c|c|c|}
\hline \multicolumn{2}{|c|}{ Ensaio 1} & \multicolumn{2}{|c|}{ Ensaio 2} & \multicolumn{2}{|c|}{ Ensaio 3} & \multicolumn{2}{|c|}{ Conjunta } \\
\hline Tratamento & Média & Tratamento & Média & Tratamento & Média & Tratamento & Média \\
\hline $\mathrm{H}$ & $54,2 \mathrm{a}$ * & 242 & $89,6 a$ * & $\mathrm{H}$ & $72,6 \mathrm{a}$ * & $\mathrm{H}$ & $66,0 \mathrm{a}$ * \\
\hline 130 & $51,4 \mathrm{a}$ & 224 & $88,4 a$ & 65 & $54,0 \mathrm{~b}$ & 224 & $60,8 \mathrm{a}$ \\
\hline 116 & $49,8 \mathrm{a}$ & 178 & $82,7 \mathrm{a}$ & 224 & $50,8 \mathrm{~b}$ & 242 & $59,1 \mathrm{a}$ \\
\hline 170 & $45,5 \mathrm{a}$ & 199 & $71,8 \mathrm{~b}$ & 120 & $48,6 \mathrm{~b}$ & 65 & $53,8 \mathrm{a}$ \\
\hline 27 & $44,7 \mathrm{a}$ & 112 & $71,5 \mathrm{~b}$ & 223 & $47,9 \mathrm{~b}$ & 178 & $51,7 \mathrm{a}$ \\
\hline 153 & $44,1 \mathrm{a}$ & $\mathrm{H}$ & $71,1 \mathrm{~b}$ & 102 & $46,4 \mathrm{c}$ & 199 & $50,9 a$ \\
\hline 223 & $43,8 \mathrm{a}$ & 71 & $70,0 \mathrm{~b}$ & 242 & $45,3 \mathrm{c}$ & 209 & $50,4 \mathrm{a}$ \\
\hline 224 & $43,1 \mathrm{a}$ & 209 & $69,4 \mathrm{~b}$ & 49 & $45,2 \mathrm{c}$ & 223 & $48,7 \mathrm{~b}$ \\
\hline 65 & $43,1 \mathrm{a}$ & 186 & $68,5 \mathrm{~b}$ & 159 & $45,1 \mathrm{c}$ & 14 & $48,4 \mathrm{~b}$ \\
\hline 14 & $42,7 \mathrm{a}$ & 115 & $67,1 \mathrm{~b}$ & 71 & $43,8 \mathrm{c}$ & 71 & $48,1 \mathrm{~b}$ \\
\hline 73 & $42,7 \mathrm{a}$ & 14 & $66,8 \mathrm{~b}$ & 209 & $43,3 \mathrm{c}$ & 130 & $47,6 \mathrm{~b}$ \\
\hline 242 & $42,6 \mathrm{a}$ & 55 & $65,8 \mathrm{~b}$ & 153 & $42,8 \mathrm{c}$ & 49 & $47,4 \mathrm{~b}$ \\
\hline 179 & $42,5 \mathrm{a}$ & 65 & $64,1 \mathrm{~b}$ & 228 & $42,6 \mathrm{c}$ & 55 & $46,9 \mathrm{~b}$ \\
\hline 228 & $42,2 \mathrm{a}$ & 130 & $62,8 \mathrm{~b}$ & 42 & $42,5 \mathrm{c}$ & 186 & $46,6 \mathrm{~b}$ \\
\hline 181 & $41,9 a$ & 80 & $61,9 \mathrm{~b}$ & 149 & $42,0 \mathrm{c}$ & 80 & $46,1 \mathrm{~b}$ \\
\hline 235 & $41,8 \mathrm{a}$ & 95 & $61,6 \mathrm{~b}$ & 66 & $42,0 \mathrm{c}$ & 115 & $45,8 \mathrm{~b}$ \\
\hline 244 & $41,4 \mathrm{a}$ & 49 & $61,1 \mathrm{~b}$ & 188 & $42,0 \mathrm{c}$ & 23 & $45,2 \mathrm{~b}$ \\
\hline 19 & $41,3 a$ & 23 & $59,9 \mathrm{~b}$ & Das86 & $41,7 \mathrm{c}$ & 116 & $44,9 \mathrm{~b}$ \\
\hline 80 & $41,0 \mathrm{a}$ & 170 & 59,8 b & 82 & $40,7 \mathrm{c}$ & 112 & $44,8 \mathrm{~b}$ \\
\hline 77 & $41,0 \mathrm{a}$ & 163 & $58,3 \mathrm{c}$ & 199 & $40,5 \mathrm{c}$ & 228 & $44,8 \mathrm{~b}$ \\
\hline 191 & $40,9 a$ & 116 & $54,9 \mathrm{c}$ & 190 & $39,9 \mathrm{c}$ & 191 & $43,6 \mathrm{~b}$ \\
\hline 199 & $40,5 \mathrm{a}$ & 223 & $54,5 \mathrm{c}$ & 55 & $39,5 \mathrm{c}$ & 170 & $43,6 \mathrm{~b}$ \\
\hline 145 & $40,3 a$ & 113 & $54,1 \mathrm{c}$ & 72 & $38,9 \mathrm{c}$ & 159 & $43,5 b$ \\
\hline 23 & $40,1 \mathrm{a}$ & 191 & $53,0 \mathrm{c}$ & 132 & $38,9 \mathrm{c}$ & 95 & $43,2 b$ \\
\hline 70 & $39,9 a$ & 145 & $51,6 \mathrm{c}$ & 180 & $38,8 \mathrm{c}$ & 153 & $42,1 \mathrm{~b}$ \\
\hline 113 & $39,8 \mathrm{a}$ & 82 & $51,6 \mathrm{c}$ & 107 & $38,5 \mathrm{c}$ & 163 & $41,9 \mathrm{~b}$ \\
\hline 159 & $39,2 \mathrm{a}$ & 127 & $49,8 \mathrm{c}$ & 244 & $38,4 \mathrm{c}$ & 120 & $41,8 \mathrm{~b}$ \\
\hline 57 & $38,6 \mathrm{a}$ & 228 & $49,5 \mathrm{c}$ & 103 & $38,4 \mathrm{c}$ & 113 & $41,5 b$ \\
\hline
\end{tabular}


Tabela 7. Médias ajustadas do comprimento de lesão $(\mathrm{cm})$ de C. graminicola submetidas ao teste de agrupamento de Scott-Knott para as três épocas de semeadura e médias da análise conjunta

\begin{tabular}{|c|c|c|c|c|c|c|c|}
\hline \multicolumn{2}{|c|}{ Ensaio 1} & \multicolumn{2}{|c|}{ Ensaio 2} & \multicolumn{2}{|c|}{ Ensaio 3} & \multicolumn{2}{|c|}{ Conjunta } \\
\hline Tratamento & Média & Tratamento & Média & Tratamento & Média & Tratamento & Média \\
\hline 11 & $38,6 \mathrm{a}$ & 146 & $48,9 \mathrm{c}$ & 31 & $38,1 \mathrm{c}$ & 82 & $40,7 \mathrm{~b}$ \\
\hline 209 & $38,6 \mathrm{a}$ & 16 & $48,8 \mathrm{c}$ & 99 & $38,0 \mathrm{c}$ & 244 & $39,9 \mathrm{~b}$ \\
\hline 43 & $38,3 \mathrm{a}$ & 159 & $46,2 \mathrm{c}$ & 94 & $37,9 \mathrm{c}$ & 180 & $39,7 \mathrm{~b}$ \\
\hline 177 & $38,2 \mathrm{a}$ & 13 & $44,9 \mathrm{c}$ & 225 & $37,8 \mathrm{c}$ & 145 & $39,7 \mathrm{~b}$ \\
\hline 243 & $37,8 \mathrm{a}$ & 214 & $44,3 \mathrm{c}$ & 88 & $37,7 \mathrm{c}$ & 102 & $39,1 \mathrm{~b}$ \\
\hline 189 & $37,7 \mathrm{a}$ & 103 & $43,8 \mathrm{c}$ & 235 & $37,5 \mathrm{c}$ & 70 & $39,0 \mathrm{~b}$ \\
\hline 131 & $37,3 \mathrm{a}$ & 180 & $43,4 \mathrm{c}$ & 151 & $37,3 \mathrm{c}$ & 179 & $38,9 \mathrm{~b}$ \\
\hline 211 & $37,2 \mathrm{a}$ & 135 & $43,2 \mathrm{c}$ & 59 & $37,3 \mathrm{c}$ & 127 & $38,6 \mathrm{~b}$ \\
\hline 180 & $37,1 \mathrm{a}$ & 120 & $41,6 \mathrm{~d}$ & 211 & $37,3 \mathrm{c}$ & 109 & $38,6 \mathrm{~b}$ \\
\hline 163 & $36,6 \mathrm{a}$ & 124 & $41,3 d$ & 86 & $37,2 \mathrm{c}$ & 235 & $38,0 \mathrm{~b}$ \\
\hline Das86 & $36,5 \mathrm{a}$ & 70 & $41,3 d$ & 67 & $37,1 \mathrm{c}$ & 211 & $37,8 \mathrm{~b}$ \\
\hline 178 & $36,5 \mathrm{a}$ & 244 & $39,8 d$ & 47 & $37,1 \mathrm{c}$ & 181 & $37,7 \mathrm{~b}$ \\
\hline 49 & $35,9 a$ & 153 & $39,5 d$ & 181 & $37,0 \mathrm{c}$ & 146 & $37,1 \mathrm{~b}$ \\
\hline 204 & $35,6 \mathrm{a}$ & 211 & $38,9 d$ & 115 & $37,0 \mathrm{c}$ & 16 & $37,0 \mathrm{~b}$ \\
\hline 88 & $35,6 \mathrm{a}$ & 102 & $38,4 \mathrm{~d}$ & 179 & $37,0 \mathrm{c}$ & Das86 & $36,2 \mathrm{c}$ \\
\hline 55 & $35,3 a$ & 131 & $37,6 \mathrm{~d}$ & 191 & $37,0 \mathrm{c}$ & 149 & $36,2 \mathrm{c}$ \\
\hline 120 & $35,3 a$ & 94 & $37,5 d$ & 186 & $36,8 \mathrm{c}$ & 188 & $36,2 \mathrm{c}$ \\
\hline 66 & $35,3 a$ & 179 & $37,2 \mathrm{~d}$ & 34 & $36,1 \mathrm{c}$ & 132 & $35,9 \mathrm{c}$ \\
\hline 186 & $34,6 \mathrm{~b}$ & 46 & $37,2 \mathrm{~d}$ & 46 & $36,1 \mathrm{c}$ & 94 & $35,7 \mathrm{c}$ \\
\hline 132 & $34,4 \mathrm{~b}$ & 59 & $36,6 \mathrm{~d}$ & 178 & $35,8 \mathrm{c}$ & 66 & $35,5 \mathrm{c}$ \\
\hline 111 & $34,3 \mathrm{~b}$ & 188 & $36,2 d$ & 70 & $35,8 \mathrm{c}$ & 46 & $35,5 \mathrm{c}$ \\
\hline 81 & $34,3 \mathrm{~b}$ & 235 & $34,8 \mathrm{~d}$ & 152 & $35,6 \mathrm{c}$ & 214 & $35,3 \mathrm{c}$ \\
\hline 190 & $34,2 \mathrm{~b}$ & 149 & $34,7 \mathrm{~d}$ & 14 & $35,6 \mathrm{c}$ & 135 & $34,6 \mathrm{c}$ \\
\hline 95 & $34,2 \mathrm{~b}$ & 132 & $34,4 \mathrm{~d}$ & 104 & $35,6 \mathrm{c}$ & 73 & $33,9 \mathrm{c}$ \\
\hline 103 & $33,7 \mathrm{~b}$ & 229 & $34,3 d$ & 23 & $35,6 \mathrm{c}$ & 152 & $33,9 \mathrm{c}$ \\
\hline 127 & $33,6 \mathrm{~b}$ & 181 & $34,2 \mathrm{~d}$ & 80 & $35,4 \mathrm{c}$ & 42 & $33,8 \mathrm{c}$ \\
\hline 61 & $33,5 b$ & 161 & $33,9 d$ & 76 & $34,8 d$ & 47 & $33,6 \mathrm{c}$ \\
\hline 115 & $33,3 \mathrm{~b}$ & 152 & $32,9 d$ & 214 & $34,6 \mathrm{~d}$ & 59 & $33,4 \mathrm{c}$ \\
\hline
\end{tabular}


Tabela 7. Médias ajustadas do comprimento de lesão $(\mathrm{cm})$ de C. graminicola submetidas ao teste de agrupamento de Scott-Knott para as três épocas de semeadura e médias da análise conjunta

\begin{tabular}{|c|c|c|c|c|c|c|c|}
\hline \multicolumn{2}{|c|}{ Ensaio 1} & \multicolumn{2}{|c|}{ Ensaio 2} & \multicolumn{2}{|c|}{ Ensaio 3} & \multicolumn{2}{|c|}{ Conjunta } \\
\hline Tratamento & Média & Tratamento & Média & Tratamento & Média & Tratamento & Média \\
\hline 34 & $33,2 \mathrm{~b}$ & 138 & $32,7 \mathrm{~d}$ & 229 & $34,2 d$ & 104 & $33,2 \mathrm{c}$ \\
\hline 152 & $33,1 \mathrm{~b}$ & 47 & $32,5 d$ & 95 & $33,9 d$ & 27 & $32,9 \mathrm{c}$ \\
\hline 46 & $33,1 \mathrm{~b}$ & 104 & $31,7 \mathrm{~d}$ & 243 & $33,9 \mathrm{~d}$ & 77 & $32,8 \mathrm{c}$ \\
\hline 137 & $32,8 \mathrm{~b}$ & Das86 & $30,5 d$ & 58 & $33,8 d$ & 19 & $32,8 \mathrm{c}$ \\
\hline 67 & $32,7 \mathrm{~b}$ & 77 & $30,4 \mathrm{~d}$ & 112 & $33,6 \mathrm{~d}$ & 13 & $32,7 \mathrm{c}$ \\
\hline 102 & $32,5 \mathrm{~b}$ & 76 & $30,2 \mathrm{~d}$ & 73 & $33,5 d$ & 229 & $32,7 \mathrm{c}$ \\
\hline 104 & $32,5 \mathrm{~b}$ & 42 & $30,0 \mathrm{~d}$ & 123 & $33,5 d$ & 34 & $32,5 \mathrm{c}$ \\
\hline 86 & $32,4 \mathrm{~b}$ & 35 & $29,8 d$ & 51 & $33,0 \mathrm{~d}$ & 131 & $32,4 \mathrm{c}$ \\
\hline 10 & $31,9 \mathrm{~b}$ & 66 & $29,3 d$ & 177 & $32,9 d$ & 177 & $32,2 \mathrm{c}$ \\
\hline 149 & $31,9 \mathrm{~b}$ & 34 & $28,3 d$ & 133 & $32,8 d$ & 138 & $32,2 \mathrm{c}$ \\
\hline 94 & $31,7 \mathrm{~b}$ & 31 & $27,7 \mathrm{~d}$ & 19 & $32,7 \mathrm{~d}$ & 31 & $32,1 \mathrm{c}$ \\
\hline 16 & $31,6 \mathrm{~b}$ & 205 & $27,5 \mathrm{~d}$ & 146 & $32,6 \mathrm{~d}$ & 190 & $32,1 \mathrm{c}$ \\
\hline 1 & $31,5 \mathrm{~b}$ & 133 & $26,4 \mathrm{~d}$ & 127 & $32,5 d$ & 88 & $31,6 \mathrm{c}$ \\
\hline 138 & $31,4 \mathrm{~b}$ & 99 & $26,1 \mathrm{~d}$ & 35 & $32,4 \mathrm{~d}$ & 67 & $31,5 \mathrm{c}$ \\
\hline 136 & $31,3 \mathrm{~b}$ & 177 & $25,6 \mathrm{~d}$ & 138 & $32,4 \mathrm{~d}$ & 76 & $31,3 \mathrm{c}$ \\
\hline 47 & $31,1 \mathrm{~b}$ & 73 & $25,5 d$ & 27 & $32,2 \mathrm{~d}$ & 124 & $31,1 \mathrm{c}$ \\
\hline 58 & $30,9 \mathrm{~b}$ & 125 & $24,9 \mathrm{e}$ & 135 & $31,8 d$ & 225 & $30,7 \mathrm{c}$ \\
\hline 51 & $30,7 \mathrm{~b}$ & 246 & $24,9 \mathrm{e}$ & 156 & $31,7 \mathrm{~d}$ & 35 & $30,3 \mathrm{c}$ \\
\hline 31 & $30,5 \mathrm{~b}$ & 67 & $24,8 \mathrm{e}$ & 111 & $31,5 d$ & 43 & $30,0 \mathrm{c}$ \\
\hline 71 & $30,3 \mathrm{~b}$ & 107 & $24,4 \mathrm{e}$ & 163 & $31,2 d$ & 189 & $29,8 \mathrm{c}$ \\
\hline 119 & $30,3 \mathrm{~b}$ & 19 & $24,3 \mathrm{e}$ & 119 & $31,0 \mathrm{~d}$ & 86 & $29,7 \mathrm{c}$ \\
\hline 64 & $30,3 \mathrm{~b}$ & 225 & $24,3 \mathrm{e}$ & 113 & $30,7 \mathrm{~d}$ & 161 & $29,6 \mathrm{c}$ \\
\hline 188 & $30,3 \mathrm{~b}$ & 72 & $23,9 \mathrm{e}$ & 189 & $30,6 \mathrm{~d}$ & 243 & $29,6 \mathrm{c}$ \\
\hline 141 & $30,3 \mathrm{~b}$ & 79 & $23,9 \mathrm{e}$ & 195 & $30,6 \mathrm{~d}$ & 107 & $29,5 \mathrm{c}$ \\
\hline 123 & $30,2 \mathrm{~b}$ & 81 & $23,2 \mathrm{e}$ & 16 & $30,6 \mathrm{~d}$ & 99 & $29,0 \mathrm{c}$ \\
\hline 225 & $30,1 b$ & 137 & $22,6 \mathrm{e}$ & 246 & $30,5 d$ & 81 & $29,0 \mathrm{c}$ \\
\hline 79 & $30,1 \mathrm{~b}$ & 30 & $22,6 \mathrm{e}$ & 61 & $30,4 \mathrm{~d}$ & 51 & $28,6 \mathrm{c}$ \\
\hline 109 & 29,6 b & 190 & $22,1 \mathrm{e}$ & 28 & $30,3 d$ & 133 & $28,6 \mathrm{c}$ \\
\hline
\end{tabular}


Tabela 7. Médias ajustadas do comprimento de lesão $(\mathrm{cm})$ de C. graminicola submetidas ao teste de agrupamento de Scott-Knott para as três épocas de semeadura e médias da análise conjunta

\begin{tabular}{|c|c|c|c|c|c|c|c|}
\hline \multicolumn{2}{|c|}{ Ensaio 1} & \multicolumn{2}{|c|}{ Ensaio 2} & \multicolumn{2}{|c|}{ Ensaio 3} & \multicolumn{2}{|c|}{ Conjunta } \\
\hline Tratamento & Média & Tratamento & Média & Tratamento & Média & Tratamento & Média \\
\hline 121 & $29,9 \mathrm{~b}$ & 51 & $22,1 \mathrm{e}$ & 79 & $30,1 d$ & 72 & $28,6 \mathrm{c}$ \\
\hline 146 & $29,9 \mathrm{~b}$ & 43 & $22,1 \mathrm{e}$ & 91 & $30,1 \mathrm{~d}$ & 123 & $28,4 \mathrm{c}$ \\
\hline 82 & $29,8 \mathrm{~b}$ & 27 & $21,7 \mathrm{e}$ & 205 & $29,9 d$ & 137 & $28,3 \mathrm{c}$ \\
\hline 253 & $29,8 \mathrm{~b}$ & 123 & $21,6 \mathrm{e}$ & 116 & $29,8 d$ & 79 & $28,0 \mathrm{c}$ \\
\hline 229 & $29,5 \mathrm{~b}$ & 88 & $21,5 \mathrm{e}$ & 12 & $29,7 d$ & 61 & $27,8 \mathrm{c}$ \\
\hline 112 & $29,4 \mathrm{~b}$ & 1 & $21,2 \mathrm{e}$ & 43 & $29,6 \mathrm{~d}$ & 58 & $27,2 \mathrm{c}$ \\
\hline 79 & $30,1 \mathrm{~b}$ & 189 & 20,9 e & 125 & $29,5 d$ & 125 & $26,9 \mathrm{c}$ \\
\hline 42 & $29,0 \mathrm{~b}$ & 61 & $19,5 \mathrm{e}$ & 144 & $29,5 d$ & 246 & $26,8 \mathrm{c}$ \\
\hline 135 & $28,8 \mathrm{~b}$ & 86 & $19,5 \mathrm{e}$ & 137 & $29,5 d$ & 205 & $26,8 \mathrm{c}$ \\
\hline 161 & $28,6 \mathrm{~b}$ & 195 & $17,3 \mathrm{e}$ & 81 & $29,4 d$ & 1 & $26,5 \mathrm{c}$ \\
\hline 35 & $28,5 \mathrm{~b}$ & 243 & $17,1 \mathrm{e}$ & 87 & $29,3 d$ & 119 & $25,8 \mathrm{c}$ \\
\hline 91 & $28,4 \mathrm{~b}$ & 58 & $17,0 \mathrm{e}$ & 122 & $28,7 \mathrm{~d}$ & 111 & $25,3 \mathrm{c}$ \\
\hline 87 & $28,1 \mathrm{~b}$ & 200 & $16,7 \mathrm{e}$ & 130 & $28,5 d$ & 195 & $25,3 \mathrm{c}$ \\
\hline 195 & $28,0 \mathrm{~b}$ & 28 & $16,5 \mathrm{e}$ & 124 & $28,2 d$ & 151 & $25,2 \mathrm{c}$ \\
\hline 12 & $27,6 \mathrm{~b}$ & 143 & $16,2 \mathrm{e}$ & 69 & $28,0 \mathrm{~d}$ & 11 & $25,0 \mathrm{c}$ \\
\hline 214 & $27,1 \mathrm{~b}$ & 119 & $16,0 \mathrm{e}$ & 11 & $27,6 \mathrm{~d}$ & 10 & $24,6 \mathrm{c}$ \\
\hline 13 & $26,6 \mathrm{~b}$ & 122 & $15,9 \mathrm{e}$ & 200 & $27,5 d$ & 12 & $24,3 \mathrm{c}$ \\
\hline 133 & $26,6 \mathrm{~b}$ & 12 & $15,7 \mathrm{e}$ & 109 & $27,5 d$ & 121 & $24,0 \mathrm{c}$ \\
\hline 30 & $26,4 \mathrm{~b}$ & 10 & $15,0 \mathrm{e}$ & 185 & $27,5 d$ & 204 & $23,9 \mathrm{c}$ \\
\hline 59 & $26,3 \mathrm{~b}$ & 151 & $14,8 \mathrm{e}$ & 204 & $27,4 \mathrm{~d}$ & 30 & $23,8 \mathrm{c}$ \\
\hline 125 & $26,1 \mathrm{~b}$ & 121 & $14,8 \mathrm{e}$ & 121 & $27,2 \mathrm{~d}$ & 136 & $23,7 \mathrm{c}$ \\
\hline 200 & $26,1 \mathrm{~b}$ & 156 & $14,0 \mathrm{e}$ & 77 & $27,1 \mathrm{~d}$ & 57 & $23,6 \mathrm{c}$ \\
\hline 122 & $25,7 \mathrm{~b}$ & 185 & $13,7 \mathrm{e}$ & Das21 & $27,1 \mathrm{~d}$ & 122 & $23,4 \mathrm{c}$ \\
\hline 107 & $25,6 \mathrm{~b}$ & 136 & $13,4 \mathrm{e}$ & 145 & $27,1 \mathrm{~d}$ & 200 & $23,4 \mathrm{c}$ \\
\hline 185 & $25,4 \mathrm{~b}$ & 69 & $12,9 \mathrm{e}$ & 10 & $26,8 d$ & 91 & $23,4 \mathrm{c}$ \\
\hline 246 & $24,9 \mathrm{~b}$ & 87 & $12,4 \mathrm{e}$ & 143 & $26,8 d$ & 87 & $23,3 \mathrm{c}$ \\
\hline 144 & $24,4 \mathrm{~b}$ & 144 & $12,1 \mathrm{e}$ & 1 & $26,8 d$ & 156 & $23,1 \mathrm{c}$ \\
\hline Das21 & 24,2 b & 91 & $11,7 \mathrm{e}$ & 13 & $26,5 d$ & 185 & $22,2 \mathrm{c}$ \\
\hline
\end{tabular}


Tabela 7. Médias ajustadas do comprimento de lesão $(\mathrm{cm})$ de C. graminicola submetidas ao teste de agrupamento de Scott-Knott para as três épocas de semeadura e médias da análise conjunta

\begin{tabular}{cccccccc}
\hline \multicolumn{2}{c}{ Ensaio 1 } & \multicolumn{2}{c}{ Ensaio 2 } & \multicolumn{2}{c}{ Ensaio 3 } & \multicolumn{2}{c}{ Conjunta } \\
\hline Tratamento & Média & Tratamento & Média & Tratamento & Média & Tratamento & Média \\
& & & & & & & \\
\hline 124 & $23,9 \mathrm{~b}$ & 111 & $10,2 \mathrm{e}$ & 136 & $26,5 \mathrm{~d}$ & 144 & $22,0 \mathrm{c}$ \\
159 & $39,2 \mathrm{~b}$ & 253 & $9,6 \mathrm{e}$ & 64 & $26,5 \mathrm{~d}$ & 109 & $21,9 \mathrm{c}$ \\
151 & $23,5 \mathrm{~b}$ & Das21 & $9,0 \mathrm{e}$ & 161 & $26,4 \mathrm{~d}$ & 253 & $21,3 \mathrm{c}$ \\
205 & $22,9 \mathrm{~b}$ & 11 & $8,7 \mathrm{e}$ & 141 & $25,7 \mathrm{~d}$ & 28 & $21,3 \mathrm{c}$ \\
99 & $22,9 \mathrm{~b}$ & 204 & $8,6 \mathrm{e}$ & 170 & $25,2 \mathrm{~d}$ & 64 & $21,1 \mathrm{c}$ \\
72 & $22,8 \mathrm{~b}$ & 109 & $8,3 \mathrm{e}$ & 253 & $24,7 \mathrm{~d}$ & 143 & $21,0 \mathrm{c}$ \\
69 & $20,2 \mathrm{~b}$ & 57 & $7,9 \mathrm{e}$ & 57 & $24,2 \mathrm{~d}$ & 141 & $21,0 \mathrm{c}$ \\
143 & $20,2 \mathrm{~b}$ & 141 & $7,1 \mathrm{e}$ & 131 & $22,5 \mathrm{~d}$ & 69 & $20,4 \mathrm{c}$ \\
28 & $17,1 \mathrm{~b}$ & 64 & $6,5 \mathrm{e}$ & 30 & $22,3 \mathrm{~d}$ & Das21 & $20,1 \mathrm{c}$ \\
\hline
\end{tabular}

* médias seguidas de mesma letra minúscula na coluna não diferem entre si pelo Teste de Scott-Knott 
Tabela 8. Locos microssatélites testados nas linhagens Das21 e Das86, suas localizações cromossômicas (Bin) e resultados da amplificação por $\mathrm{PCR}(\mathrm{P}=$ polimórfico, $\mathrm{M}=$ monomórfico e $\mathrm{NA}=$ não amplificado)

\begin{tabular}{|c|c|c|c|c|c|c|c|c|}
\hline Loco SSR & “Bin” & $\mathrm{PCR}^{\star \star}$ & Loco SSR & "Bin" & PCR & Loco SSR & "Bin" & PCR \\
\hline Bnlg 149 & 1.00 & $P$ * & Bnlg 372 & 4.00 & NA & Bnlg 345 & 6.05 & $M$ \\
\hline phi 056 & 1.01 & $P *$ & Phi 072 & 4.01 & $\mathrm{P}$ & Phi 078 & 6.05 & $\mathrm{M}$ \\
\hline phi 097 & 1.01 & M & Nc 004 & 4.03 & M & Nc 012 & 6.05 & $\mathrm{P}$ \\
\hline Bnlg 109 & 1.02 & $M$ & Phi 021 & 4.03 & $M$ & Phi 070 & 6.06 & $M$ \\
\hline Bnlg 176 & 1.02 & $\mathrm{M}$ & Phi 074 & 4.04 & $M$ & Bnlg 1686 & 7.00 & $M$ \\
\hline Bnlg 1007 & 1.02 & $P$ * & Nc 005 & 4.05 & M & Bnlg 1292 & 7.01 & $P$ \\
\hline Bnlg 182 & 1.03 & M & Phi 079 & 4.05 & M & Phi 112 & 7.01 & NA \\
\hline phi 001 & 1.03 & M & Phi 026 & 4.05 & M & Phi 057 & 7.01 & $\mathrm{M}$ \\
\hline Bnlg 439 & 1.03 & $\mathrm{P}$ & Phi 096 & 4.05 & $\mathrm{M}$ & Phi 034 & 7.02 & $P$ * \\
\hline Bnlg 147 & 1.03 & M & Bnlg 667 & 4.05 & NA & Bnlg 657 & 7.02 & $P$ \\
\hline phi 095 & 1.03 & M & Bnlg 490 & 4.05 & $\mathrm{P}$ & Phi 114 & 7.02 & $\mathrm{M}$ \\
\hline Bnlg 652 & 1.04 & $M$ & Bnlg 252 & 4.05 & $M$ & Bnlg 398 & 7.02 & $M$ \\
\hline Bnlg 1016 & 1.04 & $\mathrm{P}$ & Bnlg 2291 & 4.06 & $P$ * & Bnlg 434 & 7.03 & $\mathrm{P}$ \\
\hline Bnlg 421 & 1.06 & $M$ & Mttgb02 & 4.07 & $\mathrm{P}$ * & Bnlg 155 & 7.03 & M \\
\hline Bnlg 615 & 1.07 & M & Bnlg 1784 & 4.07 & M & Bnlg 339 & 7.03 & $P *$ \\
\hline Phi 055 & 1.09 & M & Bnlg 1189 & 4.07 & M & Bnlg 572 & 7.03 & M \\
\hline Phi 094 & 1.09 & M & Phi 093 & 4.08 & M & Bnlg 161 & 7.04 & $\mathrm{P}$ \\
\hline Bnlg 100 & 1.09 & M & Phi 092 & 4.08 & $M$ & Bnlg 1161 & 7.04 & $\mathrm{M}$ \\
\hline Phi 011 & 1.09 & $\mathrm{M}$ & Bnlg 292a & $4.08 / 4.09$ & $\mathrm{M}$ & Bnlg 666 & 8.02 & $\mathrm{P}$ \\
\hline Bnlg 400 & 1.09 & NA & Bnlg 1565 & 4.09 & $P$ & Bnlg 162 & 8.03 & $M$ \\
\hline Bnlg 504 & 1.11 & $\mathrm{P}$ & Bnlg 1589 & 4.10 & $P$ * & Bnlg 669 & 8.03 & $\mathrm{M}$ \\
\hline Bnlg 131 & 1.11 & $P *$ & Phi 006 & 4.10 & $P$ & Bnlg 119 & 8.04 & Ref \\
\hline Phi 064 & 1.11 & M & Phi 019 & 4.11 & M & Phi 060 & 8.04 & NA \\
\hline Bnlg 257 & 1.12 & $M$ & Phi 076 & 4.11 & M & Phi115 & 8.03 & $P$ * \\
\hline Bnlg 1092 & 2.01 & M & Phi 024 & 5.00 & M & Phi 014 & 8.04 & $P$ * \\
\hline Bnlg 469 & 2.02 & M & Nc 007 & 5.00 & M & Bnlg 240 & 8.06 & $P$ * \\
\hline Bnlg 1017 & 2.02 & M & Mace0b03 & 5.01 & $\mathrm{P}$ & Phi 080 & 8.08 & $\mathrm{M}$ \\
\hline Bnlg 125 & 2.03 & $P$ * & Bnlg 143 & 5.01 & $\mathrm{M}$ & Mact2b08 & 9.01 & $P$ * \\
\hline Bnlg 381 & 2.03 & M & Bnlg 565 & 5.02 & NA & Phi 068 & 9.01 & $\mathrm{M}$ \\
\hline Mmc 063 & $2.00 / 2.04$ & $M$ & Phi 113 & 5.02 & $M$ & Phi 033 & 9.01 & $P$ \\
\hline Bnlg 108 & 2.04 & $P$ & Bnlg 105 & 5.03 & $\mathrm{M}$ & Bnlg 2122 & 9.01 & $\mathrm{M}$ \\
\hline Bnlg 121 & 2.04 & $M$ & Phi 008 & 5.03 & NA & Phi 028 & 9.01 & $\mathrm{P}$ \\
\hline Phi 083 & 2.04 & $P$ & Bnlg 557 & 5.03 & $P *$ & Umc 1033 & 9.02 & $\mathrm{P}$ \\
\hline Bnlg 166 & 2.04 & M & Bnlg 150 & 5.04 & $\mathrm{P}$ & Umc 1037 & 9.02 & $\mathrm{P}$ \\
\hline Mage05 & $2.05 / 2.06$ & $\mathrm{P}$ * & Bnlg 603 & 5.04 & NA & Phi 017 & 9.02 & $M$ \\
\hline Nc 003 & 2.06 & $\mathrm{M}$ & Bnlg 653 & 5.04 & $\mathrm{M}$ & Bnlg 244 & 9.02 & M \\
\hline Bnlg 180 & 2.05 & $\mathrm{P}$ & Bnlg 278 & 5.05 & $P *$ & Phi 065 & 9.03 & $P$ * \\
\hline Bnlg 371 & 2.05 & M & Bnlg 609 & 5.06 & NA & Phi 022 & 9.03 & M \\
\hline Mmc 191 & $2.07 / 2.08$ & $P *$ & Phi 085 & 5.07 & $\mathrm{M}$ & Phi 027 & 9.03 & $P$ * \\
\hline Mmc 271 & 2.07 & NA & Bnlg 1306 & 5.07 & $\mathrm{M}$ & Phi 061 & 9.03 & $\mathrm{P}$ \\
\hline Bnlg 1045 & 2.07 & $\mathrm{P}$ & Bnlg 118 & 5.08 & M & Mmc 051 & 9.03 & $\mathrm{P}$ \\
\hline Phi 127 & 2.08 & M & Bnlg 389 & 5.09 & M & Phi 032 & 9.04 & M \\
\hline Bnlg 198 & 2.08 & $P$ & Bnlg 386 & 5.09 & $M$ & Phi 042 & 9.04 & $M$ \\
\hline Mag1f03 & 2.08 & $P$ * & Phi 075 & 6.00 & $\mathrm{P}$ & Bnlg 127 & 9.04 & $\mathrm{P}$ \\
\hline
\end{tabular}


Tabela 8. Locos microssatélites testados nas linhagens Das21 e Das86, suas localizações cromossômicas (Bin) e resultados da amplificação por $\mathrm{PCR}(\mathrm{P}=$ polimórfico, $\mathrm{M}=$ monomórfico e $\mathrm{NA}=$ não amplificado)

\begin{tabular}{lccllclll}
\hline Loco SSR & "Bin" & PCR & Loco SSR & "Bin" & PCR & Loco SSR & "Bin" & PCR \\
\hline Mag1a01 & 2.08 & NA & Bnlg 249 & 6.01 & P * & Bnlg 619 & 9.07 & M \\
Phi 090 & 2.08 & M & Bnlg 391 & 6.01 & NA & Umc 1319 & 10.01 & P * \\
Bnlg 1520 & 2.09 & M & Bnlg 426 & 6.01 & P & Phi 059 & 10.02 & P \\
Nc 030 & 3.04 & NA & Bnlg 238 & 6.01 & P & Phi 063 & 10.02 & P \\
Bnlg 602 & 3.04 & P & Phi 077 & 6.01 & P * & Bnlg 210 & 10.03 & M \\
Phi 029 & 3.04 & P & Bnlg 107 & 6.01 & M & Phi 071 & 10.04 & M \\
Phi 073 & 3.05 & P & Bnlg 1371 & 6.02 & P & Phi 084 & 10.04 & M \\
Bnlg 420 & 3.05 & M & Nc 009 & 6.04 & NA & Bnlg 640 & 10.04 & P * \\
Phi 053 & 3.05 & M & Nc 010 & 6.04 & NA & Bnlg 137 & 10.05 & M \\
Bnlg 420 & 3.05 & P & Bnlg 480 & 6.04 & NA & Bnlg 236 & 10.06 & P \\
Bnlg 197 & 3.06 & P * & Phi 081 & 6.05 & M & Bnlg 279 & 10.07 & P \\
\hline
\end{tabular}

* primer SSR genotipado na população de mapeamento

** $\mathrm{P}, \mathrm{M}, \mathrm{NA}$ - polimórfico, monomórfico e não amplificado entre as linhagens genitoras 
Tabela 9. Distribuição cromossômica do número de locos microssatélites polimórficos, monomórficos e não amplificados testados entre as linhagens genitoras e número de locos genotipados na população de mapeamento

\begin{tabular}{lccccccccccc}
\hline & \multicolumn{10}{c}{ Cromossomo } \\
\cline { 2 - 12 } Loco Marcador & 1 & 2 & 3 & 4 & 5 & 6 & 7 & 8 & 9 & 10 & Total \\
\hline Polimórfico & 7 & 9 & 5 & 7 & 4 & 7 & 6 & 4 & 10 & 6 & 65 \\
Monomórfico & 16 & 12 & 3 & 15 & 11 & 5 & 7 & 3 & 8 & 4 & 84 \\
Sem Amplif. & 1 & 2 & 1 & 2 & 4 & 4 & 1 & 1 & 0 & 0 & 16 \\
Genotipados & 4 & 4 & 1 & 3 & 2 & 2 & 2 & 3 & 3 & 2 & 26 \\
\hline Total & 24 & 23 & 9 & 24 & 19 & 16 & 14 & 8 & 18 & 10 & \\
\hline
\end{tabular}


Tabela 10. Resultado do screening das combinações de primers EcoRI + Msel para as linhagens genitoras Das21 e Das86

\begin{tabular}{|c|c|c|c|c|c|}
\hline Número & Código Primer & Seqüência Primers & $\mathrm{N}^{0}$ Amplif. & $\mathrm{N}^{0}$ Polim. & \% Polim. \\
\hline 1 & E31 / M47 & E-AAA / M-CAA & 60 & 12 & 16,7 \\
\hline 2 & E31 / M48 & E-AAA / M-CAC & 57 & 10 & 14,9 \\
\hline 3 & E31 / M49 & E-AAA / M-CAG & 49 & 13 & 20,9 \\
\hline 4 & E31 / M50 & E-AAA / M-CAT & 71 & 15 & 17,4 \\
\hline 5 & E31 / M56 & E-AAA / M-CGC & 75 & 9 & 10,7 \\
\hline 6 & E31 / M58 & E-AAA / M-CGT & 45 & 14 & 23,7 \\
\hline 7 & E31 / M59 & E-AAA / M-CTA & 46 & 13 & 22,0 \\
\hline 8 & E31 / M60 & E-AAA / M-CTC & 58 & 11 & 15,9 \\
\hline 9 & E31 / M61 * & E-AAA / M-CTG & 58 & 12 & 17,1 \\
\hline 10 & E31 / M62 & E-AAA / M-CTT & 68 & 13 & 18,3 \\
\hline 11 & E32 / M47 & E-AAC / M-CAA & 89 & 25 & 21,9 \\
\hline 12 & E32 / M48 & E-AAC / M-CAC & 91 & 27 & 22,9 \\
\hline 13 & E32 / M49 & E-AAC / M-CAG & 84 & 15 & 15,1 \\
\hline 14 & E32 / M50 & E-AAC / M-CAT & 28 & 7 & 20,0 \\
\hline 15 & E32 / M56 & E-AAC / M-CGC & 78 & 16 & 17 \\
\hline 16 & E32 / M58 & E-AAC / M-CGT & 68 & 15 & 18,1 \\
\hline 17 & E32 / M59 & E-AAC / M-CTA & 67 & 14 & 17,3 \\
\hline 18 & E32 / M60 * & E-AAC / M-CTC & 56 & 20 & 23,3 \\
\hline 19 & E32 / M61 * & E-AAC / M-CTG & 44 & 16 & 26,7 \\
\hline 20 & E32 / M62 & E-AAC / M-CTT & 75 & 21 & 21,9 \\
\hline 21 & E33 / M47 & E-AAG / M-CAA & NA & NA & - \\
\hline 22 & E33 / M48 & E-AAG / M-CAC & 81 & 19 & 19,0 \\
\hline 23 & E33 / M49 & E-AAG / M-CAG & 58 & 16 & 21,6 \\
\hline 24 & E33 / M50 & E-AAG / M-CAT & 78 & 16 & 17,0 \\
\hline 25 & E33 / M56 & E-AAG / M-CGC & 65 & 18 & 21,7 \\
\hline 26 & E33 / M58 & E-AAG / M-CGT & 82 & 14 & 14,5 \\
\hline 27 & E33 / M59 * & E-AAG / M-CTA & 62 & 22 & 26,2 \\
\hline 28 & E33 / M60 & E-AAG / M-CTC & 90 & 19 & 17,4 \\
\hline 29 & E33 / M61 & E-AAG / M-CTG & 80 & 20 & 20,0 \\
\hline 30 & E33 / M62 & E-AAG / M-CTT & 48 & 23 & 32,4 \\
\hline 31 & E36 / M47 & E-ACC / M-CAA & 77 & 21 & 21,4 \\
\hline
\end{tabular}


Tabela 10. Resultado do screening das combinações de primers EcoRI + Msel para as linhagens genitoras Das21 e Das86

\begin{tabular}{|c|c|c|c|c|c|}
\hline Número & Código Primer & Seqüência Primers & $\mathrm{N}^{0}$ Amplif. & $\mathrm{N}^{0}$ Polim. & \% Polim. \\
\hline 32 & E36 / M48 * & E-ACC / M-CAC & 45 & 14 & 23,7 \\
\hline 33 & E36 / M49 & E-ACC / M-CAG & 56 & 19 & 25,3 \\
\hline 34 & E36 / M50 & E-ACC / M-CAT & 71 & 16 & 18,4 \\
\hline 35 & E36 / M56 & E-ACC / M-CGC & 62 & 16 & 20,5 \\
\hline 36 & E36 / M58 & E-ACC / M-CGT & 78 & 8 & 9,3 \\
\hline 37 & E36 / M59 & E-ACC / M-CTA & 84 & 30 & 26,3 \\
\hline 38 & E36 / M60 & E-ACC / M-CTC & 87 & 21 & 19,4 \\
\hline 39 & E36 / M61 & E-ACC/ M-CTG & 80 & 22 & 21,6 \\
\hline 40 & $\mathrm{E} 36 / \mathrm{M} 62$ * & E-ACC / M-CTT & 48 & 18 & 27,3 \\
\hline 41 & E37 / M47 & E-ACG / M-CAA & 73 & 11 & 13,1 \\
\hline 42 & E37 / M48 & E-ACG / M-CAC & 46 & 10 & 17,8 \\
\hline 43 & E37 / M49 & E-ACG / M-CAG & 55 & 7 & 11,3 \\
\hline 44 & $\mathrm{E} 37 / \mathrm{M} 50$ * & E-ACG / M-CAT & 38 & 17 & 30,9 \\
\hline 45 & E37 / M56 & E-ACG / M-CGC & 42 & 15 & 26,3 \\
\hline 46 & E37 / M58 & E-ACG / M-CGT & 59 & 11 & 15,7 \\
\hline 47 & E37 / M59 & E-ACG / M-CTA & 56 & 12 & 17,6 \\
\hline 48 & E37 / M60 & E-ACG / M-CTC & 35 & 13 & 27,1 \\
\hline 49 & E37 / M61 & E-ACG / M-CTG & 47 & 12 & 20,3 \\
\hline 50 & E37 / M62 & E-ACG / M-CTT & NA & NA & - \\
\hline 51 & E38 / M47 & E-ACT / M-CAA & 74 & 10 & 11,9 \\
\hline 52 & E38 / M48 & E-ACT / M-CAC & 86 & 15 & 14,8 \\
\hline 53 & E38 / M49 & E-ACT / M-CAG & 67 & 10 & 12,9 \\
\hline 54 & E38 / M50 & E-ACT / M-CAT & 77 & 16 & 17,2 \\
\hline 55 & E38 / M56 & E-ACT / M-CGC & 80 & 23 & 22,3 \\
\hline 56 & E38 / M58 & E-ACT / M-CGT & 40 & 8 & 16,7 \\
\hline 57 & E38 / M59 & E-ACT / M-CTA & 66 & 21 & 24,1 \\
\hline 58 & E38 / M60 & E-ACT / M-CTC & 74 & 13 & 14,9 \\
\hline 59 & E38 / M61 & E-ACT / M-CTG & 66 & 13 & 16,4 \\
\hline 60 & E38 / M62 & E-ACT / M-CTT & 72 & 7 & 8,8 \\
\hline 61 & E39 / M47 & E-AGA / M-CAA & 62 & 19 & 23,4 \\
\hline 62 & E39 / M48 & E-AGA / M-CAC & 92 & 21 & 18,6 \\
\hline
\end{tabular}


Tabela 10. Resultado do screening das combinações de primers EcoRI + Msel para as linhagens genitoras Das21 e Das86

\begin{tabular}{|c|c|c|c|c|c|}
\hline Número & Código Primer & Seqüência Primers & $\mathrm{N}^{0}$ Amplif. & $\mathrm{N}^{0}$ Polim. & \% Polim. \\
\hline 63 & E39 / M49 & E-AGA / M-CAG & NA & NA & - \\
\hline 64 & E39 / M50 & E-AGA / M-CAT & 81 & 16 & 16,5 \\
\hline 65 & E39 / M56 & E-AGA / M-CGC & 67 & 5 & 6,9 \\
\hline 66 & E39 / M58 * & E-AGA / M-CGT & 34 & 13 & 27,6 \\
\hline 67 & E39 / M59 * & E-AGA / M-CTA & 74 & 19 & 20,4 \\
\hline 68 & E39 / M60 & E-AGA / M-CTC & NA & NA & - \\
\hline 69 & E39 / M61 & E-AGA / M-CTG & 68 & 26 & 27,6 \\
\hline 70 & E39 / M62 & E-AGA / M-CTT & 61 & 11 & 15,3 \\
\hline 71 & E40 / M47 & E-AGC / M-CAA & 49 & 12 & 19,7 \\
\hline 72 & E40 / M48 & E-AGC / M-CAC & 45 & 9 & 16,7 \\
\hline 73 & E40 / M49 & E-AGC / M-CAG & 52 & 11 & 17,4 \\
\hline 74 & E40 / M50 & E-AGC / M-CAT & 45 & 7 & 13,4 \\
\hline 75 & E40 / M56 & E-AGC / M-CGC & 33 & 4 & 10,8 \\
\hline 76 & E40 / M58 & E-AGC / M-CGT & NA & NA & - \\
\hline 77 & E40 / M59 * & E-AGC / M-CTA & 40 & 10 & 20,0 \\
\hline 78 & E40 / M60 & E-AGC / M-CTC & 55 & 9 & 14,1 \\
\hline 79 & E40 / M61 & E-AGC / M-CTG & 50 & 9 & 15,2 \\
\hline 80 & $\mathrm{E} 40$ / M62 * & E-AGC / M-CTT & 41 & 17 & 29,3 \\
\hline 81 & E41 / M47 * & E-AGG / M-CAA & 53 & 8 & 13,1 \\
\hline 82 & $\mathrm{E} 41$ / M48 * & E-AGG / M-CAC & 42 & 17 & 28,8 \\
\hline 83 & E41 / M49 & E-AGG / M-CAG & 33 & 10 & 23,2 \\
\hline 84 & E41 / M50 & E-AGG / M-CAT & 48 & 13 & 21,3 \\
\hline 85 & E41 / M56 & E-AGG / M-CGC & 23 & 6 & 20,7 \\
\hline 86 & E41 / M58 & E-AGG / M-CGT & 35 & 7 & 16,7 \\
\hline 87 & E41 / M59 & E-AGG / M-CTA & 30 & 9 & 23,1 \\
\hline 88 & E41 / M60 & E-AGG / M-CTC & 32 & 10 & 23,8 \\
\hline 89 & E41 / M61 * & E-AGG / M-CTG & 41 & 19 & 31,7 \\
\hline 90 & E41 / M62 & E-AGG / M-CTT & 42 & 16 & 27,6 \\
\hline 91 & E44 / M47 & E-ACA / M-CAA & 37 & 6 & 13,9 \\
\hline 92 & $\mathrm{E} 44$ / M48 * & E-ACA / M-CAC & 48 & 14 & 22,6 \\
\hline 93 & E44 / M49 & E-ACA / M-CAG & 35 & 7 & 16,7 \\
\hline
\end{tabular}


Tabela 10. Resultado do screening das combinações de primers EcoRI + Msel para as linhagens genitoras Das21 e Das86

\begin{tabular}{cccccc}
\hline Número & Código Primer & Seqüência Primers & N $^{0}$ Amplif. & N $^{0}$ Polim. & $\%$ Polim. \\
\hline 94 & E44 / M50 * & E-ACA / M-CAT & 61 & 20 & 24,7 \\
95 & E44 / M56 & E-ACA / M-CGC & 30 & 5 & 14,3 \\
96 & E44 / M58 & E-ACA / M-CGT & 17 & 2 & 10,5 \\
97 & E44 / M59 & E-ACA / M-CTA & 36 & 14 & 28,0 \\
98 & E44 / M60 & E-ACA / M-CTC & 27 & 13 & 32,5 \\
99 & E44 / M61 & E-ACA / M-CTG & 29 & 17 & 36,9 \\
100 & E44 / M62 * & E-ACA / M-CTT & 58 & 28 & 32,6 \\
\hline \multirow{2}{*}{ Total Locos } & & & 5458 & 1353 & 24,8 \\
\hline
\end{tabular}

* combinações de primers EcoRI + Msel genotipados na população

NA indica não amplificado 
Tabela 13. Distribuição dos locos marcadores AFLPs nos grupos de ligação do mapa genético para as 17 combinações de primers EcoRI + Msel analisadas

\begin{tabular}{|c|c|c|c|c|c|c|c|c|c|c|c|}
\hline \multirow{2}{*}{$\begin{array}{l}\text { Combinação } \\
\text { EcoRI + Msel }\end{array}$} & \multicolumn{11}{|c|}{ Cromossomo } \\
\hline & 1 & 2 & 3 & 4 & 5 & 6 & 7 & 8 & 9 & 10 & $\mathrm{NC}^{*}$ \\
\hline AAA / CTG & & & 1 & 1 & & & 2 & & & & 3 \\
\hline AAC / CTC & & & 2 & 1 & 2 & & 1 & & 2 & & 5 \\
\hline AAC / CTG & & 2 & & 1 & & 1 & 2 & 1 & 1 & & 6 \\
\hline AAG / CTA & & & & 1 & & 3 & 1 & 2 & 2 & 1 & 6 \\
\hline ACC / CAC & & & & & 2 & & 1 & 1 & 1 & & 4 \\
\hline ACC / CTT & & & 2 & & & 3 & 2 & 1 & & 4 & 5 \\
\hline ACG / CAT & 1 & 1 & & 1 & 2 & & 2 & & & & 5 \\
\hline AGA / CGT & 1 & & 1 & & & & & & & & 2 \\
\hline AGA / CTA & & 3 & 1 & 1 & 2 & & & 1 & 1 & & 6 \\
\hline AGC / CTA & & 1 & & 3 & & & & & 1 & 1 & 4 \\
\hline AGC / CTT & 1 & 2 & & 2 & 3 & & & 1 & 2 & 1 & 7 \\
\hline AGG / CAA & & & & & & & & & & 1 & 1 \\
\hline AGG / CAC & 2 & 1 & 1 & 2 & & & 2 & & & 1 & 6 \\
\hline AGG / CTG & 1 & 1 & 2 & 2 & & & 1 & & & & 5 \\
\hline ACA / CAC & & 2 & & 1 & & 1 & 1 & & 2 & 1 & 6 \\
\hline ACA / CAT & 1 & 3 & 1 & 3 & 3 & 1 & & & & 1 & 7 \\
\hline ACA / CTT & & & 1 & 2 & 2 & & 4 & 2 & 1 & 1 & 7 \\
\hline Comb./Crom. & 6 & 9 & 9 & 13 & 7 & 5 & 11 & 7 & 9 & 9 & \\
\hline
\end{tabular}

* Número de cromossomos amostrados por combinação de primers AFLPs 


\section{REFERÊNCIAS BIBLIOGRÁFICAS}

AJMONE-MARSAN, P.; CASTIGLIONI, P.; FUSARI, F.; KUIPER, M.; MOTTO, $M$. Genetic diversity and its relationship to hybrid performance in maize as revealed by RFLP and AFLP markers. Theoretical and Applied Genetics, v.96, p.219-227, 1998.

AJMONE-MARSAN, P.; GORNI, C.; CHITTÓ, A.; RADAELLI, R.; VAN VIJK, R.; STAM, P.M. Identification of QTLs for grain yield and grain-related traits of maize (Zea mays L.) using AFLP map, different testers, and cofactor analysis. Theoretical and Applied Genetics, v.102, p.230-243, 2001.

ANDERSON, B.; NICHOLSON, R.L. Characterization of a laccase in the conidial mucilage of Colletotrichum graminicola. Mycologia, v.88, p.9961002, 1996.

BADU-APRAKU, B.; GRACEN, V.E.; BERGSTRON, G.C. A major gene for resistance stalk rot in maize. Phytopathology, v.77, n.6, p.957-959, 1987a.

BADU-APRAKU, B.; GRACEN, V.E.; BERGSTRON, G.C. Inheritance of resistance to anthracnose stalk rot and leaf blight in a maize inbread derived from a temperate by tropical germplasm combination. Maydica, v.32, p.221237, 1987b. 
BALMER, E.; PEREIRA, O.A.P. Doenças de milho. In: PATERNIANI, E.; VIÉGAS, G.P. Melhoramento e produção de milho. 2.ed. Campinas: Fundação Cargill, 1987. v.2, p.595-634.

BERGSTROM, G.C.; NICHOLSON, R.L. Effect of the Colletotrichum graminicola conidial matrix on the development of anthracnose seedling blight in maize. Fitopatologia Brasileira, v.8, p. 447-453, 1983.

BERGSTROM, G.C.; NICHOLSON, R.L. The biology of corn anthracnose: knowledge to exploit for improved management. Plant Disease, v.83, p.596608, 1999.

BORGES, M.F.; RESENDE, M.L.; VON PINHO, R.G. Inoculação artificial de colmos de milho em diferentes idades e concentrações de inóculo e sua relação com a expressão da resistência a Fusarium moniliforme. Fitopatologia Brasileira, v.26, n.4, p.715-720, 2001.

BRUNELLI, K.R. Mapeamento de genes de resistência a Puccinia polysora Underw em milho (Zea mays). Piracicaba, 2000. 70p. Dissertação (Mestrado) - Escola Superior de Agricultura "Luiz de Queiroz", Universidade de São Paulo.

BRUNELLI, K.R.; SILVA, H.P.; CAMARGO, L.E.A. Mapeamento de genes de resistência a Puccinia polysora em milho. Fitopatologia Brasileira, v.27, n.2, p.134-140, 2002.

BUBECK, D.M.; GOODMAN, M.M.; BEAVIS, W.D.; GRANTL, D. Quantitative trait loci controlling resistance to gray leaf spot in maize. Crop Science, v. 33, p.838-847, 1993. 
BYRNES, K.L.; CARROL, R.B. Fungi causing stalk rot of conventional-tillage and no-tillage corn in Delaware. Plant Disease, v.70, p.238, 1986.

CALLAWAY, M.B.; SMITH, M.E.; COFFMAN, W.R. Diallel analysis of resistance to anthracnose stalk rot in maize inbreds. Crop Science, v.30, p.335-337, 1990.

CALLAWAY, M.B.; SMITH, M.E.; COFFMAN, W.R. Effect of anthracnose stalk rot on grain yield and related traits of maize adapted to the northeastern United States. Canadian Journal of Plant Science, v.72, p.1031-1036, 1992.

CARSON, M.L.; HOOKER, A.L. Inheritance of resistance to anthracnose leaf blight in five inbred lines of corn. Phytopathology, v.71, p.488- 491, 1981.

CARSON, M.L.; HOOKER, A.L. Reciprocal translocation testcross analysis of genes for anthracnose stalk rot resistance in a corn inbred line. Phytopathology, v.72, p.175-177, 1982.

CASTIGLIONI, P.; AJMONE-MARSAN, P.; VAN WIJK, R.; MOTTO, M. AFLP markers in a molecular linkage map of maize: codominant scoring and linkage group distribuition. Theoretical and Applied Genetics, v.99, p.425431, 1999.

CHIN, E. C. L.; SENIOR, M. L.; SMITH, J. S. C. Maize simple repetitive DNA sequences: abundance and allele variation. Genome, v.39, p.866-873, 1996.

COCHRAN, W.G.; COX, G.M. Experimental design. 2.ed. New York: John Wiley \& Sons, 1966. 611p. 
COE, E.H.; HOISINGTON, D.A.; NEUFFER, M.G. Linkage map of corn (maize) (Zea mays L.). Maize Genetics Cooperation Newsletter, v.61, p.116-147, 1987.

COELHO, A.S.G. Considerações gerais sobre a análise de QTL's. In: PINHEIRO, J.B.; CARNEIRO, I.F. Análise de QTL no melhoramento de plantas. Goiânia: FUNAPE, 2000. p.1-20.

COÊLHO, R.M.S.; SILVA, H.P.; BRUNELLI, K.R.; CAMARGO, L.E.A. Controle genético da antracnose foliar em milho. Fitopatologia Brasileira, v.26, p.640-643, 2001.

CRESTE, S.; TULMANN NETO, A.; FIGUEIRA, A. Detection of single sequence repeat polymorfisms in denaturing polyacrylamide sequencing gels by silver stainig. Plant Molecular Biology Reporter, v.19, p.299-306, 2001.

CRUZ, C.D. Programa genes: aplicativo computacional em Genética e Estatística. Viçosa: UFV, 1997. 442p.

DALE, J.L. Corn anthracnose. Plant Disease Reporter, v.47, p.245-249, 1963.

DEL RIO, L.; ZÚNGIA, T. Efecto de algunas practicas culturales y fechas de recoleccion em la incidencia de Stenocarpella maydis (Berk). Sutton em maiz sembrado em dos sistemas de labranza. Ceiba,v.32, p.141-149, 1991.

DENTI, E.A.; REIS, E.M. Efeito da rotação de culturas, da monocultura e da densidade de plantas na incidência das podridões da base do colmo e no rendimento de grãos do milho. Fitopatologia Brasileira, v.26, n.3, p.635639, 2001. 
DENTI, E.A.; REIS, E.M. Levantamento de fungos associados às podridões do colmo e quantificação de danos em lavouras de milho do planalto médio gaúcho e dos campos gerais do Paraná. Fitopatologia Brasileira, v.28, n.6, p.585-590, 2003.

DIXON, R.A.; PAIVA, N.L. Stress-induced phenylpropanoid metabolism. Plant Cell, v.7, p.1085-1097, 1995.

DRAPER, J.M.; SMITH, H. Applied regression analysis. 2.ed. New York: John Wiley \& Sons, 1981. 70p.

DUBLE, C.M.; MELCHINGER, A.E.; KUNTZE, L.; STORK, A.; LÜBBERSTEDT, T. Molecular mapping and gene action of Scm1 and Scm2, two major QTL contributing to SCMV resistance in maize. Plant Breeding, v.119, p.299303, 2003.

EDWARDS, M.D.; STUBER, C.W.; WENDEL, J.F. Molecular-marker-facilitated investigations of quantitative trait loci in maize. Numbers, genomic distribution and typs of genes action. Genetics, v.116, p.113-125, 1987.

FANCELli, A.L.; DOURADO NETO, D. Produção de Milho. Guaíba: Agropecuária, 2000. 360p.

FERNANDES, F.T.; OLIVEIRA, E. Principais doenças da cultura do milho. Sete Lagoas: EMBRAPA, CNPMS. 1997. 80p. (EMBRAPA, CNPMS. Circular Técnica, 26)

FERREIRA, M. E.; GATTAPAGLIA, D. Introdução ao uso de marcadores moleculares em análise genética. 2.ed. Brasília: EMBRAPA, CENARGEN, 1995. 220p. 
FREYMARK, P.J.; LEE, M.; MARTINSON, C.A.; WOODMAN, W.L. Molecularmarker-facilited investigation of host-plant response to Exserohilum turcicum in maize (Zea mays L.). Theoretical and Applied Genetics, v.88, p.305313, 1994.

GATCH, E.W.; MUNKVOLD, G.P. Fungal species composition in maize stalks in relation to European corn borer injury and transgenic insect protection. Plant Disease, v.86, p.1156-1162, 2002.

GEORGE, M.L.C.; PRASANNA, B.M.; RATHORE, R.S.; SETTY, T.A.S.; KASIM, F.; AZRAI, M.; VASAL, S.; BALLA, O.; HAUTEA, D.; CANAMA, A.; REGALADO, E.; VARGAS, M.; KHAIRALLAH, M.; JEFFERS, D.; HOISINGTON, D. Identitication of QTLs conferring resistance to downy mildews of maize in Asia. Theoretical and Applied Genetics, v.107, p.544551, 2003.

GILBERTSON, R.L.; BROWN, W.M.Jr.; RUPPEL, E.G. Prevalence and virulence of Fusarium spp. associated with stalk rot of corn in Colorado. Plant Disease, v.69, p.1065-1068, 1985.

GOMES, F.P. Curso de estatística experimental. São Paulo: Livraria Nobel, 1990. 430p.

GRANER, A.; LUDWIG, W.F.; MELCHINGER, A.E. Relationships among European barley germplasm: II. Compararison of RFLP and pedigree data. Crop Science, v.34, p.1199-1205, 1994.

HALEY, C.S.; KNOTT, S.A. A simple regression method for mapping quantitative trait loci in line crosses using flanking markers. Heredity, v.69, p.315-324, 1992. 
HALLAUER, A.R.; MIRANDA FILHO, J.B. Quantitative Genetics in Maize Breeding. 2. ed. Ames: Iowa State University Press, 1988. 468p.

HAMMERSCHIMIDT, R.; NICHOLSON, R.L. Resistance of maize to anthracnose: Effect of light intensity on lesion development. Phytopathology, v.67, p.247-250, 1977.

HOISINGTON, D.; KHAIRALLAH, M.; GONZÄLEZ DE LEON, D. Laboratory protocols: CIMMYT applied molecular genetics laboratory. 2.ed. México: CIMMYT, 1994. 51p.

HOLLAND, J.B.; UHR, D.V.; JEFFERS, D.; GOODMAN, M.M. Inheritance of resistance to southern corn rust in tropical-by-corn-belt maize populations. Theoretical and Applieds Genetics, v.96, p.232-241, 1998.

HOLTON, T.A.; CORNISH, E.C. Genetics and biochemistry of anthocyanin biosynthesis. Plant Cell, v,7, p.1071-1083, 1995.

HYNE, V.; KEARSEY, M.J. QTL analysis: further uses of 'marker regression'. Theoretical and Applied Genetics, v.91, p.471-476, 1995.

JANSEN, R.C. Interval mapping of multiple quantitative trait loci. Genetics, v.135, p.205-211, 1993.

JANSEN, R.C.; STAM, P. High resolution of quantitative trait into multiple loci via interval mapping. Genetics, v.136, p.1447-1455, 1994.

JARVIS, J.L.; CLARK, R.L.; GUTHRIE, W.D.; BERRY, E.C.; RUSSEL, W.A. The relationship between second generation European corn borers and stalk rot fungi in maize hybrids. Maydica, v.24, p.247-263, 1984. 
JUNG, M.; WELDEKIDAN, T.; SCHAFF, D.; PATERSON, A.; TINGEY, S.; HAWK, J. Generation-means analysis and quantitative trait locus mapping of anthracnose stalk rot genes in maize. Theoretical and Applied Genetics, v.89, p.413-418, 1994.

KEARSEY, M.J.; HYNE, V. QTL analysis: a multiple 'marker regression' approach. Theoretical and Applied Genetics, v. ,p.698-702, 1994.

KEIM, P.; BEAVIS, W.; SCHUPP, J.; FREESTONE, R. Evaluation of soybean RFLP marker diversity in adapted germoplasm. Theoretical and Applied Genetics, v.83, p.205-212, 1992.

KELLER, N.P.; BERGSTROM, G.C. Developmental predisposition of maize to anthracnose stalk rot. Plant Disease, v.72, p.977-980, 1988.

KELLER, N.P.; BERGSTROM, G.C.; CARRUTHERS, R.I. Potential yield reductions in maize associated with an anthracnose / European corn borer pest complex in New York. Phytopathology, v.6, p.586-589, 1986.

KERNS, M.R.; DUDLEY, J,W,; RUFENER, G.K. QTL for resistance to common rust and smut in maize. Maydica, v.44, p.37-45, 1999.

KOMMEDAHL, T.; WINDELS, C.E.; STUCKER, R.W. Occurrence of Fusarium species in roots and stalks of symptomless corn plants during the growing season. Phytopathology, v.69, p.961-966, 1979.

LANDER, E.S.; BOTSTEIN, D. Mapping Mendelian factors underlying quantitative traits using RFLP linkage maps. Genetics, v.1, p.174-181, 1989. 
LANDER, E.S.; GREEN, P.; ABRAHAMSON, J.; BARLOW, A.; DALY, M.J.; LINCOLN, E.E.; NEWBURG, L. Mapmaker: an interactive computer package for constructing primary genetic linkage maps of experimental and natural populations. Genomics, v.1, p.174-181, 1987.

LANZA, L.L.B.; SOUZA Jr., C.L.; OTTOBONI, L.M.M.; VIEIRA, M.L.C.; SOUZA, A.P. Genetic distance of inbred lines and prediction of maize single-cross performance using RAPD markers. Theoretical and Applied Genetics, v.94, p.1023-1030, 1999.

LEONARD, K.J.; THOMPSON, D.L. Corn stalk rot fungi in North Carolina. Plant Disease Reporter, v.53, p.718-720, 1969.

LIM, S.M.; WHITE, D.G. Estimates of heterosis and combining ability for resistance of mayze to Colletotrichum graminicola. Phytopathology, v.68, p.1336-1342, 1978.

LIPPS, P.E. Spread of corn anthracnose from surface residues in continuous corn and corn-soybean rotation plots. Ecology and Epidemiology, v.78, n.6, p.756-761, 1988.

LITT, M.; LUTY, J.A. A hipervariable microssatellite revealed by in vitro amplification of a dinucleotide repeat within the cardiac muscle actin gene. American Journal of Human Genetic, v.44, p.398-401, 1989.

LIU, B.H. Statistical genomics. Linkage, mapping and QTL analysis. Boca Raton: CRC Press, 1998. 
LOPES, M.T.G. Mapeamento de genes de resistência a mancha de Phaeosphaeria em milho. Piracicaba, 2003. 117p. Tese (Doutorado) Escola Superior de Agricultura "Luiz de Queiroz", Universidade de São Paulo.

LÜBBERSTEDT, T.; KLEIN, D.; MELCHINGER, A.E. Comparative quantitative trait loci mapping of partial resistance to Puccinia sorghi across four populations of european flint maize. Phytopathology, v.88, n.2, p.13241329, 1998.

LYNCH, M.; WALSH, B. Genetics and analysis of quantitative traits. Sunderland: Sinauer Associates, 1998. 980p.

MACMULLEN, M.D.; SIMCOX, K.D. Genomic organization of disease and insect resistance genes in maize. Molecular Plant Microbe Interactions, v.8, p.811-815, 1995.

MAGALHÃES, P.C.; DURÃES, F.O.M.; PAIVA, E. Fisiologia da planta de milho. Sete Lagoas: EMBRAPA, CNPMS, 1995. 27p. (EMBRAPA, CNPMS. Circular Técnica, 20).

MARTINEZ, O.; CURNOW, R.N. Estimation the locations and the sizes of the effects of quantitative trait loci using flanking markers. Theoretical and Applied Genetics, v.85, p.480-488, 1992.

MATHER, K. Measurement of linkage in heredity. London: Methuen, 1938. $129 p$.

MATHER, K.; JINKS, J.L. Biometrical genetics. Ithaca: Cornell University Press, 1971. 382p. 
MELCHINGER, A.E.; KUNTZE, L.; GUMBER, R.K.; LÜBBERSTEDT, T.; FUCHS, E. Genetic basis of resistance to sugarcane mosaic virus in European maize germplasm. Theoretical and Applied Genetics, v.96, p.1151-1161, 1998.

MESSIAEN, C.M.; LAFON, R.; MOLCOT, P. Necroses de racines, pourritures de tiges et verse parasitaire du mais. Annales des Epiphyties, v.9, p.441473, 1959.

MICHELMORE, R.W.; PARAN, I.; KESSELI, R.V. Identification of markers linked to disease resistance genes by bulked segregant analysis: a rapid method to detect markers in specific genomic regions using segregating populations. Proceedings of the National Academy of Science of the United States of America, v.88, p.9828-9832, 1991.

MING, R.; BREWBAKER, J.L.; MOON, H.G.; MUSKET, T.A.; HOLLEY, R.N.; PATAKY, J.K.; McMULLEN, M.D. Identification of RFLP markers linked to a major gene, sw1, conferring resistance to stewart's wilt in maize. Maydica, v.44, p.319-323, 1999.

MIRANDA FILHO, J.B. Quantitative analysis of a cross between populations and their derived generations. Revista Brasileira Genética, v.14, p.547561, 1991.

MORELLO, R.M.S.C. Resistência em milho (Zea mays L.) a Colletotrichum graminicola (Ces.) Wils. Piracicaba, 2000. 94p. Tese (Doutorado) - Escola Superior de Agricultura "Luiz de Queiroz", Universidade de São Paulo.

MORGAN, O.D.; KRANTIZES, J. Observations of Colletotrichum graminicola on T corn and blends in Maryland. Plant Disease Reporter, v.55, p.755, 1967. 
MORGANTE, M.; OLIVIERI, A.M. PCR-amplifield microssatellites as markers in plant genetics. The Plant Journal, v.3, p.175-182, 1993.

MÜELLER, U.G.; WOLFENBARGER, L.L. AFLP genotiping and fingerprinting. Trends in Ecology \& Evolution, v.14, n.10, p.389-394, 1999.

MUIMBA-KANKOLONGO, A.; BERGSTROM, G.C. Transitory wound predisposition of maize to anthracnose stalk rot. Canadian Journal of Plant Pathology, v.12, p.1-10, 1990.

MUIMBA-KANKOLONGO, A.; BERGSTROM, G.C. Wound predisposition of maize to anthracnose stalk rot as affected by internode position and inoculum concentration of Colletotrichum graminicola. Plant Disease, v.76, p.188-195, 1992.

NAYLOR, D.V.; LEONARD, K.J. Survival of Colletotrichum graminicola in infected corn stalks in North Carolina. Plant Disease Reporter, v.61, p.382383, 1977.

NAZARENO, N.R.X. Avaliação de perdas por podridão do colmo em milho (Zeae mays) no Estado do Paraná. Fitopatologia Brasileira, v.14, p.82-84, 1989.

NILCHOLSON, R.L.; HAMMERSCHMIDT, R. Phenolic compounds and their role in disease resistance. Annual Review of Phytopathology, v.30, p.369389, 1992.

NILCHOLSON, R.L.; MORAES, W.B.C. Survival of Colletotrichum graminicola: importance of the spore matrix. Phytopathology, v.70, p.255-261, 1980. 
NILCHOLSON, R.L.; WARREN H.L. Criteria for evaluation of resistance to maize anthracnose. Phytopathology, v.66, p.86-90, 1976.

OGLIARI, J. B. Identificação e localização de um gene de resistência de milho a Exserohilum turcicum (Pass.) Leonard \& Suggs, através do uso de marcadores moleculares microssatálites. Piracicaba, 1999. 114p. Tese (Doutorado) - Escola Superior de Agricultura "Luiz de Queiroz", Universidade de São Paulo.

OGLIARI, J.B.; BOSCARIOL, R.L.; CAMARGO, L.E.A. Optimization of PCR amplification maize microsatélites loci. Genetic and Molecular Biology, v.23, p.395-398, 2000.

PASCHOLATI, S.F.; DEISING, H.; LEITE, B.; ANDERSON, D.; NICHOLSON, R.L. Cutinase and non-specific esterase activities in the conidial mucilage of Colletotrichum graminicola. Physiological Molecular Plant Pathology, v.42, p.37-51, 1993.

PATERNIANI, M.E.A.G.Z.; SAWAZAKI, E.; DUDIENAS, C.; DUARTE, A.P.; GALLO, P.B. Diallel crosses among maize lines with emphasis on resistance to foliar diseases. Genetics and Molecular Biology, v.23, n.2, p.381-385, 2000.

PĖ, M.E.; GIANFRANCESCHI, L.; TARAMINO, G.; TARCHINI, R.; ANGELINI, P.; DANI, M.; BINELLI, G. Mapping quantitative trait loci (QTL) for resistance to Gibberella zeae infection in maize. Molecular General Genetics, v.241, p.11-16, 1993. 
PEJIC, I.; AJMONE-MARSAN, P.; MORGANTE, M.; KOZUMPLICK, V.; CASTIGLIONI, P.; TARAMINO, G.; MOTTO, M. Comparative análisis of genetic similarity among maize inbred lines detected by RFLPS, RAPDs, SSRs, and AFLPs. Theoretical and Applied Genetics, v.97, p.1248-1255, 1998.

PEREIRA, O.A.P. Herança da resistência à podridão do colmo em milho (Zea mays L.) causada por Colletotrichum graminicola (Ces.) Wils. Piracicaba, 1983. 115p. Tese (Doutorado), Escola Superior de Agricultura "Luiz de Queiroz", Universidade de São Paulo.

PEREIRA, O.A.P.; BALMER, E.; MIRANDA FILHO, J.B. Inheritance of resistance to stalk rot, caused by Colletotrichum_graminicola (Ces.) Wills, in maize (Zea mays L.). Revista Brasileira Genética, v.12, p.53-65, 1989.

PEREIRA, O.A.P.; PEREIRA, W.S.P. Estudo de Diplodia zeae (Shw) Lev. e Fusarium moniliforme Sheld. em colmo de milho. Summa Phytopathologica, v.2, p.165-171, 1976.

PERKINS, J.M.; HOOKER, A.L. Effects of anthracnose stalk rot on corn yields in Illinois. Plant Disease Reporter, v.63, p.26-31, 1979.

PONELEIT, C.G.; POLITIS, D.J.; WEELER, H. Resistance to corn anthracnose. Crop Science, v.12, p.875-876, 1972.

PONTES, M.F.C. Características fisiológicas e morfológicas de Colletotrichum graminicola (Ces) Wils. e avaliação de fontes de resistência em milho (Zea mays L.). Recife, 1987. 82p. Dissertação (Mestrado), Universidade Federal Rural de Pernambuco. 
REIS, E.M.; CASA, R.T. Manual de identificação e controle de doenças de milho. Passo Fundo: Aldeia Norte, 1996. 78p.

SAGHAI MAROOF, M.A.; YUE, Y.G.; XIANG, Z.X.; STROMBERG, E.L.; RUFENER, G.K. Identification of quantitative trait loci controlling resistance to gray leaf spot disease in maize. Theoretical and Applied Genetics, v.93, p.539-546, 1996.

SANTOS, C.; REETZ, E.; CORRÊA, S.; BELING, R.R.; KIST, B.B. Anuário brasileiro do milho 2003. Santa Cruz: Gazeta Santa Cruz, 2003. 136p.

SAS INSTITUTE INC (Cary, NC). SAS System. Cary, 1993. 18v.

SCHALL, R.A.; NICHOLSON, R.L.; WARREN, H.L. Influence of light on maize anthracnose in the greenhouse. Phytopathology, v.70, p.1023-1026, 1980.

SENIOR, M.L.; CHIN, E.; AUSTIN, D.; LEE, M.; SMITH, S. Mapping simple sequence repeats in maize. Maize Newsletter, v.70, p.50-54, 1996.

SHURTLEFF, M.C. (Ed.). A compendium of corn disease. Saint Paul: The American Phytopathological Society, 1980. 64p.

SILVA, H.P. Incidência de doenças fúngicas na "safrinha". In: SEMINÁRIO SOBRE A CULTURA DO MILHO "SAFRINHA", 4., Campinas, 1997. Anais. Campinas: IAC/CDV, 1997. p.81-86.

SILVA, H.P. Análise genética da resistência a Puccinia polyssora Underw em milho (Zea mays L.). Piracicaba, 2001. 87p. Tese (Doutorado) - Escola Superior de Agricultura "Luiz de Queiroz", Universidade de São Paulo. 
SILVEIRA, A.P.; FIGUEIREDO, M.F.; CRUZ, B.P. Ocorrência de antracnose do milho no Estado de São Paulo. O Biológico, v.31, p.192-194, 1965.

SLOCUM, M.K.; FIGDORE, S.S.; KENNARD, W.C.; SUZUKI, J.Y.; OSBORN, T.C. Linkage arrangement of restriction fragment length polmorphism loci in Brassica oleracea. Theoretical and Applied Genetics, v.80, p.57-64, 1990.

SMITH, D.R. Yield reduction in dent corn caused by Colletotrichum graminicola. Plant Disease Reporter, v.60, n.11, p.967-970, 1976.

SUTTON, B.C. The coelomycetes. New York: Academic Press, 1980. 696p.

TANKSLEY, S. D. Mapping polygenes. Annual Review of Genetics, v.27, p.205-233, 1993.

TOMAN, J.R.; WHITE, D.J. Inheritance of resistance to stalk rot of corn. Phytopathology, v.83, p.981-986, 1993.

VAN DER VOORT, J.N.A.M., VAN ECK, H.J., VAN ZANDVOORT, P.M., OVERMARS, H., HELDER, J., BAKKER, J. Linkage analysis by genotyping of sibling populations: A genetic map for the potato cyst nematode constructed using a "pseudo- $F_{2}$ " mapping strategy. Molecular and General Genetics, v.261, n.6, p.1021-1031, 1999.

VOS, P., HOGERS, R., BLEEKER, M., REIJANS, M., VAN DE LEE, T., HORNES, M., FRIJTERS, A., POT, J., PELEMAN, J., KUIPER, M., ZABEAU, M. AFLP: a new technique for DNA fingerprinting. Nucleic Acids Research, v.23. n.21, p.4407-4414, 1995. 
VUYLSTEKE, M.; MANK, R.; ANTONISE, R.; BASTIAANS, E.; SENIOR, M.L.; STUBER, C.W.; MELCHINGER, A.E.; LUBBERSTEDT, T.; XIA, X.C.; STAM, P.; ZABEAU, M.; KUIPER, M. AFLP: two hight-density AFLP linkage maps of Zea mays L.: analysis of distribuition of AFLP markers. Theoretical and Applied Genetics, v.6, p.921-935, 1999.

WANG, D.L.; ZHU, J.; LI, Z.K.; PATERSON, A.H. Mapping QTLs with epistatic effects and QTL $x$ environment interactions by mixed linear model approaches. Theoretical and Applied Genetics, v.99, p.1255-1264, 1999.

WARREN, H.L. Survival of Colletotrichum graminicola in corn kernels. Phytopathology, v.67, p.160-162, 1977.

WARREN, H.L.; NICHOLSON, R.L.; ULLSTRUP, A.J.; SHARVELLE, E.G. Observations of Colletotrichum graminicola on sweet corn in Indiana. Plant Disease Reporter, v.57, p.143-144, 1973.

WELDEKIDAN, T.; HAWK, J.A. Inheritance of anthracnose stalk rot resistance in maize. Maydica, v.38, p.189-192, 1993.

WHEELER, H.; POLITIS, D.J.; PONELEIT, C.G. Pathogenicity, host range, and distribution of Colletotrichum graminicola on corn. Phytopathology, v.64, p.293-296, 1974.

WHITE, D.G.; YANNEY, J.; NATTI, T.A. Anthracnose stalk rot. Proceedings of the thirty-fourth annual corn and sorghum research conference. American Seed Trade Association, p.1-15, 1979. 
WILLIAMS, J.G.; KUBELIK, A.R.; LIVAK, K.J.; RAFALSKI, L.A.; TINGEY, S.V. DNA polymorphism amplified by arbitrary primers are useful as genetic markers. Nucleic Acids Research, v.18, p.6531-6535, 1990.

WILLIAMS, L.E.; WILLIS, G.M. Disease of corn caused by Colletotrichum graminicola. Phytopathology, v.53, p.364-365, 1963.

WU, W.R.; LI, W.M. A new approach for mapping quantitative trait loci using complete genetic marker linkage maps. Theoretical and Applied Genetics, v.89, p.535-539, 1994.

WU, W.R.; LI, W.M. Model fitting and model testing in the method of joint mapping of quantitative trait loci. Theoretical and Applied Genetics, v.92, p.477-482, 1996.

XU, M.L., MELCHINGER, A.E., XIA, X.C., LUBBERSTEDT, T. High-resolution mapping of loci conferring resistance to sugarcane mosaic virus in maize using RFLP, SSR and AFLP markers. Molecular and General Genetics, v.261, n.3, p.574-581, 1999.

YUAN, L.; DUBLE, C.M.; MELCHINGER, A.E.; UTZ, H.F.; LÜBBERSTEDT, T. Clustering of QTL conferring SCMV resistance in maize. Maydica, v.48, p.55-62, 2003.

ZENG, Z.B. Theoretical basis for separation of multiple linked gene effect in mapping quantitative trait loci. Proceedings of the National Academy of Sciences of the United States of America, v. 90, p.10972-10976, 1993.

ZENG, Z.B. Precision mapping of quantitative trait loci. Genetics, v.136, n.9, p.1457-1468, 1994. 
ZUBER, M.S.; AINSWORTH, T.C.; BLANCO, M.H.; DARRAH, L.L. Effect of anthracnose leaf blight on stalk rind strength and yield in $F_{1}$ single crosses in maize. Plant Disease, v.65, p.719-722, 1981. 